Universidade de São Paulo

Escola de Comunicações e Artes

Departamento de Artes Cênicas

EDGAR MANUEL VALADEZ VALADEZ

\title{
EL ACTOR EN VUELO
}

- La función del entrenamiento acrobático en la formación de actores

y actrices en el Centro Universitario de Teatro (CUT) / UNAM -

D i s s e r t a çã o a prese n t a d a ao Departamento de Artes Cênicas da Escola de Comunicações e Artes da Universidade de São Paulo, dentro do Programa Mestrado Interinstitucional (MINTER) CAC/ECA-CUT/UNAM para obtenção do título de Mestre em Artes Cênicas 
Autorizo la reproducción y difusión total o parcial de este trabajo, por cualquier medio convencional o electrónico, con fines de estudio e investigación, siempre que se mencione la fuente.

Catalogação na Publicação

Serviço de Biblioteca e Documentação

Escola de Comunicações e Artes da Universidade de São Paulo

Dados inseridos pelo(a) autor(a)

Valadez, Edgar Manuel Valadez

EL ACTOR EN VUELO: - La función del entrenamiento

acrobático en la formación de actores y actrices en el

Centro Universitario de Teatro (CUT) / UNAM - / Edgar

Manuel Valadez Valadez ; orientadora, Alice Kiyomi Yagyu. --

São Paulo, 2020.

115 p.: il. + DVD.

Dissertação (Mestrado) - Programa de Pós-Graduação em Artes Cênicas - Escola de Comunicações e Artes / Universidade de São Paulo.

Bibliografia

Versão original

1. Treinamento acrobático 2. Formação do ator 3. Atuação I. Yagyu, Alice Kiyomi II. Título.

CDD 21.ed. - 792 
Agradecimientos

A Manuel Valadez, Patricia Valadez, Sandra Valadez, Manuel J. Valadez y Fernando J. Valadez. Mi familia, que son el impulso que me mueve a crecer como ser humano y a seguir avanzando. Mis victorias son suyas también.

A los integrantes del grupo de teatro Festín Efímero, Guillermo, Héctor, Tania y José Juan. Mi segunda familia, me da el valor, me alienta y me exige ser mejor. Por quien siento una admiración profunda, y con los que tengo el orgullo de jugar sobre el escenario.

A la maestra Mayra Serbulo y los maestros Raúl Kaluriz, Dagoberto Gama y Gustavo Sánchez Parra. Porque me dieron las alas para volar, por la oportunidad de ser parte de su equipo de trabajo en el área de cuerpo y movimiento, sembrando en mí el amor y pasión por la docencia.

A Mario Espinosa Ricalde, director del CUT, por darme el arrojo, por confiar en mí y brindarme las oportunidades para salta al vacío, poder superarme, aprender y ser mejor maestro.

Al Centro Universitario de Teatro, mi hogar, la red de seguridad que me ha sostenido desde que llegue a él, que me ha hecho despegar como artista, pedagogo e investigador.

A mis exalumnas y exalumnos 2012-2017, a los que pude acompañar a través del miedo, el vértigo y la responsabilidad ser maestro principiante, que me brindaron su confianza para navegar y descubrir mi camino por los cielos de la pedagogía.

A mis alumnas y alumnos 2018-2021, que son mis maestros y maestras hoy día, que me dan la herramientas, la concentración, la relajación, la adrenalina y el coraje de ser mejor maestro, artista y ser humano con cada clase.

A mis futuras alumnas y alumnos, porque me seguirán desafiando como maestro, para seguir creciendo con sus enseñanzas.

A Pamela Meraz, por siempre estar ahí en los momentos más obscuros y en los más brillantes, ser mí guía, mi motivadora, mi cómplice, mi ayuda para volar alto.

A mis amigas, amigos y amores, por siempre estar ahí para darme fuerza y enderezar el trayecto, detonarme, energizarme, compartir y recordarme la belleza.

A mis maestros y maestras, porque una pequeña parte de ustedes vive en mí, gracias a su apoyo y soporte soy quien soy.

A mis maestros y colegas de la maestría, por brindarme equilibrio para avanzar por este difícil camino. 
A los profesores Eduardo Tassinari Coutinho y Verônica Gonçalves Veloso, por brindarme el soporte para el despegue y orientación del vuelo en mi examen de calificación.

A mi orientadora Alice Kiyomi Yagyu. Por guiarme en el camino de la investigación, para mí inhóspito y aparentemente inexpugnable, hacerme seguir mi instinto, por ser paciente, amable, comprensiva y siempre hacer que cuestione mis pensamientos. Si ella este salto mortal no podría concretarse.

A mí, por decidirme perder el miedo, confiar, tenerme paciencia, levantarme de las caídas, generar la energía necesaria para continuar, vencer la frustración, esforzarme a pesar de mis carencias y no rendirme nunca. El orgullo que siento es inefable. 
Resumen

Investigación de la función del entrenamiento físico para los estudiantes que se intentan profesionalizar como actor o actriz en Centro Universitario de Teatro - CUT, basándose en disciplinas como el acondicionamiento físico y la acrobacia. Observación de cambios en los contenidos de las disciplinas, desde el programa de estudios del CUT, en 1974, el año de su fundación, hasta el presente. Examina aspectos de instrumentalización, ejecución y resolución de problemas relacionados con el rendimiento, metodología y aplicación de la técnica de la acrobacia en formación del actor. Así como la propuesta de nuevas perspectivas, objetivos y enfoques sobre la noción del cuerpo del estudiante, para de esta manera obtener herramientas que puedan usar en su quehacer artístico como actores y actrices en un futuro.

\section{Abstract}

This project aimed to investigate the function of physical training to students intending to professionalize as an actor or actress at the University Theatrer Center - CUT, based on disciplines such as physical conditioning and acrobatics. In observing changes in the contents of the disciplines, since the CUT study program in 1974 (the year of foundation) to the present, it examines aspects of Instrumentalization, execution and resolution of problems related to the performance, methodology and application of the acrobatic technique in actor's education. As well as the proposal of new perspectives, objectives and approaches on the notion of the student's body, in order to obtain tools that they can use in their artistic work as actors and actrecess in the future. 
INDICE

Introducción

El origen del vuelo de los alumnos y alumnas del CUT

.07

Capítulo 1

Antecedentes

1.1. Fundación del CUT. 15

1.2. El comienzo de una era acrobática....................................... 19

1.3. La leyenda de los estudiantes que volaban............................ 23

Capítulo 2

Buscando la expresividad en el vuelo, en el viento.

2.1. Una breve consideración del entrenamiento. 33

2.2. El poder de navegar en el aire 35

2.3. Jugar - Volar - Domesticar - Actuar. 37

Capítulo 3

Los estudiantes jugando a ser pájaros

3.1. El entrenamiento acrobático para el actor o actriz en formación. 44

3.2. El refuerzo negativo o el asesinato del aprendizaje 53

3.3. El salto mortal de alumno a maestro principiante. 56

3.4. Ejército, atletas y artistas 61 
3.5. Inspección de la tradición, el comienzo del conocimiento corporal..... 71

3.5.1. Artistas con entrenamiento físico en las venas................... 75

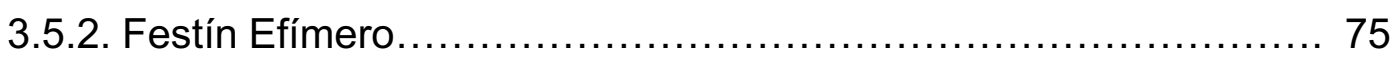

3.6 El pedagogo / investigador que surca los aires.................... 83

\section{Capítulo 4}

Los nuevos enfoques, objetivos y metodologías del entrenamiento físico en el CUT

4.1. Propuesta de nuevos planes de estudio........................ 90

4.2. La diversidad de los cuerpos................................... 95

Capítulo 5

El investigador en vuelo

$5.1 \quad$ Despegue y cielo abierto..............................................

Conclusiones

Primeras conclusiones de la investigación como:

Exalumno - Artista - Pedagogo - Investigador. 104

Bibliografía. 108 
Una vez hayas probado el vuelo, siempre caminarás por la Tierra con la vista mirando al cielo, porque ya has estado allí y allí deseas volver Leonardo da Vinci 


\section{INTRODUCCION}

\section{El origen del vuelo de alumnos y alumnas del CUT}

Analizando el origen de la impartición de clases de acondicionamiento físico y acrobacia en el Centro Universitario de Teatro de la UNAM, me tope que esto se remonta al año de 1974, cuando, en un montaje que se estaba desarrollando en el CUT, el director y profesor del centro Héctor Mendoza (1932-2010) necesitaba que sus estudiantes hicieran actos circenses y acrobacias en escena.

En los años setenta los maestros de acrobacia que se aventuraban a dar clases a los actores, venían del circo, de la carpa y del teatro de revista; no eran actores o directores precisamente, trabajaban con el objetivo de entrenar a los estudiantes para realizar las ejecuciones requeridas por el director. El maestro Héctor Mendoza decidió que esa preparación se quedara como base del entrenamiento físico para los actores y actrices en formación en aquellos años.

Ahora bien, como lo relatan las encuestas realizadas con miembros de la comunidad del CUT de generaciones pasadas, el entrenamiento constaba de ejecuciones gimnasticas en piso y en aparatos que les ayudaban a ganar fuerza muscular y confianza en el arrojo al realizar estos ejercicios.

Los maestros que impartían la clase no eran actores o directores, entonces esta materia no se perfilaba para ayudar al estudiante en su desempeño actoral en escena, sino solo al entrenamiento de su cuerpo, como si el estudiante fuera un deportista más que un artista.

Tener un cuerpo entrenado en disciplinas deportivas para la escena no está mal, al contrario si tenemos un cuerpo resistente, veloz, fuerte y ágil podremos tener la libertad de usarlo para crear y expresar infinidad de elementos escénicos. 
Pero entonces ¿Cuál es la razón o criterio de usar el entrenamiento gimnástico/acrobático como preparación corporal en el CUT?

Creo que con el paso del tiempo nadie se ha preguntado porque la clase de acondicionamiento físico y acrobacia en el CUT se imparte, o cuáles son sus beneficios para el actor y actriz en formación, si es que los hay.

Se asume que el entrenamiento físico en estas disciplinas ofrece herramientas para la escena, pero, como parte de la clase, es un descubrimiento que tenías que hacer por tu propia cuenta como estudiante, y no a todos les funcionaba este tipo de preparación.

En el CUT, que a lo largo de su historia contaba solo con maestros acróbatas y no con actores o actrices para dar estas clases, tuvo un enfoque más hacia las habilidades técnicas y deportivas, y no un enfoque actoral, que se podría usar también con las herramientas aprendidas: calentamientos, ejercicios expresivoactorales, preparación física de personaje, puestas en escena, entre otras, ya como profesional.

Parecía que los ejercicios se usaban solo cuando se necesitaban hacer actos circenses en obra de teatro, se utilizaban y proponían elementos acrobáticos simplemente porque se conocían y se dominaban.

Nunca o pocas veces se usaban para hacer analogías con la actuación, o como materiales para explorar emociones, resolver preguntas escénicas o del personaje.

Como dijo Grotowski "Si quisiera personas que hicieran actos circenses en escena, iría al circo a contratar cirqueros"1 (GROTOWSKI, 1992)

Con la incorporación de actores y actrices que ayudaban a los maestros acróbatas, que iniciaron las clases de acrobacia en el CUT, se pudo acceder un poco más a relacionar asignaturas como la acrobacia y la actuación. Ya no solo se

\footnotetext{
${ }^{1}$ GROTOWSKI, Jerzy. Los Juegos. Revista MASCARA. Escenologia A.C México DF, 1992.
} 
entrenaba el cuerpo, se empezaba a hablar de lo que intangiblemente provocaba dar un salto mortal, (miedo, sobreexcitación, vértigo, concentración, etc.) Y de la importancia del orden de las ideas al ejecutar un ejercicio, también de la memoria corporal, la importancia de estar entrenado para la escena, la resistencia respiratoria en favor de la escena, etc.

Con estos primeros acercamientos de la acrobacia impartida no solo por acróbatas, se daba un panorama más amplio de lo que podía ser este entrenamiento y para que nos podría ayudar como artistas.

Aun se carecía de investigación respecto al tema, ya que todo el conocimiento era empírico y los maestros acróbatas seguían las exigencias del entrenamiento y se limitaban a decir si un ejercicio estaba bien o mal ejecutado.

Las personas más afortunadas podían recurrir a ciertas sensaciones que les provocaban estos ejercicios al momento de estar en escena, al igual que descubrían como poder usarlo como herramienta, y no solo para fortalecer músculos o saber ejecutar un ejercicio gimnástico que tal vez nunca más usarían en el futuro.

Y los menos afortunados sufrían durante tres años por no poder ejecutar los ejercicios gimnásticos al no saber para que se hacia este tipo de entrenamiento.

Lo que se hizo con esta investigación fue descubrir y aplicar lo que se ha venido haciendo los últimos dos años en el CUT, poder brindar al alumnado una herramienta actoral que se basa en este tipo de entrenamiento y no solo exigirles la ejecución de ejercicios.

He investigado y me he especializado primero en el área física deportiva para poder conocer los procesos y metodologías del entrenamiento deportivo y poder después ver donde se cruzan con el entrenamiento actoral.

¿Qué podemos brindar en esta clase, además de una habilidad corporal para realizar entrenamiento físico? 
¿Sirve de algo este tipo de entrenamiento para la parte interpretativa de nuestro oficio o simplemente sirve para que se puedan ejecutar ejercicios acrobáticos en un montaje si un director lo pide?

En efecto, considero que un trabajo corporal complementa el trabajo actoral, también pienso que los procesos mentales que se tienen en un proceso de entrenamiento físico son de suma importancia para el desarrollo actoral.

Me vienen muchas palabras a la mente que usamos en clase como: arrojo, miedo, relajación, tensión, impulso, generación de energía, detonación, orden de ideas, multitareas, concentración, presencia, pausa, timing, conciencia, dominio, fuerza, apoyo, centro, movimiento, tolerancia a la frustración, resistencia, valor, dominio, respiración, etc.

Palabras que también me recuerdan mucho mis clases de actuación o utilizo en ensayos y puestas en escena.

Ahora creo que la tarea va dirigida a cómo hacer que se tome conciencia que todo lo que entrenamos en la ejecución de ejercicios de acondicionamiento físico y acrobacia nos es útil como herramienta a la hora de estar en escena, no solo cuando necesitamos ejecutar suertes acrobáticas.

Como dicho anteriormente, reflexionar sobre esta práctica hoy es importante, ya que de otra manera estamos instalados en un modo de dar las clases como se hacía hace 44 años.

En cuyo caso, se espera que el solo hecho de que se tomen las clases de acondicionamiento y acrobacia haga que el alumnado entienda el propósito de la clase en beneficio de su quehacer escénico, como si mágicamente cursar la materia los hiciera comprender o generar las herramientas para el hecho escénico.

$Y$ aunque con el tiempo se ha ido ganando terreno en este aspecto en las últimas décadas, considero que todavía estamos en el camino de entender y revisar cómo este tipo de entrenamientos beneficia al actor y a la actriz en formación del Centro Universitario de Teatro de la UNAM en la Ciudad de México en la actualidad. 
Espero con mi investigación cambiar el enfoque que los maestros acróbatas le dieron en un inicio a la materia. Con sus salidas de la institución en tiempos recientes, se pretendía conservar la disciplina y rigor de la clase, pero ya no se enfocado en al virtuosismo de la ejecución o al objetivo deportivo de la materia.

Ahora nos encaminamos a lograr que tanto alumnado como profesorado, puedan hacer los procesos mentales necesarios para aprovechar al máximo el entrenamiento físico, sin estar preocupados por la correcta o incorrecta ejecución de los ejercicios, si no por detectar como ayuda dentro del proceso de formación. Esos es lo que nos diferencia del entrenamiento deportivo; no buscamos la meta, buscamos los procesos.

No nos interesa ser más rápidos, o ir más alto, o ser más fuertes, "Citius, Altius, Fortius" palabras del barón Pierre de Coubertin en la inauguración de los primeros Juegos de la Edad Moderna, en 1896 en Atenas, las cuales son la meta de cualquier deportista de alto rendimiento y piedra angular del deporte de competición.

Para las actividades que hacemos en clase, dejaría a un lado las palabras del barón, las cambiaría por otras palabras en latín como "Ludos, conscientiam, cognitio, corporis" - Juego, conciencia, conocimiento corporal -, entre muchas otras que describirían mejor los objetivos que en realidad persigue esta materia.

Al revisar la información que existe sobre este tipo de entrenamiento en México, su evolución a través de los años en el quehacer artístico nacional, su influencia en las distintas escuelas profesionales de teatro, pero sobre todo en la historia del CUT, he podido analizar y comprender el papel de esta capacitación para proponer nuevas perspectivas a los actuales planes de trabajo del centro universitario de teatro de la UNAM.

Al haber sido alumno del CUT del 2007 al 2011 y al haber tomado estas clases durante tres años, recordé y analicé cómo fue mi paso por el aula, como fue la transición de ser alumno a maestro adjunto del 2012 al 2016, y después maestro titular de las mismas materias del 2018 a la fecha. 
De la misma manera que me hizo enfocarme también al trabajo que he hecho como artista con mi compañía de teatro Festín Efímero, respecto al trabajo de entrenamiento físico que usamos en nuestros montajes.

Para finalmente realizar un análisis de mi trabajo como investigador y así cerrar el ciclo de reflexión sobre el entrenamiento físico de alumno / pedagogo / artista / investigador, para hacer un compendio de todo este análisis y responder las preguntas que dio origen a esta investigación.

Para la presente investigación, utilicé los siguientes procedimientos:

- Entrevistas y pláticas con miembros de la comunidad del CUT.

- Entrevistas y pláticas con actores, actrices, directoras y directores.

- Revisión de prácticas, simulación y experimentación en el salón de clases con primer año en acondicionamiento físico y rítmico.

- Revisión de prácticas, simulación y experimentación en el salón de clases con segundo y tercer año en acrobacia.

- Revisión de prácticas con base en los montajes de titulación de cuarto año con ejercicios de acondicionamiento y acrobáticos.

- Consulta de documentación y de arquivos institucionales.

- Revisión de bibliografía. 
Tu salto es un segundo congelado, Que ni apresura el tiempo ni lo mata: Preso en su movimiento ensimismado Tu cuerpo de sí mismo se desata Ycae.

Octavio Paz 


\section{CAPITULO 1}

\section{Antecedentes}

¿Porque algunas tradiciones deberían transformarse o desaparecer?

De inicio, presento una cronología:

1962 Fundación del CUT - Centro Universitario de Teatro / UNAM.

1974 Inicio de la clase de acrobacia en el CUT.

1994 Inicio de la clase de acondicionamiento en el CUT.

1995 Primer cambio de paradigma en la clase.

2003 Primeros planes de estudios formales del CUT.

2007 Ingreso del alumno Edgar Valadez a los 25 años.

2011 Egreso.

2012 Inicio de Edgar Valadez como maestro.

2012 Primer montaje de Valadez como actor profesional y director "La ley del ranchero"

2014 Formación de la compañía Festín Efímero, a la que actualmente pertenece.

2016 Inicio de titularidad de la clase de acrobacia en el CUT y segundo cambio de paradigma en la clase.

2017 Especialidad en teoría y metodología del entrenamiento deportivo.

2020 Valadez continua activo como maestro del CUT. 


\subsection{Fundación del CUT (1962)}

El CUT - Centro Universitario de Teatro se fundó en 1962, por Héctor Azar, Jefe de la Sección de Teatro de la UNAM - Universidad Autónoma México, quien propuso la creación como continuación a los movimientos teatrales de vanguardia en México.

Evoluciono en 1973 para dar formación reglada a un centro de extensión perteneciente a la UNAM, el cual era público y ofrecía un diplomado con diversas clases, convirtiéndose en pocos años en uno de los principales centros de capacitación actoral del país.

En 1977, pasó por una reestructuración interna y amplía su ofrecimiento, con talleres de formación con Luis de Tavira (dramaturgo, director de teatro, ensayista y pedagogo y cofundador del CUT) y José Caballero (director de teatro, actor y pedagogo). En 1980 el CUT se trasladó a su sede actual en el Centro Cultural Universitario en la UNAM.

Por su trayectoria y ubicación en el contexto de la enseñanza del teatro mexicano, se destaca en la formación de miembros de la comunidad que desempeñan distintas tareas para el quehacer artístico. Ya desde su fundación el Centro ha sido dirigido por las figuras destacadas del teatro mexicano: Héctor Azar, Héctor Mendoza (Premio Nacional de Ciencias y Artes), Luis de Tavira (Premio Nacional de Ciencias y Artes), Ludwik Margules (Premio Nacional de Ciencias y Artes), José Caballero, Raúl Quintanilla, Raúl Zermeño, José Ramón Enríquez, Antonio Crestani y Mario Espinosa.

Refiriéndose a la formación de actores, el CUT, presenta sus objetivos y misión de la siguiente forma:

[...] como una sólida institución de enseñanza teatral que brinda a sus alumnos y alumnas los elementos que los forjarán para desempeñarse exitosamente, no sólo en un medio tan complejo, exigente y competitivo como lo es el teatro, sino en otros ámbitos relacionados con el quehacer escénico; 
[...] el estudiante conocerá el medio teatral mexicano y sus formas organizativas, y será un miembro activo de la comunidad teatral a la cual se integrará como un ser que posee un amplio registro creativo, organizativo y conceptual acerca de las diversas técnicas de interpretación, y es capaz de seguir desarrollándolo.

Manejará los distintos discursos y lenguajes estéticos contemporáneos, y será capaz de interpretar y crear personajes dentro de un amplio marco de posibilidades escénicas, teniendo como base el trabajo desarrollado a través de su formación actoral, siempre con la consciencia de analizar y reflexionar sobre sus procesos creativos.

El profesional del teatro formado con este plan de estudios, empleará las técnicas apropiadas para leer e interpretar una partitura musical, para llevar entrenamientos físicos de alto riesgo, realizar combate escénico, ejecutar e incluso diseñar una coreografía o una partitura corporal, manejar consolas de luces y diseñar iluminación, realizar acrobacia, cantar, y tendrá también nociones básicas para la dirección escénica o la dramaturgia.

Mantendrá una actitud crítica hacia su trabajo y su quehacer, asumiendo la responsabilidad de los contenidos y formas de su oficio. ${ }^{2}$

Hay muchas preguntas que surgen para esclarecer los orígenes de un entrenamiento de este tipo en una escuela de teatro. Ya que al pertenecer a una generación de más reciente egreso del CUT, desconocía como fue el proceso de formación y anexo de esta materia al plan de estudios. Entonces me pregunto:

¿Cómo funcionaba el CUT en sus inicios?

En entrevistas, con distintos integrantes de la comunidad del CUT, señalan que en sus inicios el CUT no funcionaba como una escuela donde se daban clases, si no como un tipo de laboratorio para montar piezas escénicas, donde dependiendo

${ }^{2}$ En www.cutunam.com.mx 
lo que necesitaba la obra en curso, se impartían clases, con el fin de enriquecer la puesta en escena.

Todo giraba en torno a la puesta en los diferentes años y los diferentes grupos, si la obra necesitaba que las personas cantaran se tenían clases de canto, si se necesitaba que los individuos bailaran se daban clases de baile, si se necesitaba explotar la expresividad se daban clases de danza, etc, con lo cual los actores y actrices ganaban herramientas además de experiencia enfocadas a montar un texto para su presentación.

¿Qué cambios ha habido de su fundación a la fecha?

Según los entrevistados, con el cambio de sede a la Universidad Nacional Autónoma de México y de directores responsables de las riendas del centro, se fue adoptando más el modelo escolarizado donde se tenía una tira de materias durante dos o tres años con distintas disciplinas y al final se volcaba todo ese conocimiento en montajes profesionales que se presentaban en los teatros de la Universidad.

Se podría decir que el CUT era un diplomado sin validez oficial, pero con la adhesión como licenciatura a la universidad en el 2016, se tuvieron que hacer ajustes en el número de materias, créditos, objetivos, planes de estudio, etc.

Con lo cual ahora se tiene un modelo totalmente universitario, con las virtudes y áreas de oportunidad que esto con lleva, pero tratando de conservar la calidad y disciplina que dio origen a ser conocido como una de las mejores escuelas de formación de actores y actrices en México.

¿Qué hacen sus egresados?

En las entrevistas antes mencionadas, se expresa que sus egresados mayormente por tener una preparación para las artes escénicas, pasan por los distintos escenarios nacionales, tanto como invitados de compañías o proyectos, así como con compañías formadas por generaciones o grupos formados durante su estancia en el CUT. También pueden participar de compañías de teatro independiente o la compañía nacional de teatro. 
Además suelen incursionar en otros medios actorales como el cine y la televisión, ya que las herramientas otorgadas durante sus estudios permiten desenvolverse bien en estos otros medios.

Algunas de las actividades no actorales más características en las que incursionan los egresados del CUT también son: dirección, escenografía, iluminación, producción, canto, danza, crítica, investigación, entre otras.

¿Cómo han cambiado sus objetivos, programas de estudio, etc.?

Acorde con las charlas y entrevistas a distintos conocedores de la historia del CUT, un principio este se manejaba como un centro cuyo propósito era preparar personas con distintas disciplinas que se impartían con base de que necesitaba el montaje que se estuviera haciendo.

Con el tiempo se escolarizo este modo de producción con la adhesión del centro a la universidad, pero básicamente se seguía el mismo formato ciertas clases que compartían con base en las necesidades del director que dirigía la obra en turno.

Más adelante se acogió una forma más académica, volviéndose un diplomado y centro de extensión de la universidad, con lo cual se acotaron el número de disciplinas, estandarizándolas y dividiéndolas por años, desembocando todo en uno o dos montajes finales donde se vertían todos los conocimientos de los años previos de clases.

Hoy en día al volverse una licenciatura se tuvo que entrar en el esquema de la universidad con cierto número de créditos por año y el recorte de materias obligatorias para pasar a un sistema de materias obligatorias y materias no obligatorias, además se anexo el sistema de titulación. 


\title{
1.2. El comienzo de una era acrobática (1974)
}

Tal como lo afirmaba Stanislavski en su libro El trabajo del actor sobre sí mismo:

\begin{abstract}
Desde hoy agregamos la acrobacia a nuestras actividades. Aunque esto pueda parecer extraño, es necesaria para el artista más en su empleo interior que en el exterior... la razón es que la acrobacia ayuda a desarrollar la cualidad de la decisión... Además, la acrobacia les prestará otro servicio: les ayudará a ser más ágiles, más eficientes físicamente, en la escena, cuando se levantan, al girar o correr, y en una variedad de movimientos rápidos y difíciles. (STANISLAVSKI, 2013)
\end{abstract}

En entrevista con el maestro Raúl Kaluriz, fundador de la clase de acrobacia en el CUT, en el año de 1974, este afirma que el director de aquel entonces, Héctor Mendoza, le tendió la invitación para formar parte de la planta docente para instruir al alumnado en las artes circenses y la acrobacia, ya que, como Mendoza explicaba, era una herramienta necesaria para el desarrollo motriz y mental de los estudiantes.

Kaluriz explica que Mendoza, director del CUT y maestro de actuación, quiso aplicar los estudios de Stanislavki acerca de la acrobacia como entrenamiento para los estudiantes; con lo cual se dedicó a entrenarlos y transitar por un entrenamiento acrobático en el año de 1974, que fue el año en que la clase de acrobacia se integró a los múltiples entrenamientos que se hacían en el CUT.

La urgencia de contar con un maestro acróbata venido del género mexicano de la carpa y el circo, que pudiera enseñar evoluciones acrobáticas fue uno de los principales motivos por el cual Mendoza recurrió esta clase de artista para cubrir esa necesidad.

\footnotetext{
${ }^{3}$ STANISLAVSKI, Konstantín. El trabajo del actor sobre sí mismo. México DF: Grupo Editorial Tomo, 2013.
} 
El maestro Kaluriz, aunque era un hombre de espectáculo, no era un actor o director de formación, lo cual provocaba que la enseñanza fuera meramente acrobática, pero rica en espectacularidad y muy vistosa para las puestas en escena.

Kaluriz era un show man, que podía enseñar acrobacia, malabarismo, clown, traga fuegos y un sin número de técnicas relacionadas con la espectacularidad.

La relación acrobacia-actuación corría por parte, en el mejor de los casos, por el maestro de actuación en turno o por el director, aunque otras veces no se daba esta relación y quedaba todo en un simple entrenamiento del cuerpo.

Se apeló a que era la persona más cercana a un artista que supiera ejecutar artes acrobáticas, por lo cual recurrir a un gimnasta o a un artista de circo se alejaría aún más del objetivo de enseñar acrobacia y se centraría más en la enseñar un deporte.

A pesar de las carencias como pedagogo e investigador, Kaluriz seguía siendo un hombre de escena y de espectáculos, lo cual podría dar cabida a una cierta conciencia de relacionar la clase con herramientas útiles para la escena.

Aunque fueran meramente ejecutorias, se hacía constante relación sobre la importancia de que se supiera acrobacia, para el maestro la importancia de un cuerpo expresivo y preparado radicaba en la correcta ejecución de ejercicios y eso podría llevar a adquirir intrínsecamente seguridad, energía y buen manejo del escenario.

Muchas veces esto se pensaba que se adquiría por el solo hecho de hacerlo, y no por un análisis pedagógico de los maestros en turno. En pocas palabras se decía que por el simple hecho de haber tomado la clase ya podías adquirir las herramientas que la acrobacia otorga, y tal vez sí, pero no en todos los casos.

Esto llevaba a que el examen de admisión al CUT fuera, hasta hace algunas décadas, una prueba donde los cuerpos de los aspirantes contaran ya con un historial que pudiera beneficiar a las clases corporales. 
Se dice que el examen propedéutico del CUT era, en aquellos tiempos, de mucha rudeza hacia los cuerpos, sobre todo en las áreas de actuación y cuerpo/movimiento, lo que en ese tiempo provocaba la deserción de muchos aspirantes que intentaban formar parte del Centro.

Por ejemplo, se sometía al cuerpo del aspirante a pruebas de velocidad en trote, resistencia a la fuerza, fuerza muscular, equilibrio precario, trabajo con el peso del compañero, entre otras.

Según palabras de ex integrantes del centro, que fueron entrevistados y cuestionados al respecto, mucha de la acrobacia vista en clase en la época de los setenta y ochenta, no era más que beneficiosa para las personas que contaban con un historial corporal previo a tomar las clases en el CUT, y para el resto, un cumulo de frustraciones por no poder realizar los ejercicios acrobáticos.

La pedagogía empleada por el maestro Kaluriz se centraba en ejecutar los ejercicios acrobáticos, explicar la mecánica de estos para después ser imitados y ejecutados por el estudiante, no existía una preparación previa para enfrentar los cuerpos a un trabajo deportivo de este tipo, el cual podía rayar en lo peligroso. Por suerte nunca hubo accidentes graves que lamentar, aunque si se incurría en muchas lesiones de ligamentos, musculares y óseas.

Los ejercicios a ejecutar en clase consistían en calentamientos articulares y estiramientos musculares, estos servían para preparar los cuerpos a enfrentarse a las maniobras mecánicas que requiere la acrobacia: impulsos, contra impulsos, inercia, tensión, etc. Ejecuciones en piso: rodadas, saltos, ingravidez, entre otros. Ejecuciones en aparatos gimnásticos: saltos de trapezoides, saltos en trampolín fijo y en cama elástica.

Estos ejercicios eran individuales, por parejas y en equipos. Al final de la clase se contaba con un mínimo entrenamiento de acondicionamiento, que consistía en ejercicios de fuerza muscular en brazos, piernas, torso, espalda y abdomen para poder auxiliar a las ejecuciones acrobáticas. 
Como no se contaba aun con las instalaciones adecuadas, este tipo de ejercicios se hacían en la explanada delantera y trasera del CUT, lo cual llevaba un riesgo mayor ya que se hacían sobre loza de cemento y no sobre duela.

También se llegaron a ejecutar ejercicios como saltar un coche VW beatle o ejercicios de traga fuegos, entre otros, que en la perspectiva de muchas personas que los ejecutaban, contribuían mucho al riesgo y poco al entrenamiento, se consideraban carentes pedagogía físico actoral.

Muchos estudiantes del CUT de 1974 en adelante pasaron por esta clase, algunos obteniendo conscientemente una herramienta a utilizar en su quehacer artístico y otros meramente tratando de pasar por la materia sin que esta les aportara nada más que una herramienta de posible ejecución escénica en caso de que algún director o proyecto necesitara de quien supiera hacer saltos, piruetas o rodadas.

En entrevista con un alumno de la generación 86-90 en la pregunta ¿Para qué te sirvió la clase de acrobacia? su respuesta fue: "Para poder hacer una rueda de carro en escena en un montaje".

Aquí podemos ver como para algunos individuos solo fue una mera herramienta de ejecución.

En cambio la respuesta de otro ex alumno y ex alumnas de la generación 9600 a la misma pregunta tuvo que ver más con la analogía que se hizo entre la preparación antes de salir a escena y la preparación de un salto mortal.

Aun así, como ya se mencionó, según la entrevistas realizadas, en aquellos años y hasta la fecha se dice que el alumnado del CUT contaba con algo diferente a los estudiantes de otras escuelas.

¿Puede el cuerpo adquirir inconscientemente ciertas herramientas con el entrenamiento acrobático que son semejantes a las herramientas que nos son útiles para actuar? Como el arrojo, rebasar límites, la voluntad, la decisión, la concentración, entre muchas otras. 
Ahora me pregunto ¿Qué hubiese pasado si se hubiera hecho un análisis profundo de este tipo de atributos que se adquieren con la acrobacia?

Se podría haber maximizado el potencial de los estudiantes o se entendería la acrobacia de otra manera, así como lo describe Borja Ruiz:

\begin{abstract}
En primer lugar, el entrenamiento del cuerpo resulta imprescindible para que éste responda a las exigencias generadas en el proceso de la vivencia interna y poder transmitir el mundo interior del personaje. (...) Stanislavski se valió de materias como la gimnasia, la acrobacia, la danza, el gesto, la esgrima o la lucha para obtener una disposición corporal idónea en el actor. A través de este tipo de ejercicios buscaba desarrollar un aparato físico "dinámico, flexible, expresivo y sensible". Además de ejercicios puramente físicos, estas disciplinas proveían a Stanislavski de elementos que se podían trasvasar a la esfera dramática del actor. Sirva como ejemplo la acrobacia, que no sólo implicaba el entrenamiento de movimientos agiles, veloces y de gran dificultad, sino que también desarrollaban una disposición mental necesaria (RUIZ 2008) ${ }^{4}$.
\end{abstract}

\title{
1.3. La leyenda de los estudiantes que volaban (1980 a 1994)
}

Ya para los años 80's el maestro Luis de Tavira, entonces director del CUT había plasmado en otras palabras la importancia de la clase de acrobacia:

"La acrobacia juega un papel importante en la preparación de un actor, no solo en el aspecto físico, sino también como entrenamiento de la voluntad y decisión, atributos que encontramos análogamente en la actuación."

Lo cual sumo para que se le diera más importancia a la materia en los años subsecuentes. Esto se vio con la llegada de otros maestros al área de cuerpo y movimiento, que al ser actores de profesión y expertos a su vez en el área corporal, pudieron darle un primer giro a la materia con un enfoque más pedagógico actoral.

\footnotetext{
${ }^{4}$ RUIZ, Borja. El arte del actor en el siglo XX. Artezblai SL, México DF, 2008.

${ }^{5}$ Programa de estudios CUT 1980, punto 6.1.6
} 
Esto contribuyo a visualizar algunos cambios necesarios para empezar a mezclar el trabajo acrobático y actoral.

Plan de estudios CUT 1980
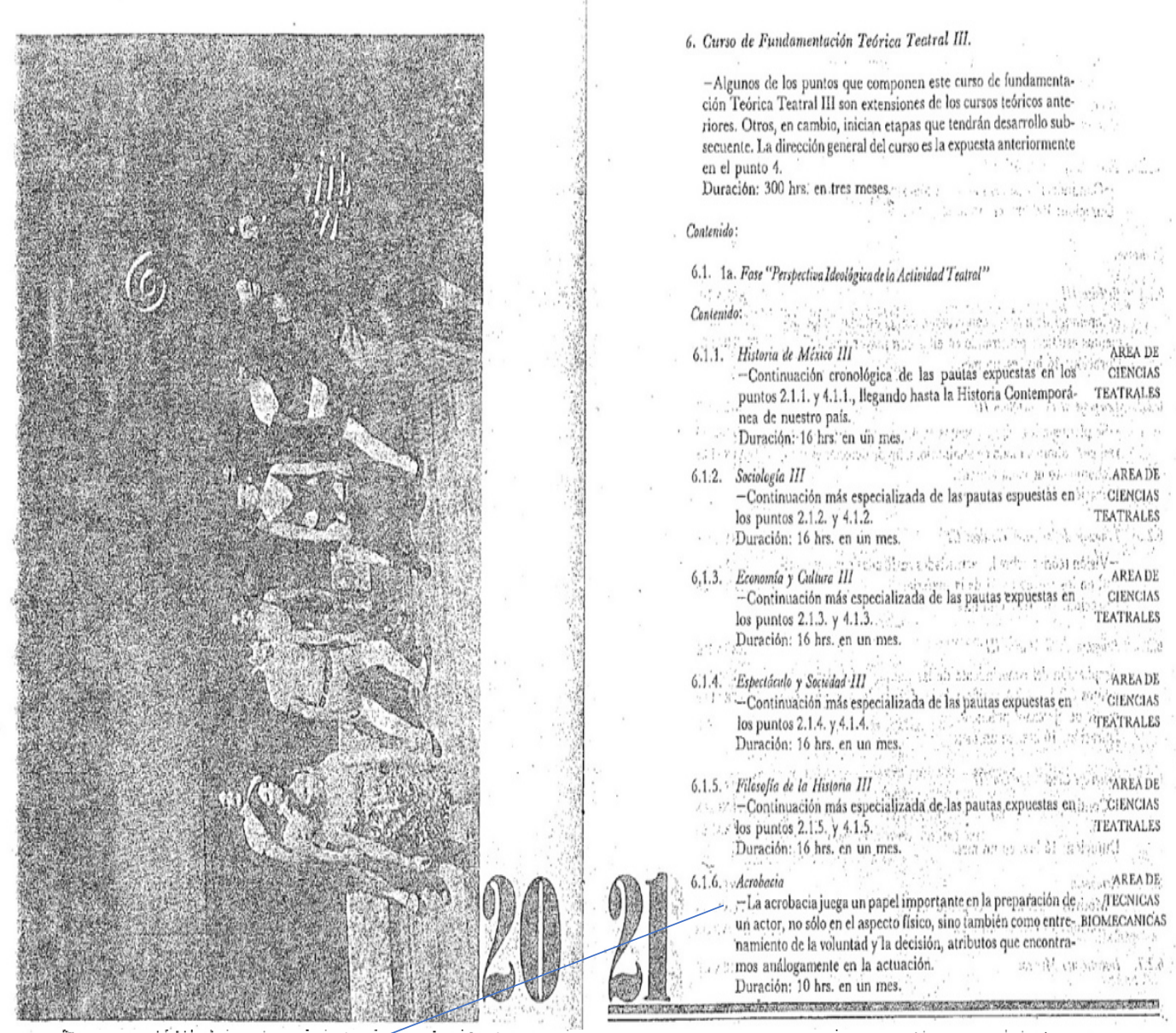

6.1.6. .Acrobacio

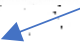

AREA DE:

- La acrobacia juega un papel importante en la preparación de le lECNICAS

ur actor, no sólo en el aspecto físico, sino también como entre- BIOMECANICAS namiento de la voluntad y la decisión atributos que encontra-

: $\operatorname{mos}$ análogamente en la actuación.

Duración: 10 hrs. en un mes.

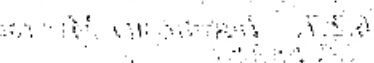

Gracias a la intervención del nuevo profesorado, en el año de 1988, se imparte la materia de acrobacia desde el segundo año.

Esto beneficio en que todo el material que se tenía que ver con anterioridad en un solo año, ahora se podría distribuir en dos, preparando los cuerpos para abordar la acrobacia con un poco más de herramientas físicas y mecánicas, que 
contaba con un entrenamiento de acondicionamiento más amplio hasta el repaso de los ejercicios de manera más extensa.

En esos años el reconocimiento de la escuela en cuanto al trabajo corporal y la calidad de los estudiantes que egresaban, iban creciendo.

La espectacularidad acrobática en escena de muchas obras, como la dirigida por el maestro Luis de Tavira, El alma buena de Szechuan, de Bertold Brecht, la cual pudo vivir más allá de los foros universitarios, realizar giras por muchos espacios en la ciudad de México y provincia, la cual provocaba que más aspirantes se interesara por entrar a la escuela, para poder llevar esta clase de entrenamiento y adquirir estas herramientas.

Esto pone los reflectores tanto en el CUT como en la clase de entrenamiento que se llevaba a cabo, ya que no se veía en montajes de otras escuelas y se apreciaba en muy pocas personas estas cualidades físicas.

Se empezó a tener repercusiones positivas para estudiantes del centro, ya que se sabía que contaban con un entrenamiento y disciplina que podía ser utilizada tanto instrumental como metafóricamente en una puesta en escena.

Con toda esta información y antecedentes me pregunto:

¿Cómo ha cambiado esta materia con el pasar de los años?

Con la llegada de la maestra Mayra Serbulo (Actriz y profesora) en 1994, se gestionó la inclusión de una materia que anteceda a la acrobacia. Se concluyó que se necesitaba preparar a los estudiantes antes de enfrentarlos a un entrenamiento acrobático, ya que abordar esta clase de entrenamiento de cero resultaba un trabajo muy pesado y tardado.

Además, el acondicionamiento físico que se hacía en clase no era suficiente para que el estudiante pudiera estar listo para enfrentar la acrobacia de modo efectivo y seguro. 
Las historias corporales de los estudiantes eran muy distintas; había desde quien había hecho deporte toda su vida, hasta quien nunca había jugado de niño o hecho alguna actividad física.

Así a mediados de la década de los noventas se contaba ya con una materia seriada por año, acondicionamiento físico y rítmico en primer año, acrobacia I en segundo año y acrobacia II en tercer año.

Con lo cual se preparaba y acondicionaba a las personas durante dos semestres para estar listo a realizar ejercicios acrobáticos sin riesgo a lastimarse o a lesionarse, se preparaban ejercicios acrobáticos en piso en segundo año y ejercicios en aparatos gimnásticos en tercer año.

Concluyendo con un entrenamiento mucho más completo que el que se llevaba en décadas anteriores.

Es notable en las entrevistas realizadas a las personas de las distintas generaciones del CUT, como la comprensión de la materia y la relación con la clase de actuación es más fuerte en generaciones de las últimas tres décadas que de los inicios de la materia en los años setenta y ochenta.

Esto fue debido a que la incursión de personas que no solo eran ejecutantes acróbatas, ya que podían hacer las analogías necesarias que aplicaban en su trabajo escénico y ante la cámara, porque quienes formaban el cuerpo docente titular de la clase, fueron los mismo desde finales de los años noventa hasta mi incursión como maestro adjunto; Dagoberto Gama, Mayra Serbulo y Gustavo Sánchez Parra, todos actores y actrices de teatro, cine y televisión.

Los catedráticos acompañaban a sus pupilos desde el primero hasta el tercer año de la carrera, junto con el maestro Raul Kaluriz que se mantuvo como maestro desde el inicio de la materia de acrobacia en 1974, hasta su retiro de la clase en el año 2018 a los 77 años de edad. 
Estos son los contenidos actuales de asignaturas:

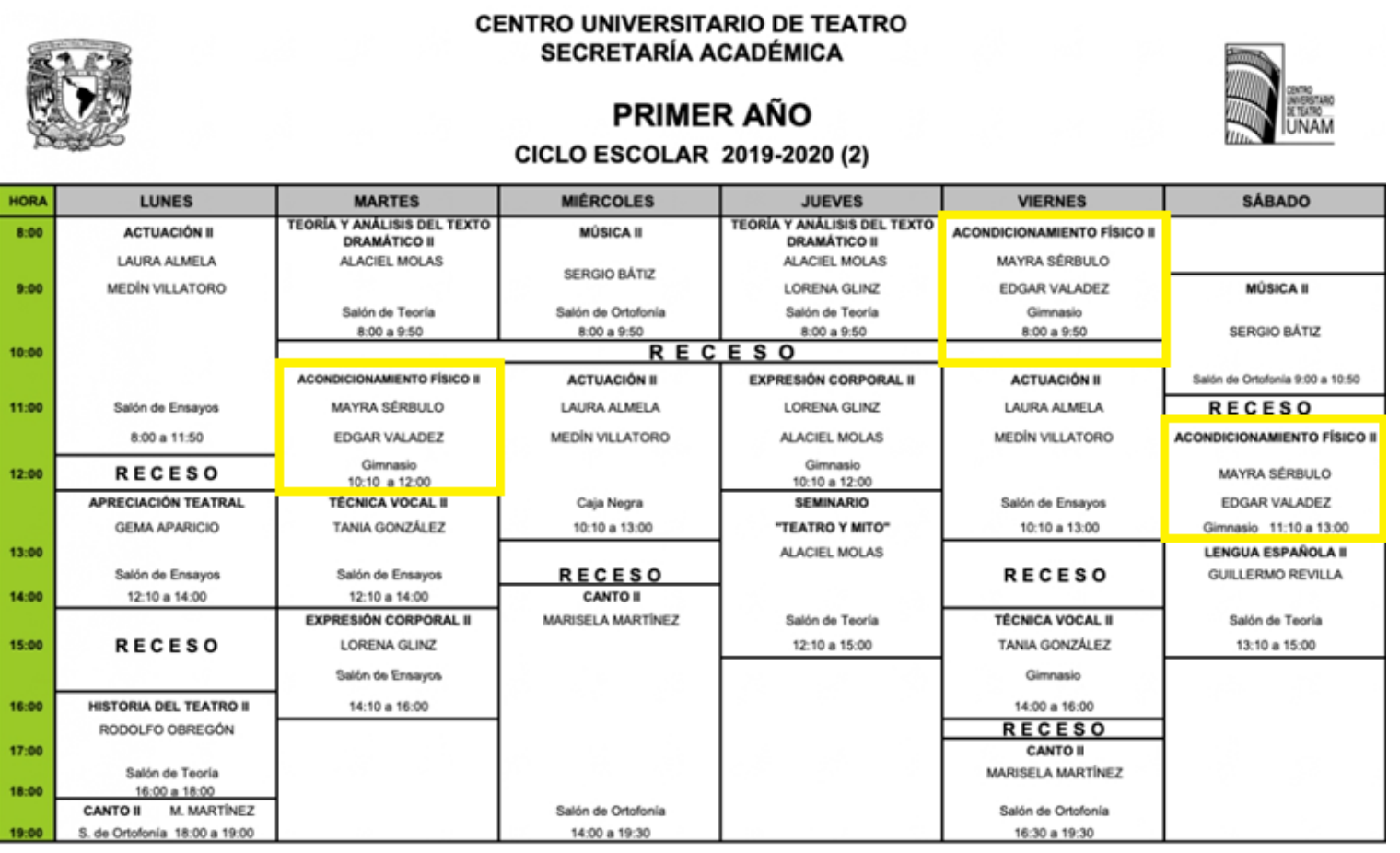

\begin{tabular}{|c|c|c|c|c|c|c|}
\hline \multicolumn{2}{|c|}{ 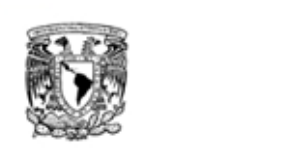 } & \multicolumn{3}{|c|}{$\begin{array}{l}\text { CENTRO UNIVERSITARIO DE TEATRO } \\
\text { SECRETARIA ACADÉMICA } \\
\text { SEGUNDO AÑO } \\
\text { CICLO ESCOLAR 2019-2020 (2) }\end{array}$} & \multirow[b]{2}{*}{ VIERNES } & \multirow{2}{*}{ SABADO } \\
\hline HORA & LUNES & MARTES & MIÉRCOLES & JUEVES & & \\
\hline \multirow[t]{3}{*}{$\begin{array}{l}9.00 \\
9.00\end{array}$} & \multirow{3}{*}{$\begin{array}{l}\text { ACROBACIAII } \\
\text { EDGAR VALAOEZ } \\
\text { OSCAR SERRANO } \\
\text { Gimnasio } \\
8.00 \mathrm{a} 9.50 \\
\end{array}$} & $\begin{array}{l}\text { MÚSSICAIN } \\
\text { SERGIO BATIZ }\end{array}$ & \multirow{2}{*}{$\begin{array}{l}\text { ACROBACIA } \\
\text { EDGAR VALAOEZ } \\
\text { OSCAR SERPANO } \\
\text { Gimnasio } \\
\text { B:00 a } 9.50 \\
\end{array}$} & $\begin{array}{l}\text { MÓSICAIV } \\
\text { SERGIO BATIZ }\end{array}$ & \multirow{2}{*}{$\begin{array}{c}\text { DANZA URBANA } \\
\text { DANIELA DE LOS PIOS } \\
\text { Sadon do Ensayos } \\
\text { 8:00a } 9: 50 \\
\end{array}$} & \\
\hline & & $\begin{array}{l}\text { Salon de Ontotonia } \\
8: 00 \text { a } 9.50\end{array}$ & & 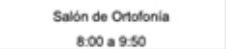 & & \multirow[t]{2}{*}{$\begin{array}{l}\text { DANZZ URBANA } \\
\text { DNNELA DE LOS RIOS }\end{array}$} \\
\hline & & REC & \multicolumn{2}{|l|}{ ES O } & \multirow{3}{*}{$\begin{array}{l}\text { TEORIA Y ANALISIS DEL } \\
\text { TEXTO DRAMATCO IV } \\
\text { ATANASIO CALENA }\end{array}$} & \\
\hline \multirow{3}{*}{$\begin{array}{l}11: 00 \\
1200\end{array}$} & \multirow[t]{2}{*}{$\begin{array}{l}\text { ACTUACION IN } \\
\text { MARIO ESPINOSA } \\
\text { PRISCIIAAIIAZ } \\
\text { DAVD HEVAA }\end{array}$} & \multirow[t]{2}{*}{$\begin{array}{l}\text { EXPRESION VERBAL } \\
\text { TANA GONZLLEZ }\end{array}$} & \multirow{3}{*}{ 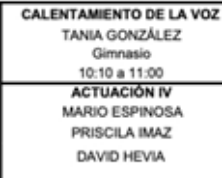 } & \multirow{3}{*}{ 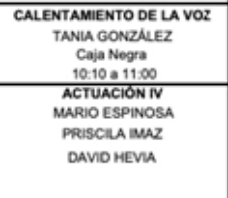 } & & $\begin{array}{l}\text { Salden do Ensayes } \\
9000 \text { a } 10.50\end{array}$ \\
\hline & & & & & & \multirow[t]{3}{*}{$\begin{array}{l}\text { TALLER DE ACTUACIÓN } \\
\text { DAVO HEVAA }\end{array}$} \\
\hline & $\begin{array}{c}\text { Cimnasis } \\
10: 10 \text { a } 1300 \\
\end{array}$ & \multirow{2}{*}{$\begin{array}{l}\text { EXPRESION CORPORAL IN } \\
\text { LORENA GUNZ } \\
\text { Cimnasio } \\
\text { 12:10 a } 1400 \\
\end{array}$} & & & \multirow{2}{*}{$\begin{array}{c}\text { EXPRESION VERBALL } \\
\text { TANIA GONZLLEZ } \\
\text { Gimnasio } \\
12: 10 \text { a } 14: 00 \\
\end{array}$} & \\
\hline \multirow[t]{2}{*}{$\begin{array}{l}13.00 \\
14000\end{array}$} & RECESO & & & $\begin{array}{l}\text { Capap Negra } \\
11: 10 \text { a 14:00 }\end{array}$ & & \\
\hline & $\begin{array}{c}\text { CANTTON } \\
\text { MaresSELA MARTINEZ }\end{array}$ & $\frac{\text { RECES O }}{\text { TEORIAY ANALISIS DEE }}$ & $\begin{array}{l}\text { Gimnatio } \\
1111091500\end{array}$ & $\begin{array}{c}\text { RECESO } \\
\text { EXPRESON CORPORALIN }\end{array}$ & \multirow{3}{*}{$\begin{array}{l}\text { MARISELA MARTTINEZ } \\
\text { Salon de OAdotonia } \\
14: 00 \text { a } 16: 30\end{array}$} & $\begin{array}{c}\text { Salbn do Enatayos } \\
\text { 11:10 a a } 15: 00\end{array}$ \\
\hline \multirow{2}{*}{$\begin{array}{l}15000 \\
16000\end{array}$} & & \multirow{2}{*}{ 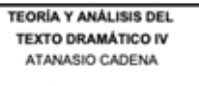 } & $\begin{array}{l}11: 10 \text { a } 15: 00 \\
\end{array}$ & \multirow{3}{*}{$\begin{array}{l}\text { EXPRESION CORPORAL N } \\
\text { LORENA GLINE } \\
\text { Gimnasio } \\
\text { 15:00 a a } 17.00\end{array}$} & & \\
\hline & & & RECESO & & & \\
\hline \multirow{2}{*}{17.00} & \multirow[b]{2}{*}{ 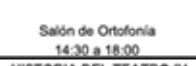 } & \multirow{2}{*}{$\begin{array}{c}\text { Salba do Tooria } \\
\text { 15:00 a } 17.00 \\
\text { CANTIO N } \\
\text { Marosela MARTINEZ }\end{array}$} & \multirow{2}{*}{ 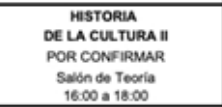 } & & & \\
\hline & & \multirow[t]{2}{*}{$\begin{array}{l}\text { CANTON } \\
\text { MAPSSELA MARTINEZ }\end{array}$} & & & & \\
\hline 10.00 & \multirow{3}{*}{$\begin{array}{l}\text { RISTORLA DEL TEATRO IV } \\
\text { RODOLFO OBREGON } \\
\text { Salion do Teoris } \\
\text { 18:10 a 20:00 }\end{array}$} & & & & & \\
\hline 19:00 & & & & & & \\
\hline 20:00 & & & & & & \\
\hline
\end{tabular}




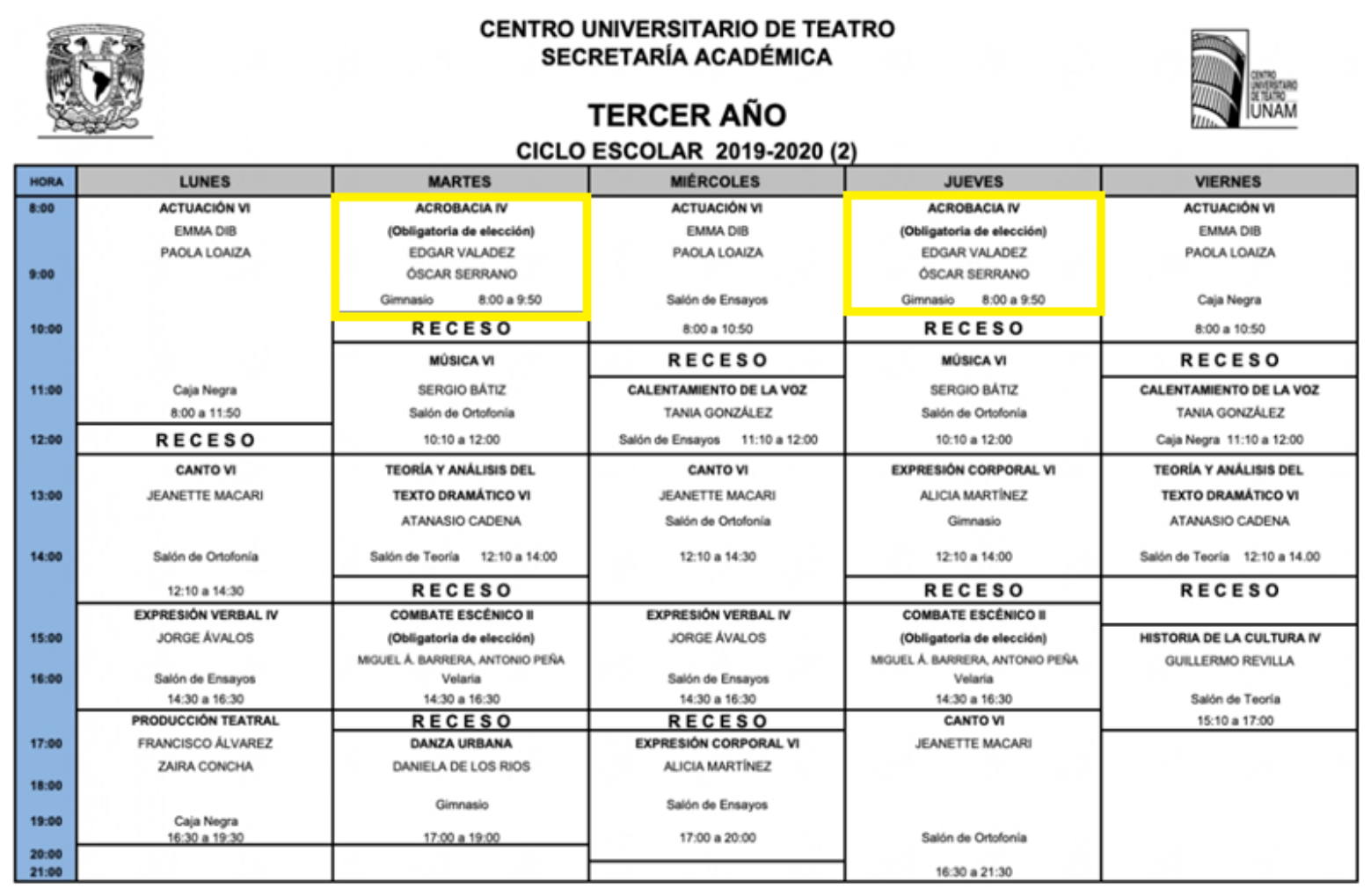

Contenido de asignaturas según el ultimo plan de estudios:

\section{ACONDICIONAMIENTO FISICO}

Esta asignatura pertenece al Campo de Cuerpo y Movimiento y se cursa durante los dos primeros semestres (Acondicionamiento Físico I: Equilibrio y ejercicios rítmicos y Acondicionamiento Físico II: Acrobacia de piso y baile coreográfico) de la Licenciatura en Teatro y Actuación.

Se relaciona directamente con las asignaturas de Actuación I: El trabajo sobre sí mismo y Técnica Vocal I: El aparato fonador. Conciencia física de la voz, ya que éstas requieren del trabajo con el cuerpo en distintos aspectos.

El acondicionamiento físico y rítmico que aquí se desarrolla permite que el alumno comprenda, seleccione y estructure los ejercicios que su cuerpo necesita para una buena disposición al trabajo escénico. 
En este primer semestre se desarrollan ejercicios físicos empleando distintas técnicas de entrenamiento para que el alumno logre acondicionar su cuerpo de una forma creativa, estructurada y precisa.

El entrenamiento físico es parte fundamental de la formación profesional del egresado de la Licenciatura en Teatro y Actuación, es una herramienta que le permite estructurar, organizar y llevar a cabo una conexión creativa integral (intelecto, emoción, cuerpo y voz) para el trabajo escénico.

En esta asignatura se le da prioridad a ejercicios que ayudan a lograr un óptimo tono muscular para el trabajo físico, psíquico y emocional que se lleva a cabo durante la licenciatura.

El alumno debe ser capaz de: a) Reconocer sus habilidades físicas de ingreso y fomentar mediante el esfuerzo la superación de las mismas para el acondicionamiento físico general; b) Identificar las partes de su cuerpo que debe coordinar para la ejecución de los ejercicios por aprender; c) Desarrollar un procedimiento para su entrenamiento físico-personal ubicando su cuerpo en el espacio, tiempo y ritmo adecuados como su principal herramienta para el inicio del trabajo escénico. És el inicio del desequilibrio corporal para encontrar el balance.

\section{ACROBACIA I y II}

Desarrollo de acrobacia de piso. Pertenece al Campo de Cuerpo y Movimiento y se cursa durante el tercer semestre de la Licenciatura en Teatro y Actuación.

Es de naturaleza práctica y constituye, por un lado, la continuidad del entrenamiento físico y la asimilación corporal de los conceptos aprendidos en Acondicionamiento Físico II: Acrobacia de piso y baile coreográfico y, por otro lado, sienta las bases para la ejecución de ejercicios acrobáticos de mayor complejidad comprendidos en Acrobacia II: Principios de acrobacia semi-aérea, Acrobacia III: Desarrollo de acrobacia semi-aérea 2 y Acrobacia IV: Integración de acrobacia de piso, semi-aérea y aérea. 
Aquí se maneja el riesgo en todo momento tanto física como emocionalmente como parte de la preparación del alumno. La acrobacia juega un papel importante en la contribución al logro del perfil de egreso del alumno, debido a que las habilidades que se adquieren le permiten integrarse en procesos creativos cuyo enfoque sea mayormente físico y lúdico.

El sentido de riesgo que implican los ejercicios acrobáticos posibilita el desarrollo de una actitud de arrojo y resolución inmediata ante el conflicto que ofrece el obstáculo y la falta de equilibrio.

Así mismo el riesgo propicia el trabajo de grupo, en tanto que, para la realización adecuada de los ejercicios de acuerdo con medidas de seguridad, se requiere de la participación consciente y conjunta del grupo.

Los ejercicios acrobáticos influyen directamente en el desarrollo de la presencia escénica de quien los realiza, al detonar en él una conciencia corporal extra cotidiana en la que el tono muscular, la resistencia física y el nivel de energía generan un estado físico y mental que se requiere en escena.

El alumno debe ser capaz de: a) Aplicar la fuerza, relajación, impulso y control que necesita su cuerpo para poder ejecutar los distintos ejercicios corporales; b) Relacionar ejercicios corporales con ejercicios mentales; c) Controlar su cuerpo para ejercer sobre él un dominio total con base en lo que cada ejercicio requiera; d) Integrar los elementos externos como otros cuerpos y trampolín para usarlos en beneficio de la ejecución.

El cuerpo que inicia el despegue, el alumno como 'ave saliendo del nido'.

ACROBACIA III y IV

Desarrollo de acrobacia semi-aérea, ofreciendo al alumno una serie de herramientas que consolidarán su nivel de control y manejo del cuerpo para la generación de impulsos a nivel piso y aéreo, usando factores externos que potencializan en fuerzas y contra impulsos como son los aparatos gimnásticos. 
Permitirá al alumno aplicar la habilidad corporal adquirida para lograr mejores ejecuciones y desempeños, así como personalizar su calentamiento y preparación para poder tener un cuerpo dispuesto y con una relajación activa.

También se pretende que cada estudiante vaya persiguiendo objetivos más elevados, conforme se va avanzando en la asignatura, porque, en efecto, en el transcurso del semestre se incrementa la dificultad de los ejercicios a los que se somete. Los diferentes grados de dificultad se encuentran vinculados con el nivel de fuerza, control y línea en las ejecuciones de piso y aéreas.

El alumno debe ser capaz de: a) Conocer las nociones de la fuerza, tensión y relajación muscular para la preparación, generación y explosión de impulsos; b) Utilizar controlada y correctamente los elementos externos para beneficio de la ejecución de ejercicios; c) Identificar y controlar el impulso de sus emociones, sus temores y resistencias, fijándose siempre un objetivo a vencer en cada sesión; d) Relacionar la contención de la energía en un ejercicio acrobático aéreo con la contención emocional que requiere un ejercicio de actuación. 
Todo es espacio, nada soy yo, cuerpo que flota, luz, oleaje; todo es del viento y el viento es aire siempre de viaje...

Octavio Paz 


\section{CAPITULO 2}

\section{Buscando la expresividad en el vuelo, en el viento.}

\subsection{Una breve consideración sobre el entrenamiento.}

Según el sitio web español www.efdeportes.es especializado en el entrenamiento deportivo, el concepto de entrenamiento es así descrito:

- Preparación para perfeccionar el desarrollo de una actividad, especialmente para la práctica de un deporte;

- Procedimiento pensado para obtener conocimientos, habilidades y capacidades.

El entrenamiento de tipo físico, es casi mecánico, ya que consiste en llevar a cabo una serie de ejercicios previamente establecidos para desarrollar ciertas habilidades o aumentar la musculatura. El objetivo de esto es lograr el máximo potencial en un periodo específico de tiempo.

El entrenamiento físico en el ámbito militar, significa conseguir las condiciones físicas para intervenir o subsistir en el combate.

El entrenamiento en materia profesional, por otra parte, es el aprendizaje que se desarrolla en el lugar de trabajo para mejorar el rendimiento de las personas.

¿Qué se aprende más allá de la técnica?

Según Barba, el aprendiz se descubre en ella, aprende a conocer mejor su cuerpo y sus bloqueos, explora las leyes del movimiento (equilibrio, tensión, ritmo) e intenta siempre extender sus límites. "El teatro y el trabajo del actor son para nosotros una especie de vehículo que permite realizarnos" ${ }^{6}$ citando Barba a Grotowski.

\footnotetext{
${ }^{6}$ BARBA Eugenio. El arte secreto del actor. Escenología A.C. México DF. 1990.
} 
Este aprendizaje pasa por un conocimiento del propio cuerpo y sus límites, por supuesto, con el fin de extenderlos, pero también pasa - sobre todo - por un trabajo sobre sí mismo.

En otra perspectiva Eugenio Barba menciona ${ }^{7}$, algunas funciones del entrenamiento para los actores y actrices.

- Interpretación de un texto dramático

La cual habla sobre la flexibilidad que tiene que tener un actor para poder interpretar variedad de textos dramáticos, personajes

- Lo que él llama la transmisión del secreto

Visión un poco más mística de la preservación del conocimiento que pasa de maestros a alumnos.

- Autoexpresión

Especializado en exteriorizar el interior.

- Formación de grupo

Vencer el individualismo.

Todo esto Barba lo resalta de modo que hace ver que un punto de quiebre en el entrenamiento de actores y actrices fue la época en la que Grotowski empieza a explorar el entrenamiento de manera muy diferente de cómo se hacía en décadas anteriores, e incluso en la tradición oriental del entrenamiento, qué consistía en aprender por imitación de su maestro hasta dominar completamente el papel a desempeñar.

${ }^{7}$ BARBA Eugenio. El arte secreto del actor. Escenología A.C. México DF. 1990. 
Se propone que el training parta, tanto de la preparación física para el oficio, como una especie de crecimiento personal por encima del nivel profesional, es el medio para controlar el propio cuerpo, dirigirlo con seguridad y a la vez es la conquista de una inteligencia físico-emocional.

El problema del entrenamiento en esos años, y yo creo que ese problema permanece hasta la fecha, es que muchos piensan que son los ejercicios quienes permiten avanzar, mientras que los ejercicios son sólo la parte aparente o visible de numerosos aspectos de un proceso de unidad.

Como afirma Barba: "Es la temperatura del proceso y no tanto el ejercicio en sí lo decisivo" (BARBA, 1990) ${ }^{8}$

\subsection{El poder de navegar en el aire.}

Cuando se asiste a un espectáculo de la ópera de Pekín o del kabuki a menudo sorprende la destreza física de los ejecutantes. Al igual que la escuela rusa de principios de siglo dónde se puede haber un virtuosismo en el entrenamiento acrobático.

Los maestros de los años sesenta y setenta rescatan ese tipo de entrenamiento que desde aquel tiempo ya planteaba una alerta, de la cual se tenía que poner especial atención.

Barba cita un aspecto esencial de la técnica acrobática:

No se trata tan sólo de aprender saltos mortales sino de afrontar a un enemigo talvez superior. [...] El entrenamiento acrobático permite al actor poner a prueba sus propias fuerzas: al principio se plantea el problema de superar miedos y resistencias de confrontarse con sus propios límites, luego se convierte en una forma de controlar energía aparentemente incontrolable. Son esas conquistas además del ejercicio y las que dan seguridad al actor aunque pienso que no puedo hacerlo soy capaz de hacerlo y esto no puede menos que transformarse en el escenario en un cuerpo decidido"(BARBA, $1990)^{9}$

\footnotetext{
8 Ibidem.

${ }^{9}$ Ibidem.
} 
Podemos ver cómo siempre ha existido esta conciencia de no sólo buscar el virtuosismo en las ejecuciones, sino de lograr que este tipo de entrenamiento nos lleve a un lugar en el que pueda ser utilizado, no como una herramienta de ejecución, sino para poder desarrollar un buen trabajo actoral en escena.

El problema muchas veces con el que nos topamos a la hora de hablar de entrenamiento físico, sobre todo aquí en México, es que se tiene escaso nivel de investigación acerca de esta práctica. Se trabaja muchas veces con base en la tradición de los maestros de décadas anteriores, que por lo general no eran actores o directores, sino deportistas, todo esto siguió haciendo sin cuestionar o plantear si estas metodologías funcionan hoy en día para que sean instruidas a los actores y actrices en formación de las distintas escuelas.

Un cuerpo que hace ejercicios acrobáticos tendrá algo de presencia escénica indudablemente, pero creo que un cuerpo entrenado con conciencia y conocimiento de lo que se pretende hacer a través de las distintas herramientas de entrenamiento físico, tendrá un porcentaje mayor de autoconocimiento, presencia escénica, herramientas actorales y recursos para la escena.

Me pregunto ¿Porque no se había hecho alguna investigación? o ¿Porque nadie se había preguntado en tantos años si este tipo de entrenamiento seguía siendo pertinente? también ¿Sólo sé seguía haciendo por tradición? y ¿Porqué de cierta manera funcionaba aunque no se tuviera mucho conocimiento del por qué?

A la conclusión que puedo llegar es que, de cierta manera indirecta o tal vez no reflexionada por estudiantes y docentes, el entrenamiento funcionaba aunque no se supiera el cómo ni las causas, y se le adjudicaba más a una percepción en el cuerpo en escena, que en la las habilidades mentales adquiridas en clase.

Se podía ver un resultado escénico de cuerpos más fuertes, alertas, presentes y energéticos de quienes llevaban a cabo esta clase de entrenamiento en esta escuela en particular, a comparación de actores que nunca habían pasado por este tipo de preparación. 
Ahora lo que planteo es, las posibilidades y ventajas tiene este tipo de entrenamiento físico, saber sí podemos lograr que todo esto que antes era inconsciente o que simplemente nadie se preguntaba (Sólo se asumía que era algo que se tenía que hacer) se vuelva algo consiente.

Si los objetivos han cambiado entonces me pregunto:

¿Qué es lo que se busca para los estudiantes al llevar a cabo esta clase de entrenamiento en el $2020 ?$

Principalmente ya no buscar el virtuosismo en la ejecución, ni lograr hacer ejecuciones acrobáticas para la escena, ya no en esta nueva visión.

Ahora se pretende plantear un entrenamiento físico con ejercicios acrobáticos para poder rescatar las metáforas y analogías que los ayuden al momento de la interpretación.

Buscar conocimiento de nuestro instrumento de trabajo, sus límites y sus posibilidades, así como entender y aplicar conceptos básicos como generación de energía, concentración, detonación, impulso, enfoque, entre muchos otros que siempre usaremos y tendremos presentes al ser artistas profesionales.

\subsection{Jugar - Volar - Domesticar - Actuar}

No conocemos más que las cosas que domesticamos ${ }^{10}$ Alexandre del Perugia

\footnotetext{
${ }^{10}$ MULLER, Carol. El training del actor, Universidad Nacional Autónoma de México, México DF. 2007
} 
El autor de la cita, Alexandre Del Perugia ${ }^{11}$, es actor, director y pedagogo, cofundador del Théâtre École du Passage en París, formador, asesor artístico e investigador en el National Circus Arts Center.

Retomando la frase "No conocemos más que las cosas que domesticamos"; hablemos de domesticar, que no es lo mismo que dominar. Uno de los significados de domesticar de la real academia de la lengua española es "Hacer tratable a alguien o algo que no lo es" "Modelar la aspereza de carácter" "Acostumbrar a la vista del hombre al animal fiero"

Casi siempre relacionamos domesticar con una acción con los animales, pensemos en esta ocasión en, como lo dice la real academia de la lengua española, hacer tratable algo que no lo es, en general la acrobacia o las ejecuciones acrobáticas son poco tratables para los humanos, son anti natura, ya que se desafía la fuerza de gravedad, y se requiere de cierto entrenamiento muscular, flexible y el manejo de una técnica específica para llegar a un resultado.

Para caminar, saltar y volar, es importante captar el espacio, conocerlo y reconocerlo mediante los sentidos la vista en primer lugar. Ayuin en hebreo y en árabe significa ojo y origen al mismo tiempo. En acrobacia el ojo es el motor del movimiento. Del vuelo al aterrizaje, el acróbata sigue un riel imaginario que traza en el espacio con la mirada y que lo arrastra. Su trayectoria es redonda." (MULLER 2007) ${ }^{12}$

¿Cuál es la diferencia entre domesticar y dominar?

Creo que el dominar, como lo dice la real academia, habla más sobre imponerse, someter, esclavizar, etc. Domesticar es sobre acostumbrarse, preparar, educar, amansar, etc. Hablemos del miedo innato que provoca la acrobacia; que para algunos es un freno y para otros un impulso.

\footnotetext{
11 Alexandre era estudiante en el conservatorio nacional de circo y mimo, fundó Être-là, un centro donde investiga el arte del juego (circo, actor, cuerpo y juego infantil). Es director artístico del grupo de investigación Rhizophages. En 1985 se convirtió en el campeón francés de esgrima teatral y trabajó con Antoine Vitez en la década de 1980.
}

${ }^{12}$ MULLER, Carol. El training del actor. Universidad Nacional Autónoma de México, México DF. 2007 
No se trata de dominar el miedo a saltar, ejecutar o jugar, vendría mejor el concepto de domesticar el miedo y convivir con él, cómo impulso vital para la acción.

Ya que al dominar el miedo e imponerse sobre él, perderíamos toda esencia, empuje y vitalidad para poder realizar cualquier acción, y así se pierden elementos muy importantes como la concentración, el enfoque, el presente, la visualización de la acción y el placer por realizarla, todos fundamentales en el hecho escénico.

La concentración preludia a la acción. No es un repliegue sobre sí, una contracción centrípeta (hacia adentro) o cerrada, al contrario, se emparenta con una forma de disponibilidad y de escucha, que produce el movimiento justo" (MULLER 2007) $)^{13}$

Así, al hablar de domesticar el miedo podemos entender que lo que pretendemos no es deshacernos de él, si no avanzar con él, que sea nuestro aliado, nuestro combustible para poder alentarles a dar ese salto mortal o dar ese paso para entrar a escena, con la misma concentración, escucha, cuidado y vitalidad en ambas acciones.

Según Del Perugia, domesticar significa "crear lazos, ligar el exterior y el interior, ligar aire y hombre" con esto puedo relacionar que tanto el entrenamiento acrobático, como el entrenamiento actoral, debe de enlazar esta forma de concentrar el exterior con el interior para el desarrollo de las acciones corporales.

El acróbata y el actor deben buscar una dinámica centrífuga (hacia afuera). Es ella la que da al movimiento su presión y su belleza. Es ella la que hace a la inmovilidad plena, densa e intensa vivida en esta extensión y esta plenitud la inmovilidad se convierte en una especie de triunfo del movimiento" (MULLER 2007) ${ }^{14}$

La cita de Del Perugia, me hace recordar las clases con mis estudiantes en el CUT y una parte del libro ZEN en El arte del tiro con arco.

\footnotetext{
${ }^{13}$ MULLER, Carol. El training del actor. Universidad Nacional Autónoma de México, México DF. 2007

${ }^{14}$ Ibidem.
} 
¿Cuál es el momento más poderoso de un salto acrobático en las aulas? ¿Es el momento en el que se está en el aire?

Talvez si fuéramos una escuela para deportistas o gimnastas, sí, pero el momento donde podemos ver la síntesis del salto, la concentración, la energía potencial a punto de convertirse en energía cinética y mecánica es el momento antes que se ejecute el ejercicio.

Podemos ver a través de los ojos del estudiante, la tensión de sus músculos y en su respiración elementos intangibles que se hacen tangibles como: la concentración, el enfoque, el análisis, la energía, la fuerza, la memoria, entre otros. Se vuelven cuerpo, se vuelven vida.

Muchas veces ya no importa la ejecución del ejercicio, porque si se llega a ese momento, se ha avanzado y se ha entendido lo que se busca, es precisamente el estado en el que se tendría que estar al momento de participar en un hecho escénico.

El arquero se detiene para ser consciente de él mismo, como quien está comprometido en golpear el centro de la diana a la que se enfrenta. Este estado de inconsciencia se realiza solo cuando, completamente vacío y librado a sí mismo, se convierte en el único que tiene la perfecta habilidad técnica, y aun así hay una suerte de orden diferente que no se puede lograr por ningún estudio progresivo del arte. (HERRIGEL, 1999) ${ }^{15}$

También relata este estudio que cuando un maestro del tiro con arco zen tiene toda la concentración y energía para hacer el tiro perfecto, este no tira la flecha.

En algunas ocasiones antes de realizar una ejecución acrobática, observo si un alumno o alumna está en este estado tan puro, si es así detenemos todo, no importa la ejecución, sabemos que la va a realizar, mejor analizamos su sentir y su forma de estar en el presente, como esta su cuerpo, como esta su mente, su respiración, su concentración, etc. Muchas de las respuestas son: "Estoy lista. Estoy

\footnotetext{
${ }^{15}$ HERRIGEL, Eugen, El zen del arte del tiro con arco, Editorial Kier, México DF. 1999
} 
preparado. Sé lo que tengo que hacer y lo voy a hacer. Podría hacer cualquier cosa en este momento. Estoy en el estado ideal."

Y en ese momento hacemos las analogías con la clase de actuación. Por ejemplo, al estar en clase con alumnos y alumnas del segundo año que realizan tareas en la clase de actuación con textos de Shakespeare, pedimos tener siempre a la mano un párrafo pequeño de texto, que les guste mucho o que les cause problemas, la consigna es tener siempre ese texto listo y de memoria.

Cuando hemos avanzado con las clases, llega el momento de ejecutar saltos aéreos auxiliados por el mini tramp, que es un aparato para maximizar los impulsos por rebote, el cual requiere mucha fuerza y concentración para su uso.

Como se menciona en párrafos anteriores, cuando detecto que un alumno o alumna está en un estado de concentración, disposición de cuerpo y mente, de la nada le grito "texto", y dice su texto con esa energía previa al salto, lo cual resulta para todos en el grupo y para el estudiante en cuestión un gran descubrimiento.

Lo mismo para cuando después de un salto de alta dificultad, después del aterrizaje grito "texto", y la fuerza, contundencia y vivacidad con que se dice el dialogo es asombrosa para todos, después de eso se hacer un análisis de lo ocurrido y la reflexión análoga con la actuación.

Para mí, el vértigo está en el origen del placer de actuar, el propósito no es la ejecución, sino el placer y el descubrimiento, así como el niño descubre y experimenta el mundo por medio de sus juegos, el alumno modifica la consciencia y la visión de sí mismo y de su ambiente por medio de la actuación. (MULLER 2007) ${ }^{16}$

Creo que es importante volver a recalcar la importancia del cambio de paradigma de los últimos años en las materias de acrobacia que se imparten en el CUT.

Se rompió con una tradición de cuarenta y cuatro años, para dar paso a un enfoque nuevo. Cuando antes solo se le daba importancia a la construcción de cuerpos atléticos, ahora se le da importancia a la construcción de conciencias,

\footnotetext{
${ }^{16}$ MULLER, Carol. El training del actor, Universidad Nacional Autónoma de México, México DF. 2007
} 
sensaciones y descubrimientos corporales individualizados en beneficio del trabajo que realizaran como profesional.

El pedagogo no debe de ser un fabricante de hombrecillos a su imagen sino simplemente abrir puertas mostrar caminos dar el gusto por la exploración y la posibilidad de soñar. (MULLER 2007) ${ }^{17}$

En otras palabras buscamos la liberación y la expresión libre del cuerpo usando como pretexto ejercicios acrobáticos, pensados en las particularidades y posibilidades de cada cuerpo.

Invitando, no obligándoles a descubrir sus sensaciones al realizar este tipo de entrenamiento y que son capaces de lograr al domesticarlo.

En el aire quiero que DOMESTIQUE su miedo y comience a soñar.

Reinventar el movimiento en su precisión y singularidad. (MULLER 2007) ${ }^{18}$

\footnotetext{
${ }^{17} \mathrm{lbidem}$.

${ }^{18}$ Ibidem.
} 


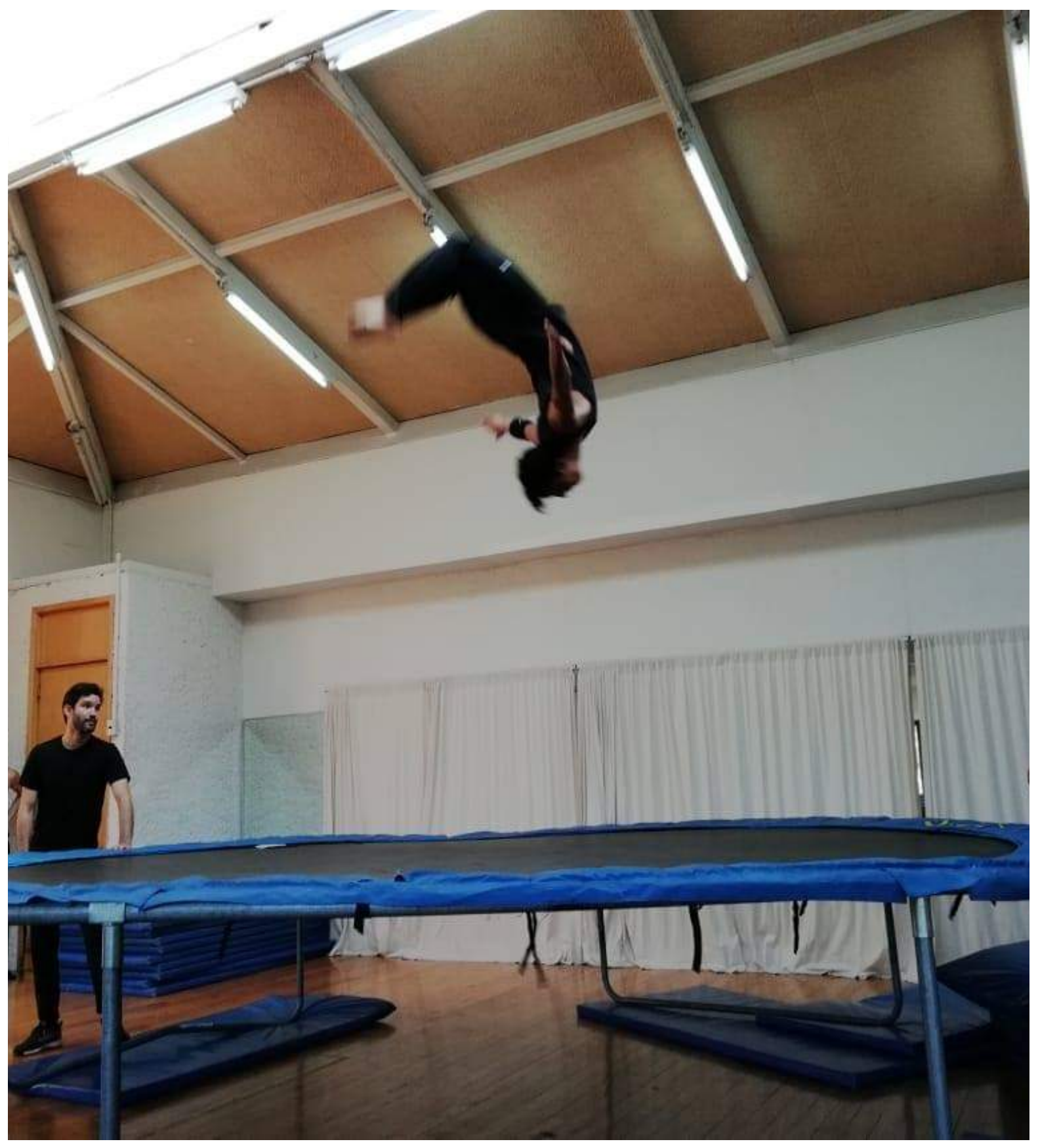

Foto 1. Salto mortal extendido hacia atrás.

AP (Archivo Personal) 
Pies... para qué los quiero, si tengo alas para volar.

FRIDA KHALO 


\section{CAPITULO 3}

\section{Los estudiantes jugando a ser pájaros}

\subsection{El entrenamiento acrobático para el actor o actriz en formación}

El Plan de estudios actual de la licenciatura en teatro y actuación de la CUT contiene en el 1er. año, la disciplina Acondicionamiento físico I: Equilibrio y ejercicios rítmicos. Con una carga de trabajo de 4 horas por semana y 64 horas en el semestre, el estudiante aprende a:

- Crear una rutina de calentamiento.

- Ejercitar su aparato cardiovascular.

- Generar fuerza y resistencia a la fuerza en sus músculos.

- Practicar ejercicios de equilibrio individual, de parejas y en equipo.

- Aprender los principios de la acrobacia en piso.

- Fortalecer el sentido del ritmo, individualmente, parejas y equipos.

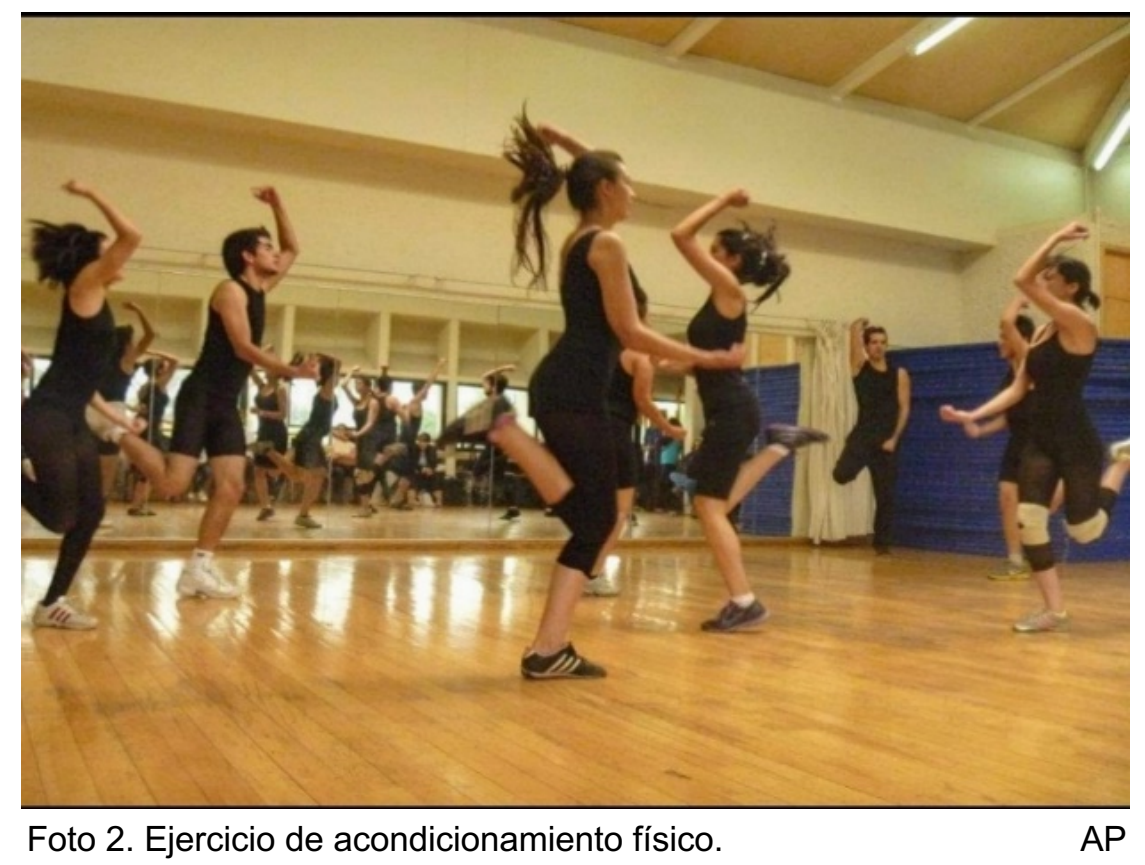




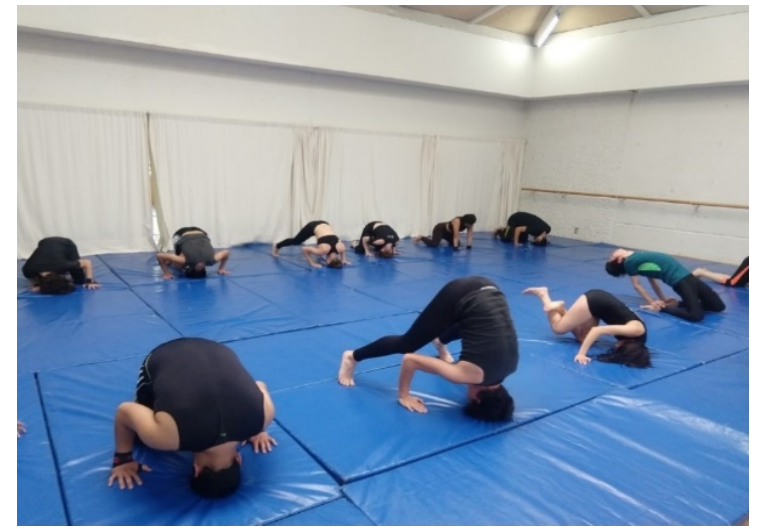

Foto 3. Calentamiento articular.

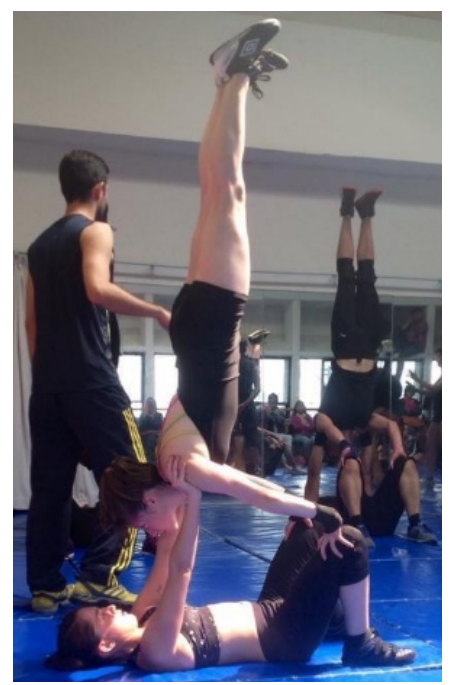

Foto 5. Ejercicio de equilibrio.

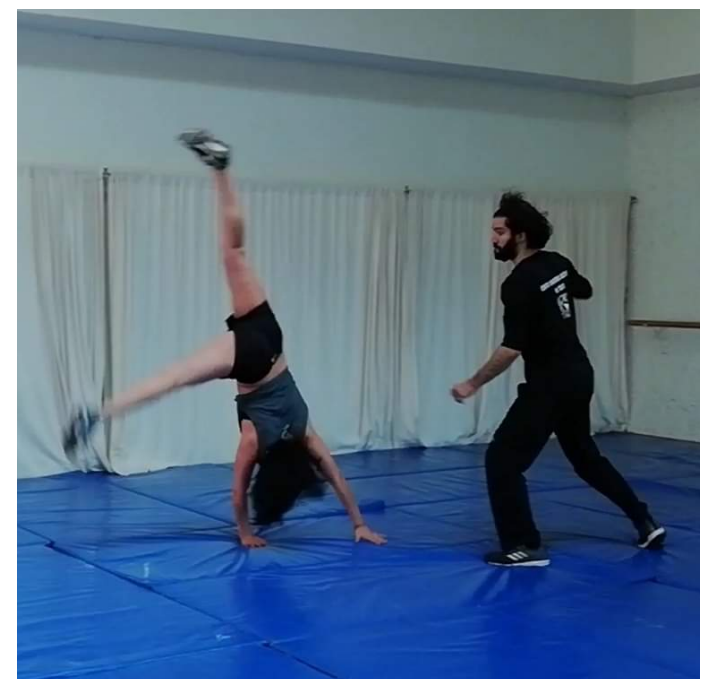

Foto 7 y 8 . Redondilla enlace flip flap.

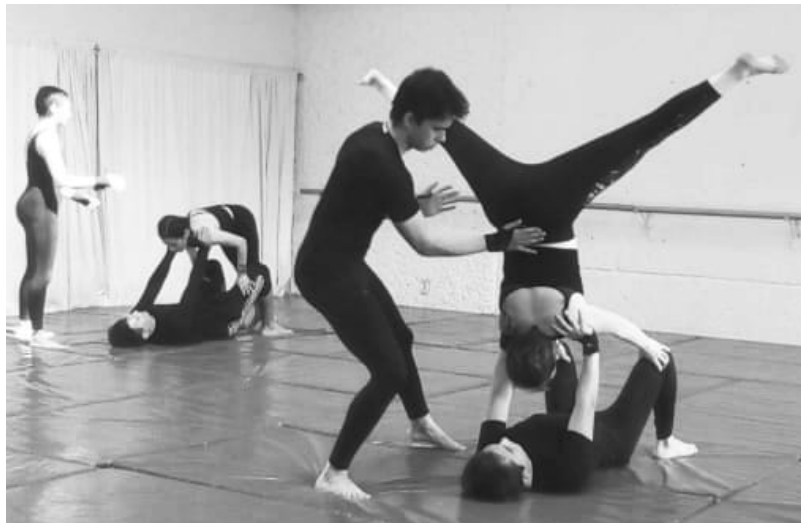

Foto 4. Ejercicios de equilibrio en parejas.

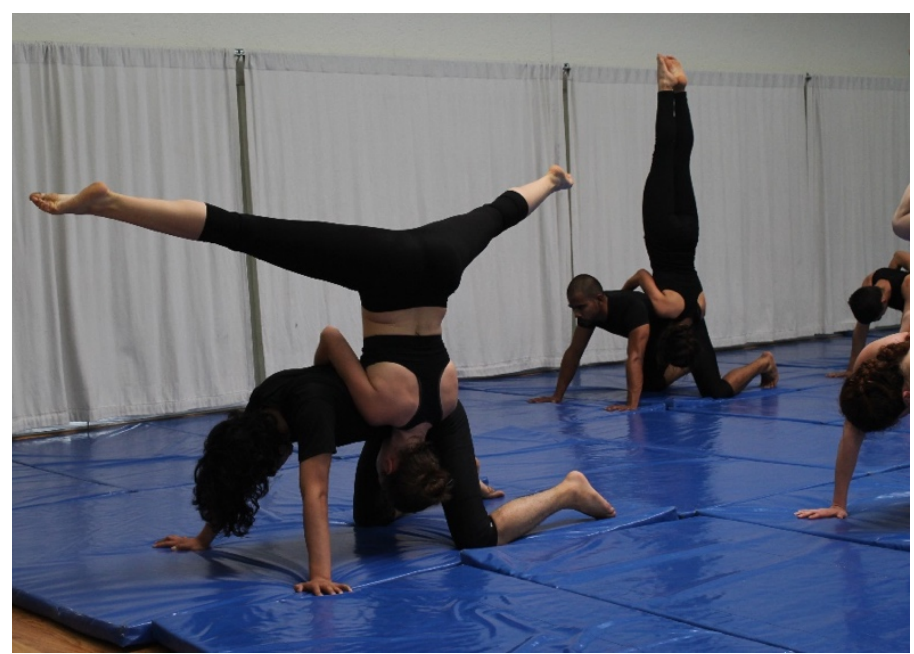

Foto 6. Ejercicio de equilibrio.

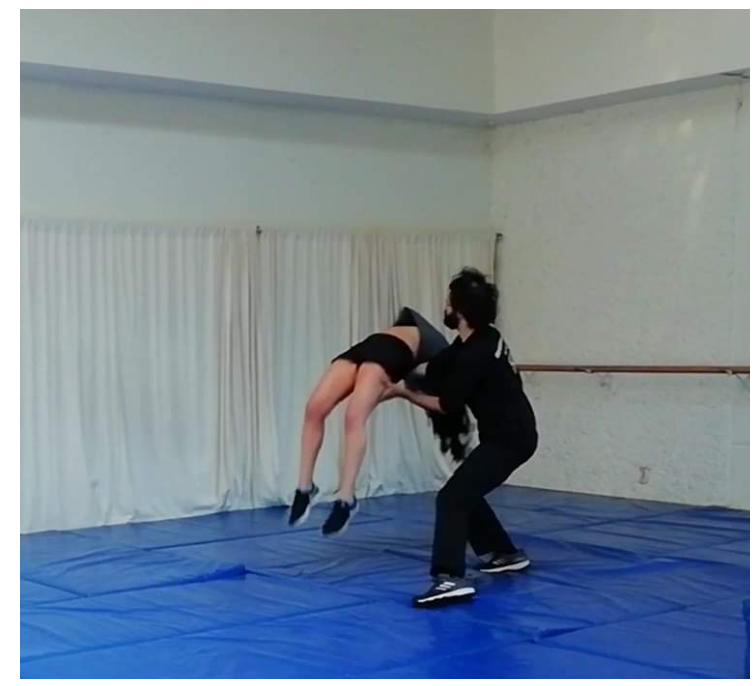

Foto 8.

AP 
En el 2do. Año, la disciplina Acrobacia I: desarrollo de acrobacias de piso, con una carga de trabajo de 4 horas por semana y 64 horas en el semestre total, el estudiante aprende a:

- Continuidad del acondicionamiento físico.

- Complementar con acrobacia en piso.

- Tipos de caídas y aterrizajes.

- Iniciar el aprendizaje de la acrobacia semi-aérea con aparatos.

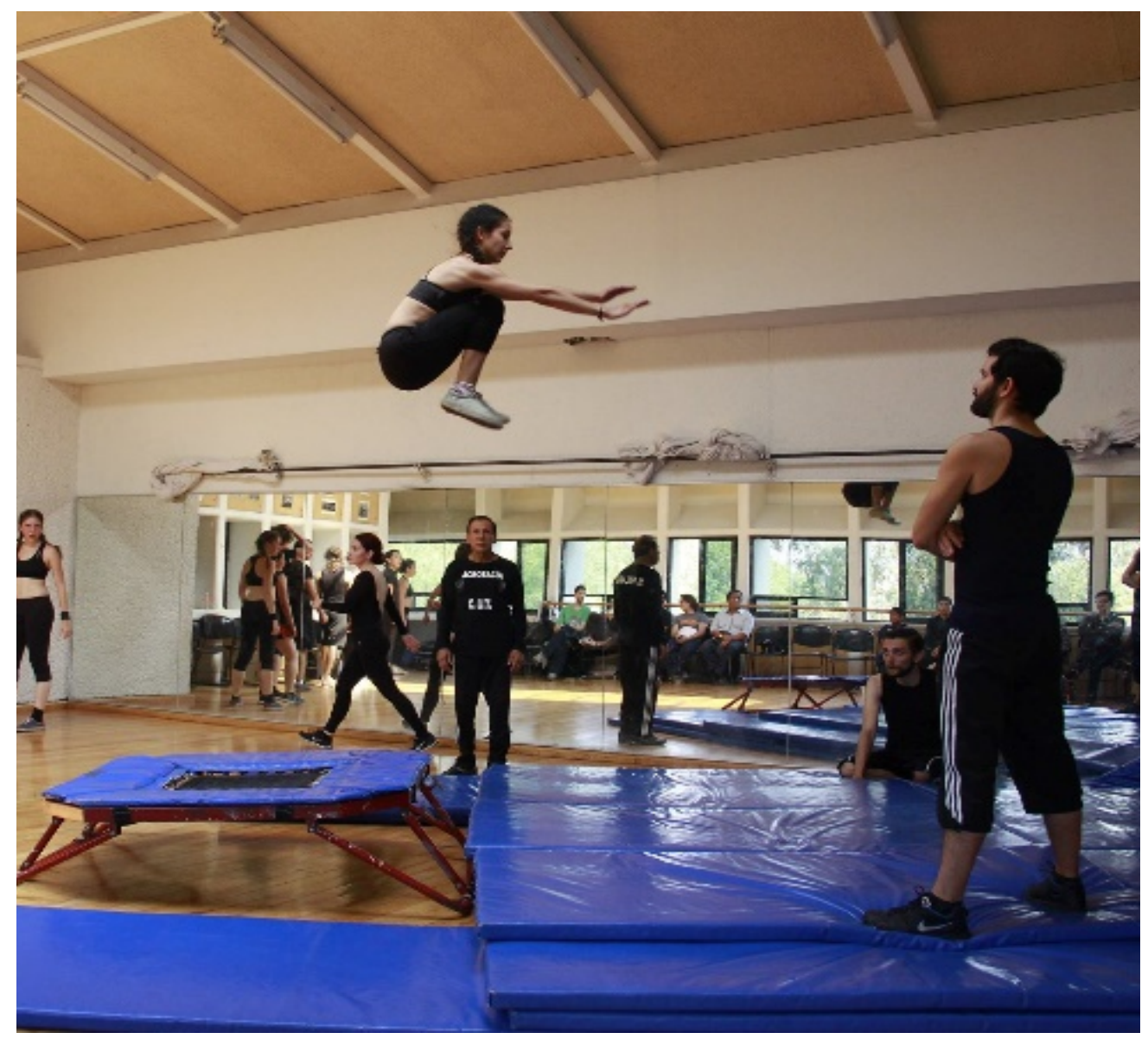

Foto 9. Salto en mini tramp rodillas a pecho. 
Foto $10 .{ }^{19}$
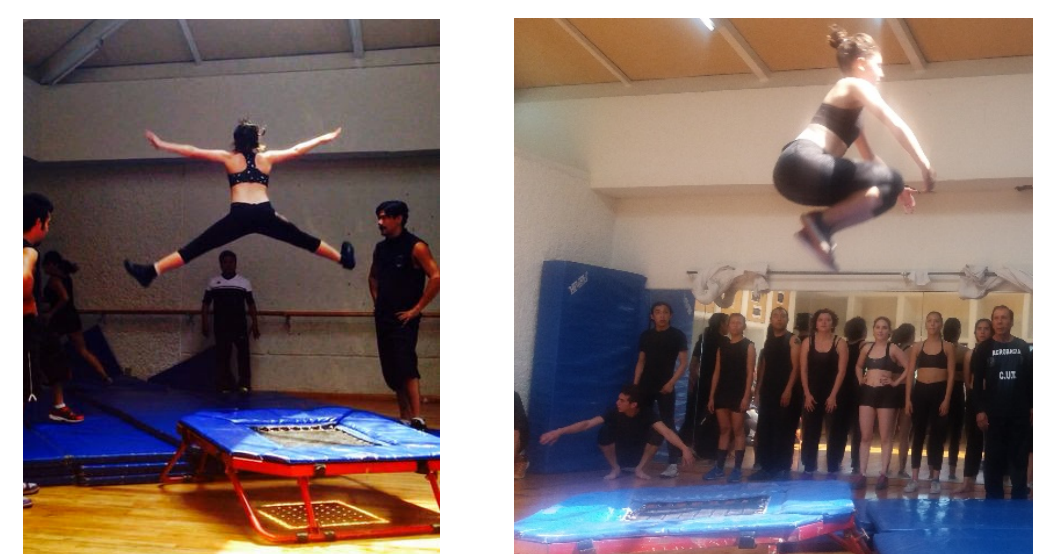

Foto 11.

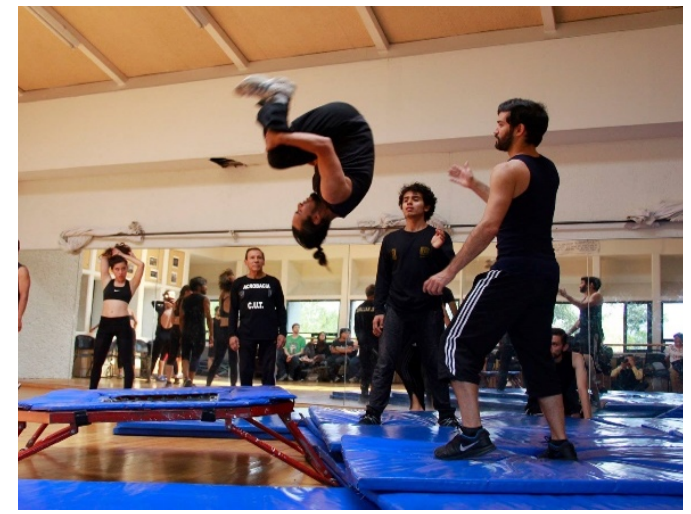

Foto 13.

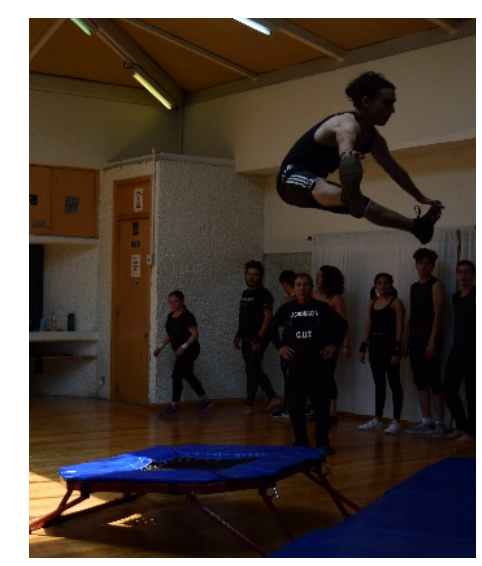

Foto 12.

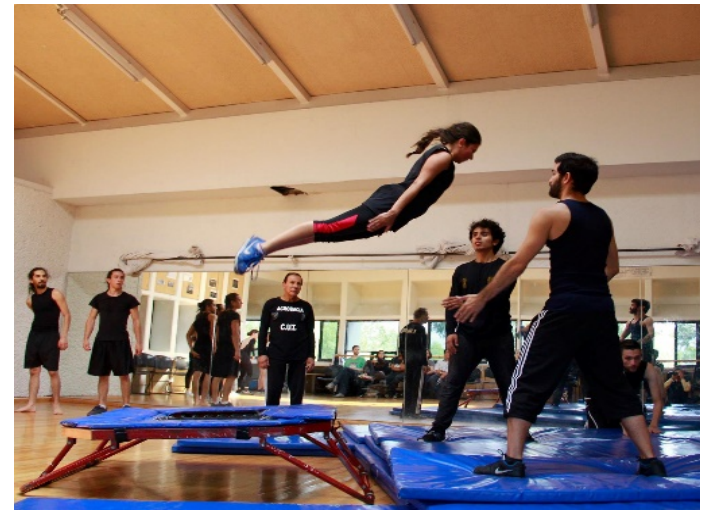

Foto 14.

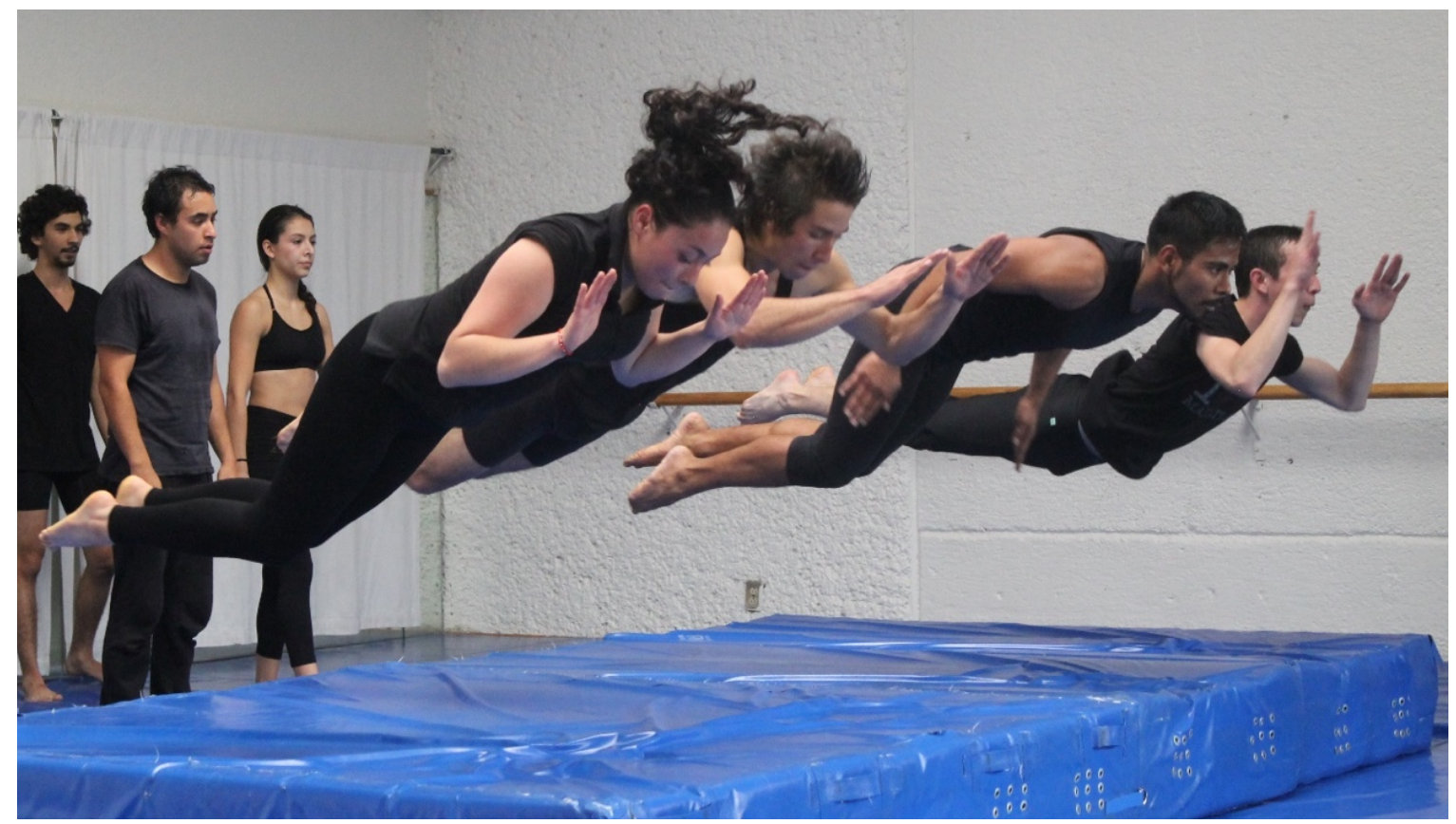

Foto 15. Ejercicio de caida sobre colchones.

${ }^{19}$ Foto 10 a 15 . Ejercicios de saltos en minitramp. 
En el 3er. año, La disciplina Acrobacia III: Desarrollo de acrobacias semiaéreas, con una carga de trabajo de 4 horas por semana y 64 horas en el semestre total, el estudiante aprende a:

- Ejercicios acrobaticos semi aereos con obstaculos

- Aterrizaje de ejercicios con obstaculos

- Ejercicios acrobaticos aereos con aparatos

- Entrada, salida y aterrizaje de ejercicios aereos

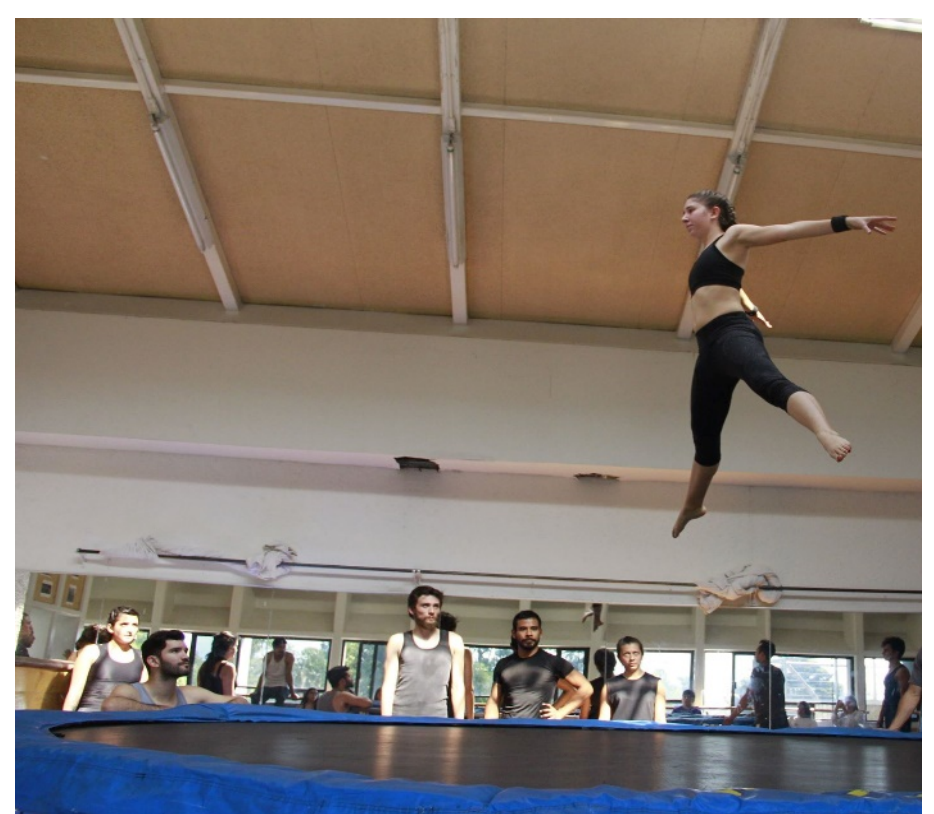

Foto 16. Ejercicio en cama elástica.

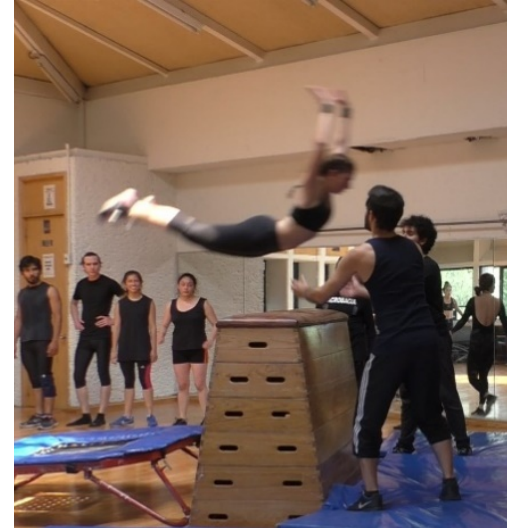

Foto $17 .{ }^{20}$

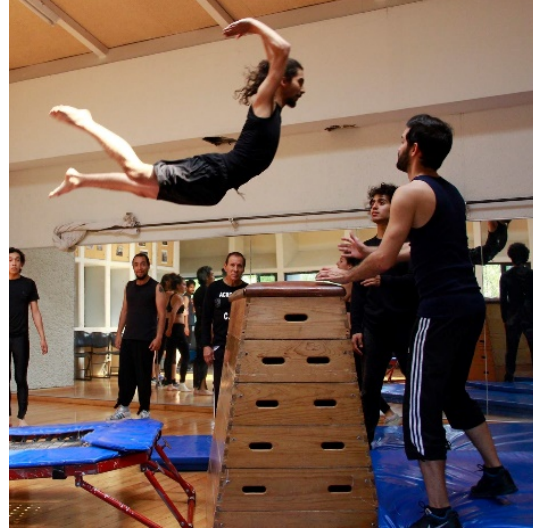

Foto 18.

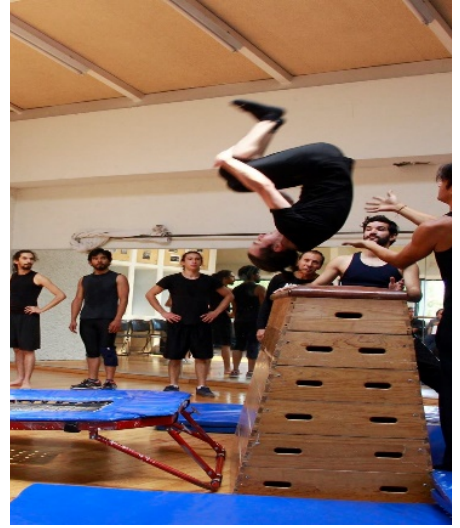

Foto 19.

\footnotetext{
${ }^{20}$ Fotos 16 a 19. Ejercicio de salto en minitramp con obstáculo de trapezoides.
} 


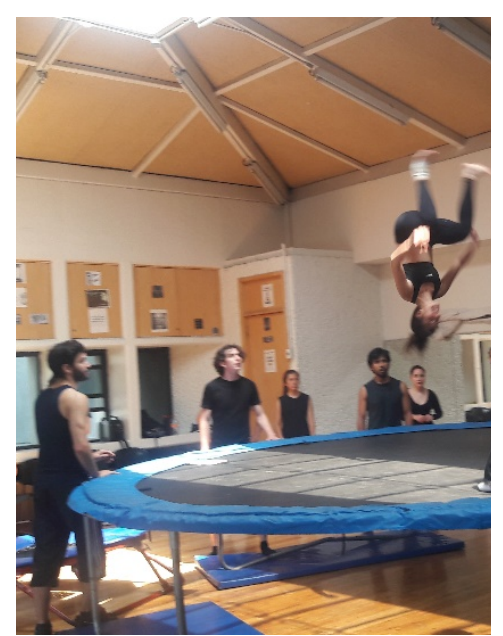

Foto $20 .^{21}$

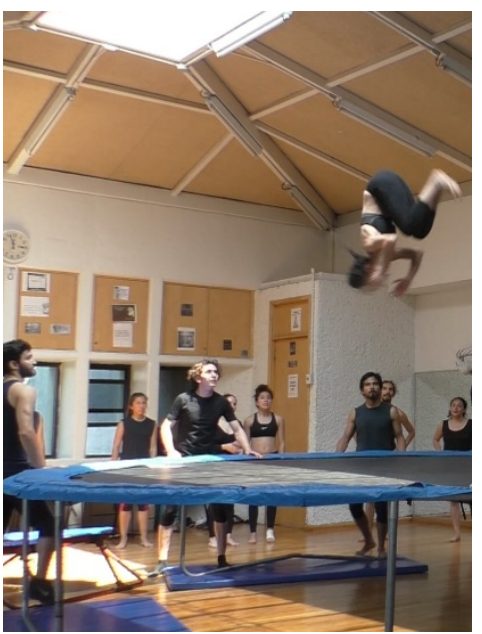

Foto 21.

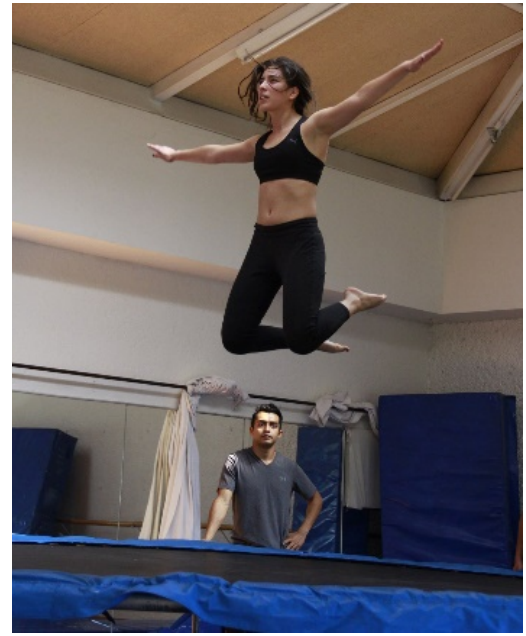

Foto 22.

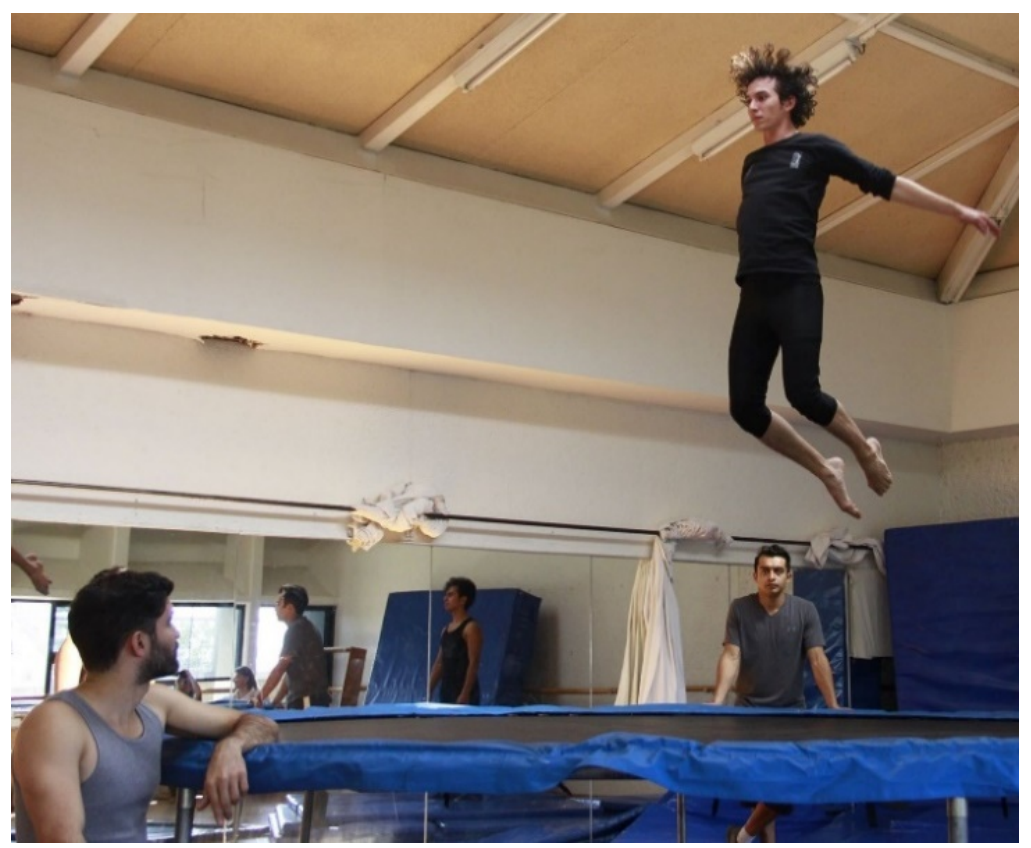

Foto 23.

${ }^{21}$ Fotos 20 a 23. Ejercicios en cama elástica. AP. 
Volviendo a una de la primera pregunta de la introducción de esta investigación: ¿Cuál es la razón o criterio de usar el entrenamiento gimnástico/acrobático como preparación corporal en el CUT?

¿Por qué no usar entrenamientos o disciplinas como yoga, taekwondo, pilates, parkour, atletismo, crossfit, danza, lucha grecorromana, etc. en una escuela de actuación?

Creo que las técnicas antes mencionadas también ayudarían mucho al desarrollo corpóreo expresivo, si es que alguien especializado en esas áreas pudiera hacer las metáforas necesarias para poder convertir un entrenamiento deportivo en una actividad o herramientas físicas para el desarrollo actoral de los estudiantes del centro.

En el caso del CUT, como ya se mencionó con anterioridad en otro capítulo, la clase de acrobacia fue instaurada y desarrollada durante muchos años por un maestro acróbata, no por un actor o director, con lo cual el entrenamiento deportivo estaba por encima de entrenamiento físico/expresivo que debía de proporcionar la materia.

A pesar de ese enfoque, más deportivo, los egresados y egresadas mencionan en algunas entrevistas que sentían que sus cuerpos eran diferentes a como habían iniciado el proceso, que gracias a superar muchos ejercicios, tal vez inconscientemente, adquirieron herramientas que los ayudaban a tener eso que muchos llaman "presencia" "energía" "vivacidad" sobre el escenario.

Entonces en respuesta a la pregunta ¿porque la acrobacia? creo que a mí en lo personal, como alumno y como actor, me ha ayudado usar las herramientas aprendidas en la clase en pro de mi trabajo como profesional, y creo que puede ser útil a muchos estudiantes para descubrir y seleccionar instrumentos útiles en su desarrollo como entes creativos e intérpretes.

También indirectamente el trabajo con el cuerpo tiene relevancia en esta clase, ya que al contener algunos ejercicios de entrenamiento deportivo, 
inevitablemente el cuerpo sufre un cambio positivo estructuralmente hablando, así como conciencia sobre los límites a los que se puede llevar.

Una de las misiones o el objetivo principal de las clases en generaciones anteriores era: homologar y construir cuerpos que pudieran ejecutar todos los ejercicios acrobáticos a la perfección, para poder ser usados en escena.

Lo cual era una misión imposible, ya que no somos un centro de deporte de alto rendimiento, somos una escuela de teatro, con cuerpos de características muy diferentes, lo cual hace al teatro y sus procesos mucho más gustoso, al poder trabajar con cuerpos diferentes entre sí.

Los cuerpos e historias corporales eran tan ricas y diversas que evidentemente no se podía llegar a la meta de homologar cuerpos entrenados, ni realizar todos los ejercicios acrobáticos, lo cual generaba rechazo hacia la clase y frustración por un gran porcentaje de estudiantes en aquellos años.

\section{Como menciona Eugenio Barba:}

En el primer periodo de nuestra existencia todo los actores hacíamos todos los ejercicios en un común ritmo colectivo, luego nos fuimos dando cuenta que el ritmo es distinto para cada individuo. Algunos poseen un ritmo vital más rápido, otros más lento. (BARBA, 1990)22

En el CUT, en los últimos dos años se ha pretendido avanzar por ese camino, el de la "individualización del entrenamiento" entre muchas razones, por ejemplo, que los cuerpos de las nuevas generaciones son más frágiles, más sedentarios y más atrofiados por lesiones o genética.

Lo cual nos lleva a profundizar, no en el trabajo corporal-deportivo, si no en el trabajo corporal-expresivo-actoral, que creemos como profesorado es el que ayuda al artista al momento de estar en escena.

\footnotetext{
${ }^{22}$ BARBA Eugenio. El arte secreto del actor. Escenología A.C. México DF. 1990
} 
Llevándolos de la mano individualmente, para que se dé cuenta de los logros obtenidos y de los obstáculos superados para llegar a hacer cierta clase de ejercicios, siempre cuidando su integridad física y mental, haciéndolos analizar y comparar este tipo de trabajo físico con el trabajo actoral.

Lo que viví, como alumno, tiene que ver con la capacidad que tenía en ese momento para poder asimilar los conocimientos y poder aplicarlos a la hora de las clases de actuación.

Ya que aunque el enfoque era más hacia aprender a ejecutar ejercicios, siempre nos hacían, pocas pero contundentes, comparaciones con momentos escénicos, por ejemplo refiriéndose a que tipos de energía teníamos que manejar, pero muchas otras veces, se ponía más atención en primero resolver el ejercicio físico que analizarlo y compararlo con elementos actorales.

Entonces en ocasiones podíamos fácilmente, varios compañeros y yo, hacer observaciones sobre los ejercicios y sentir como ese acto acrobático podía compararse con el acto escénico a la hora de hacer ejercicios en la clase de actuación.

Dado que podíamos resolver con soltura los ejercicios, no dábamos el lujo de entrar en este análisis, pero lo que pasaba con otros compañeros y compañeras, era que el miedo, la frustración y la falta de habilidad, hacían que la clase se volviera en momentos de terror y de bloqueo mental, lo cual no permitía de ninguna manera hacer algún tipo de analogía con la actuación.

Aunado al método que utilizaban algunos de los maestros, aunque ellos lo desconocían, lo llevaban a cabo, es conocido en psicología del deporte como "Refuerzo negativo". 


\subsection{El refuerzo negativo o el asesinato del aprendizaje}

El refuerzo se encarga de que la persona, en este caso el deportista, aumente el tipo de comportamientos reforzados. Será positivo cuando este refuerzo valore sus esfuerzos, resultados, y será negativo cuando los castigue.

Un deportista desmotivado a base de refuerzos negativos puede llegar incluso al abandono total de la práctica de cualquier tipo de deporte.

Un buen entrenador o psicólogo deportivo se encarga de gestionar correctamente todos estos refuerzos de tipo positivo y negativo con el fin de mejorar el rendimiento del deportista o el equipo a su cargo, ya que estos refuerzos pueden ser administrados a nivel individual o a nivel grupal. Los refuerzos negativos se suelen usar para mejorar la disciplina del deportista sobre todo de élite ya que es algo fundamental para llegar al éxito. ${ }^{23}$

No todo refuerzo negativo es malo, de hecho es una herramienta muy usada en el entrenamiento deportivo para alcanzar la excelencia, pero se tiene que saber con qué tipo de personas se usa, porque no todos los individuos reaccionan igual a los refuerzos de la misma manera para mejorar su rendimiento, ya sea positivo o negativo.

Es ahí donde entra la individualización del entrenamiento, ya que el docente tiene que ser capaz de analizar a sus discípulos para poder saber qué clase de refuerzo debe utilizar con cada uno de ellos, para que puedan comprender mejor las metáforas y analogías de la clase de acrobacia con la actuación y así puedan aprovechar más la clase.

El problema que se tenía en años anteriores en el CUT, era que se contaba con maestros que solo usaban el refuerzo negativo para dar la clase, y lo usaban con todos por igual, lo que provocaba desmotivación, angustia, estrés y rechazo.

Por ejemplo, durante las clases siempre se subrayaba en anteriores años lo que estaba mal: "Ese movimiento está mal hecho" "No te salió bien", "Así no" "Estas

\footnotetext{
${ }^{23}$ https://psicologia.laguia2000.com/conductismo/los-refuerzos-en-la-psicologia-deportiva
} 
muy pesado", "Que no entiendes", "Te vas a lesionar", "No sirves para esta clase", "Repítelo hasta que te salga", "No tenga miedo", "Pero si es muy fácil porque no puedes", "No llores, hazlo".

Para un pequeño porcentaje de personas este tipo de refuerzos pueden resultar alentador, retador y hacen que se concentren más para poder alcanzar la meta que se proponen.

Pero para la gran mayoría parecían ataques, hacían que entraran en pánico y se bloqueaban para realizar cualquier tipo de ejercicio, lo cual orillaba a los estudiantes muchas veces a lesionarse.

Esta fue una de las conductas que empecé a notar cuando inicie como maestro adjunto, además de darme cuenta de una práctica de segregación de personas que carecían de los elementos corporales y habilidades físicas para realizar las ejecuciones en clase.

Detecté un área de oportunidad, una grieta para poder entrar de lleno a la práctica docente, ayudando a los maestros a motivar a los que, por decirlo de alguna manera, estaban olvidados, ya que algunos maestros en turno solo se preocupaban por la correcta ejecución de los ejercicios.

Desde que era estudiante comencé a generar métodos o estrategias para poder abordar a mis compañeros y compañeras de clase y a ayudarlos con problemas de ejecución de ejercicios, dado que a mí se me facilitaban y podía ser capaz de hacer la conversión a mí quehacer en otras clases, me enfocaba en ser un auxiliar de la clase desde que fui alumno y años después a ser maestro adjunto, hasta llegar a ser titular de la materia.

Con el pasar de los años puedo empezar a distinguir que tipo de estudiantes entran a la clase, con sus carencias y habilidades, y así poder saber que metodología o herramienta utilizar con cada uno para poder descubrir juntos a lo que nos enfrentamos, y poder transitar por ese camino ganando las herramientas necesarias para su desarrollo artístico. 
Algunas preguntas que surgen sobre el entrenamiento acrobático, a partir de estas reflexiones son:

¿Hay modelos a seguir?

Creo que cada pedagogo crea su metodología o sigue por el camino empírico de la observación e imitación; en mi caso me base en los modelos implantados por los maestros anteriores, pero modifique de manera drástica el material, pensando en la individualización del entrenamiento, reducción de la ejecución y aumento de en análisis de la relación físico actoral.

Una vez que existe el dominio y la libertad de la ejecución del ejercicio, así como su comprensión a nivel físico y mental, existen un sin número de variantes de los ejercicios donde tiene cabida el juego y la creatividad del individuo para crear nuevas posibilidades.

Lo cual nos lleva a conectar esta reflexión con algunos procesos actorales, por ejemplo, una vez dominando el texto y hecho el análisis, nos podemos dar el lujo de jugar y explorar distintos matices de actuación y llegar a crear ese momento en escena.

Este análisis corporal al hacer ejercicios resulta ser un ejercicio altamente relacionado con la actuación, ya que en ambas disciplinas podemos darnos cuenta que primero debemos dominar ciertos aspectos fundamentales para poder empezar a desplegarlas a alas de la creación.

Al igual que la creación, la improvisación tiene lugar en el entrenamiento físico, una vez que podamos conocer las limitantes y las fuerzas de nuestro instrumento, podemos empezar a inventar o descubrir otras posibilidades que tienen los ejercicios.

Siempre de una manera segura, donde se privilegia la salud mental y física, siempre respetando el ritmo de cada individuo, para poder llegar a explorar todas las opciones sin poner en riesgo la integridad. 


\subsection{El salto mortal de alumno a maestro principiante}

\section{EDGAR VALADEZ}

Soy un actor que descubrió su vocación mientras estudiaba ingeniería industrial y de sistemas en la Universidad autónoma del noreste en la ciudad de Torreón Coahuila, México, de donde soy originario.

Al encontrarme estudiando ingeniería en el año 2002, me vi tentado a entrar a un taller de teatro en la universidad, por pura curiosidad. Me di cuenta de lo lúdico y entretenido que eran los ejercicios lo cual me atrapo y me hizo querer conocer más.

Fui invitado posteriormente a formar parte de un taller en un teatro de la región por el mismo director del taller de la universidad, ahí pude apreciar más a fondo que era la escena amateur y de que se trataba el mundo actoral.

Surgió mi interés por seguir los pasos de mis compañeros que se profesionalizaban, porque ya este taller local no nos podía ofrecer más herramientas o mayores retos. Permanecí en el taller de teatro Isauro Martínez del 2003 al 2006 y termine la carrera de ingeniería contra viento y marea.

Pocos meses después ya estaba presentando el examen de admisión a una de las escuelas más destacadas en el país, el Centro Universitario de Teatro (CUT).

Ingrese al CUT en el 2007. Para mí todo era nuevo, las clases, el tipo de teatro que veía en la ciudad, los maestros y las maestras, el esfuerzo físico y mental que requería el arte. Me fue llenando de herramientas, un gusto por cierta estética teatral, una forma de actuar y hacer teatro.

Después de mi paso por el CUT me concentre, como todo egresado, en poder tener el mayor número de proyectos para poder subsistir económicamente. No importaba si era teatro, cine o televisión, aceptaba cuanto se me presentaba, con lo cual empezaron a venir insatisfacciones artísticas, las cuales me llevaron a procurar ser muy cuidadoso con la selección de proyectos a futuro, sobre todo de teatro, ya 
que el cine y la televisión los consideraba un lenguaje aparte, más para subsistir económicamente hablando que para volcar inquietudes artísticas.

A la par de mi egreso del CUT, pedí a los maestros y maestra de mi clase favorita, acrobacia, si podía ayudarlos en algo o simplemente observar las clases de las generaciones más abajo que la mía.

Esto me llenaba de gozo al ver desde fuera lo que yo había vivido desde adentro, fijándome con detenimiento que podía ser más beneficioso para desarrollar el desempeño de cada estudiante en la clase.

Con lo cual me fueron asignando tareas, y a ser instruido en la génesis de los ejercicios, principalmente los profesores Dagoberto Gama, Raul Kaluriz, Gustavo Sánchez Parra y Mayra Serbulo, que son artistas y profesionales del área de cuerpo y movimiento.

Conforme fueron avanzando los meses y los años fui adquiriendo un poco más de herramientas pedagógicas de manera empírica. Y fui formando mi propio criterio hacia la enseñanza de la materia y la dirección que tenía que tomar.

Esto logro que fuera cambiando mi perspectiva de la materia, de cómo la impartían los otros maestros, los cuales tenían un enfoque más sobre habilidades corporales a aprender, como era el caso del maestro y acróbata fundador de la materia Raúl Kaluriz.

Esta metodología orillaba muchas veces a ejecutar ejercicios poniendo en riesgo la integridad física, creando una resistencia a la materia por parte de algunos estudiantes, lo que hacía evidente que no se pudieran aprovechar muchos elementos útiles de las clases.

Fue ese cambio de paradigma el que poco a poco fui introduciendo a la materia de acrobacia, el cual la maestra Mayra Serbulo ya había logrado introducir en la clase de acondicionamiento.

Y aunque no podría cambiar todo de tajo, dado que no era el maestro titular, lograba personalmente conversar y ayudar a algunas personas en esta materia, 
para que no se sintieran lanzados a realizar ejecuciones, que además de provocar miedo y rechazo, no se lograba una asimilación del aprendizaje que fuera a ser útil para la actuación.

Después de especializarme en teoría y metodología del entrenamiento deportivo en el centro de estudios deportivos en la UNAM en el 2017, pude hacer muchos puentes del deporte con la actuación y la forma en la que se aborda en las aulas.

Paso a ser un conocimiento empírico a otro basado en conocimiento del funcionamiento del cuerpo y el cerebro, los neurotransmisores, la generación de energía, las lesiones, los impulsos, la motricidad, los músculos, etc.

Y gracias a eso y al retiro del maestro titular a sus casi 80 años, pude tomar decisiones sobre la clase, y dar un giro radical a la forma de impartirla en las últimas cuatro décadas.

Como profesional, con mi grupo de teatro, festín efímero, puedo comprobar que las herramientas usadas en clase son útiles para cualquier tipo de montaje. No es solo una teoría, sino que lo llevamos a la práctica cada vez que estamos en proceso de montar un proyecto nuevo o en proceso de creación.

Me veo reflejado en mis alumnos y alumnas a la hora de enfrentar los distintos problemas a resolver, he estado en este lugar antes. $Y$ es a lo que trato de enfrentarlos en clase, poniendo de pretexto ejercicios físicos y acrobáticos a resolver y analizar, con lo cual ellos podrán generar los puentes a la hora de estar en la escena.

Consciente o inconscientemente veo como esos ejercicios desarrollados en clases emergen a la escena de alguna manera. $\mathrm{Y}$ no estoy hablando de realizar ejercicios acrobáticos en el aula, que pueden fortalecer el cuerpo. Me refiero a todos los otros elementos a veces intangibles, como la disciplina, el rigor, la memoria corporal, el arrojo, la concentración, el manejo de múltiples tareas al mismo tiempo, la conciencia con el compañero, el empuje, la garra, etc., tantas veces mencionados en esta investigación. 
Creo que en el CUT nunca se habían hecho preguntas sobre la pertinencia de la clase de acrobacia o de este tipo de entrenamiento en la escuela, creo que en México no se había puesto en tela de juicio ¿Porque las escuela de teatro tienen las clases que tienes? y ¿Porque las imparten los profesores que las imparten?

Razones de más para que en estos tiempos demos un vistazo al pasado, al presente y futuro de nuestra manera de impartir la clase, que tipo de escuela queremos tener, que clase de egresados necesita el teatro mexicano para afrontar los nuevos retos de la escena contemporánea. Y preguntarnos si las herramientas que proporcionamos en las escuelas siguen siendo vigentes o necesitan una restructuración.

Tengo la fiel creencia de que la revisión de la materia de acrobacia, que ahora me gusta más llamar entrenamiento físico, es importante, porque esta clase sigue siendo un pilar en la formación de las personas que pasan por las aulas del CUT y un distintivo que las personas de teatro en este país identifican en egresados del centro, por su disciplina, energía, compromiso y arrojo en escena.

Lo veo día con día en las clases, cómo podemos utilizar ejercicios y ejecuciones acrobáticas para poder abordar problemas con los que todo profesional se puede llegar a topar en un escenario o en las grabaciones.

Indiscutiblemente al realizar este tipo de entrenamiento podemos tener un abanico más alto de posibilidades corporales, intrínsecas al entrenamiento físico, que también serán una gran herramienta como los son las ya tanto mencionadas a lo largo de la investigación y no me canso de repetir: fuerza, destreza, resistencia, velocidad, coordinación, arrojo, control, autoevaluación, autocorrección, enfoque, generación de energía, dosificación de la energía, etc.

Como menciona la maestra Mayra Serbulo: 
Con cada nueva generación de actores y directores se establece una tendencia teatral de acuerdo con el contexto social, a los avances tecnológicos y los medios de comunicación. (SERBULO 2017) 24

A lo cual a mí me gustaría agregar la palabra "necesidades" a esta reflexión, ya que las necesidades de los estudiantes y profesionales de la actuación, no son las mismas que décadas atrás.

Los medios de producción han cambiado, las metodologías, los enfoques y los objetivos no son los mismos que años anteriores, la estética, la forma de dirigir y las exigencias actorales tampoco.

Entonces creo que no es posible seguir con una enseñanza basada solamente en el empirismo y la tradición, si no fundar las bases del entrenamiento de una manera sólida, individualizada y metodológica.

Ya no es suficiente decir "el entrenamiento funciona, hazlo". Creo que es necesario dotar a cada estudiante de un sentido crítico hacia lo que hace, orientarlo por el camino que vamos a transitar, para que de esa manera pueda aprovechar mejor las herramientas que la universidad le está otorgando para su profesionalización. Y convertir esas frases impositivas en expresiones mucho más metodológicas.

Cuando era alumno, si llegabas a preguntar ¿Por qué hacemos saltos gimnásticos o saltos mortales? Era muy común acallar la curiosidad legítima quien preguntaba diciendo "Porque es importante para el actor o actriz saber dominar y maniobrar su cuerpo". Y como aprendiz parecía algo bastante razonable, no cuestionar al maestro o a la maestra, pues es quien tiene los conocimientos.

Sin embargo después del cambio de paradigma que tuvo esta clase en los últimos años, tal pregunta siempre nos llevara a una respuesta desde el punto de

\footnotetext{
${ }^{24}$ SERBULO Mayra, Manual de entrenamiento físico sensible, Edigrafica, CDMX. 2017.
} 
vista actoral. Como artistas no solo tenemos que tener cierto control sobre nuestro cuerpo, tenemos que atender una serie de alertas sobre el trabajo actoral.

¿A que equivaldría ejecución de alto grado de dificultad, si lo comparamos con las acciones en escena? Uno podría responder: "A lo que sentimos antes de entrar a escena". Algún otro dirá "A la atención que tenemos que tener con los elementos que son parte de una puesta en escena: Texto, trazo, manejo de objetos, luz, música, acciones, etc." Otro más podrá agregar "A la atención o cuidado que tenemos con un compañero en escena"

Y creo que lo importante es la reflexión sobre el ejercicio, que era algo de lo que claramente se carecía en épocas pasadas, y resultaba más difícil para nosotros, como estudiantes sacar nuestras propias conclusiones. Ahora se invita a reflexionar más que a ejecutar.

En resumen, la reflexión y el cuestionamiento que se hacen durante las clases, debe ser permanentes. De lo contrario podría ser como un barco a la deriva sin conductor, o simplemente un acto de fe, creyendo que, en algún momento, lo que hagas en la universidad te servirá para convertirte en un profesional.

\subsection{Ejército, atletas y artistas ¿Que hacen? - Entrenan}

\section{El entrenamiento en mí como alumno, actor, maestro e investigador.}

Como alumno, algunas de las preguntas que siempre me hacía son:

¿Porque se debe entrenar? ¿Se ve sobre el escenario la diferencia de alguien entrenado y alguien que no lo está? ¿Qué clase de entrenamiento debe tener un estudiante de la carrera de actuación?

Siempre supe que para poder llegar a ciertas metas personales en lo actoral, vocal, corporal y expresivo, tenía que llevar un entrenamiento de cierta técnica o de ciertos ejercicios que me ayudaran a perfeccionar, pulir o dotarme de herramientas para enfrentar el personaje, ejercicio o secuencia de movimientos. 
La repetición, el análisis y la ejecución continua, formaban parte del camino a recorrer para llegar al resultado comprobable en escena.

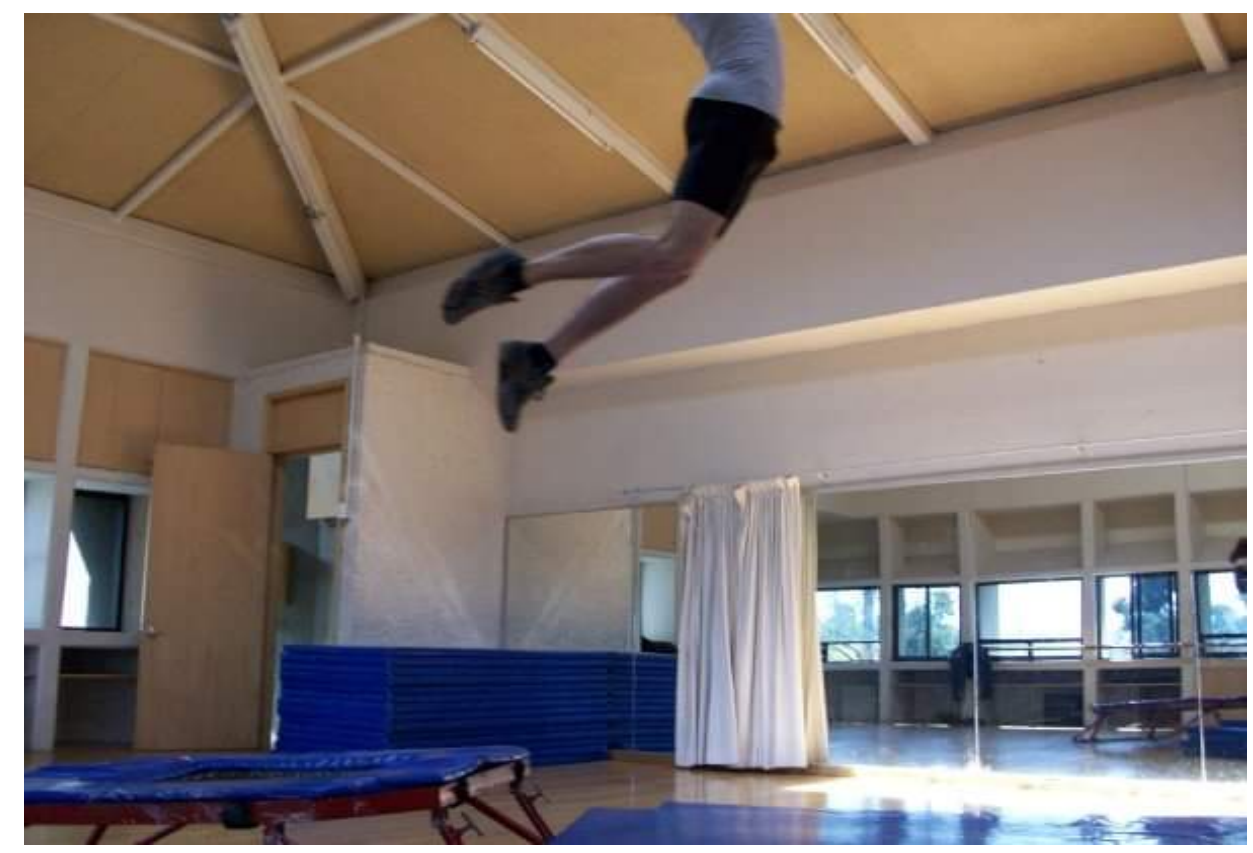

Foto 24. Salto con minitramp en arco

AP

Como actor profesional, esto no ha cambiado mucho, ya que para los montajes teatrales de la compañía a la que pertenezco, siempre nos hemos dado a la tarea de entrenarnos en técnicas específicas para poder alcanzar los requerimientos técnicos-actorales-expresivos que exige la puesta en escena en cuestión.

Esto con la finalidad de poder general niveles energéticos, expresivos y actorales de un alto grado dificultad, con los que el montaje en cuestión se auxilie para llevar al público mucho más claramente el sentir de los personajes, los símbolos y la historia que se quiere contar. 
En la obra La cabra o la fábula del niño y su doberman ${ }^{25}$ (2018), nosotros, los actores, nos sometimos a un entrenamiento exhaustivo de combate escénico militar cuerpo a cuerpo, para poder lograr un realismo en las secuencias de golpes, sin llegar a lastimar al compañero.

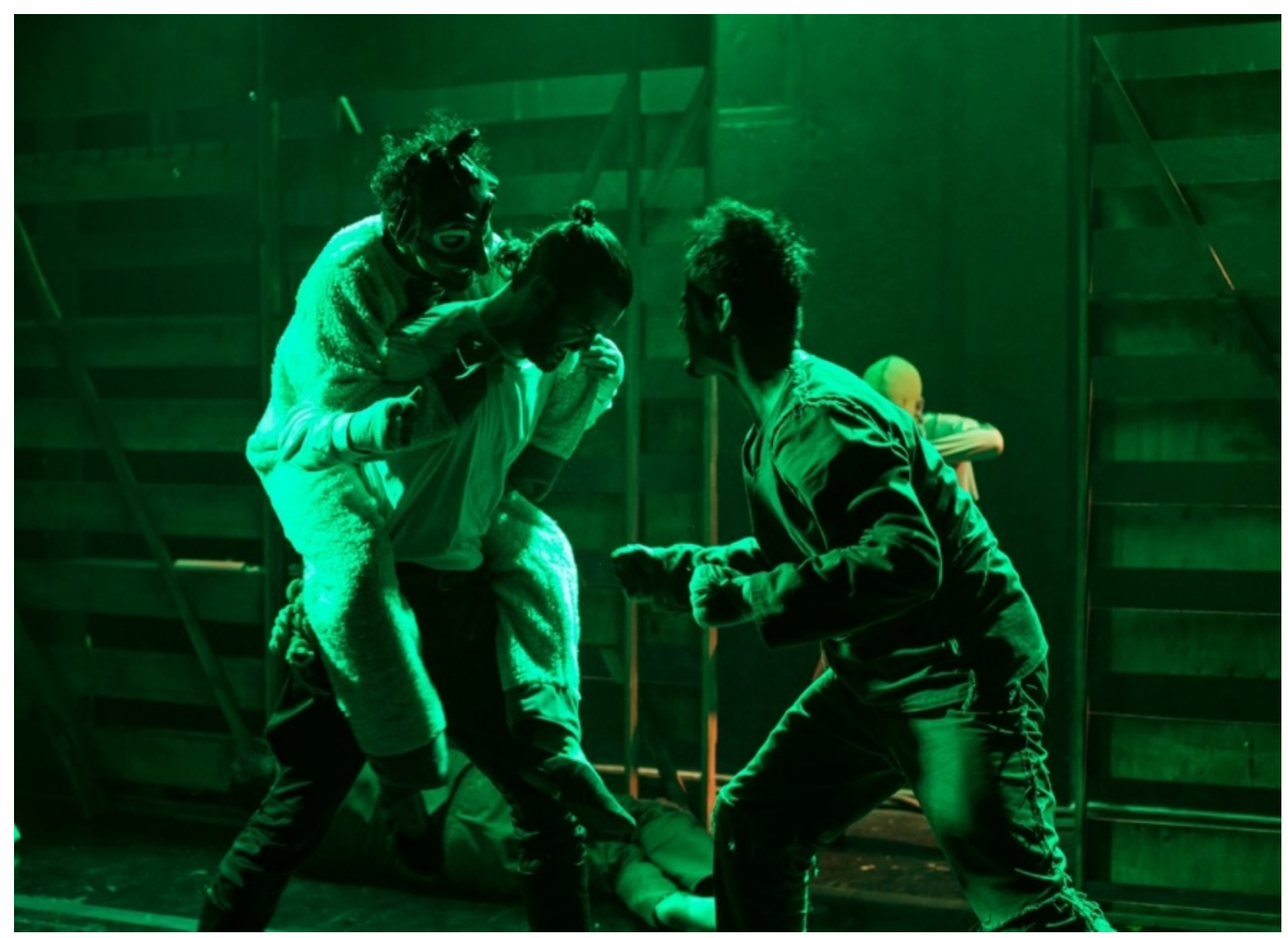

Foto 25. La cabra o la fábula del niño y su doberman, grupo Festín Efímero, 2018.

${ }^{25}$ https://www.youtube.com/watch?v=f5j9bxtNfJc\&t=2119s minuto 34:30 


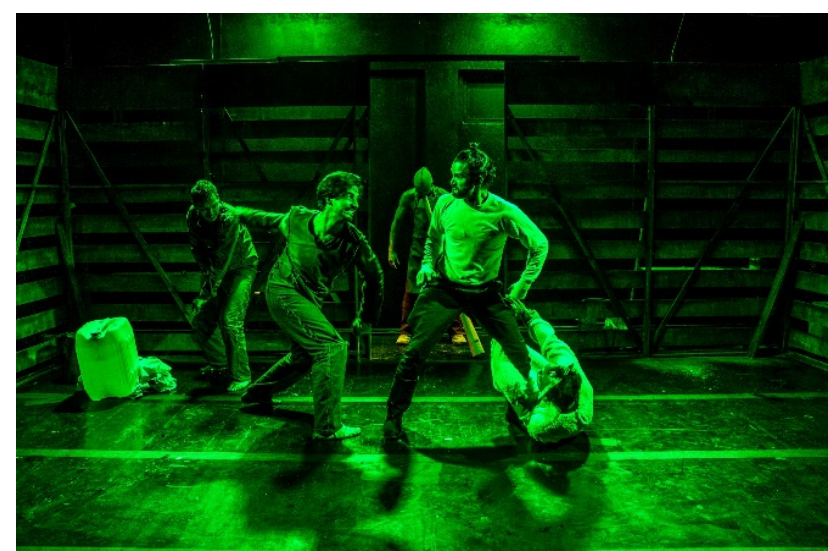

Foto $26 .^{26}$

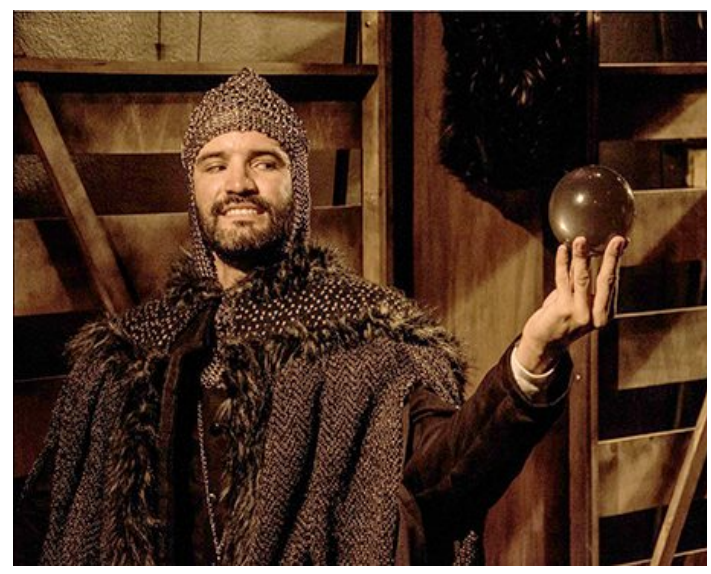

Foto 27.

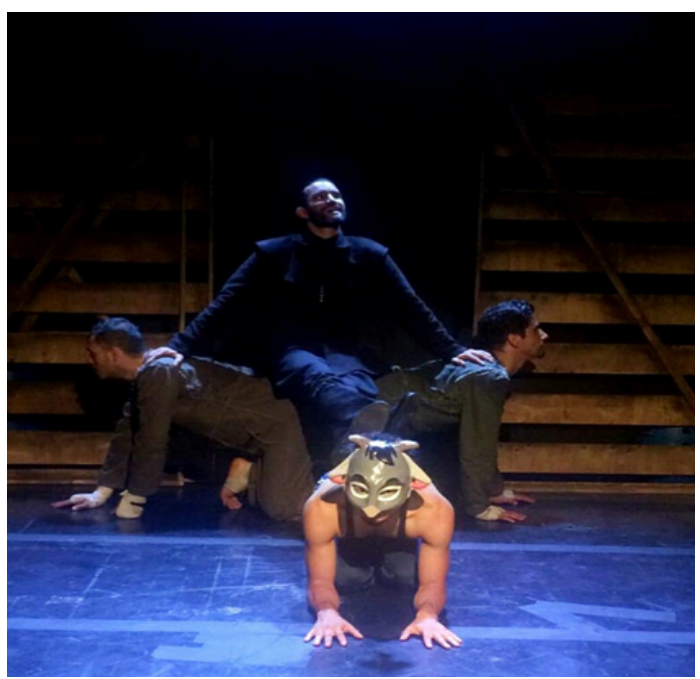

Foto 29.

\section{Foto 29}

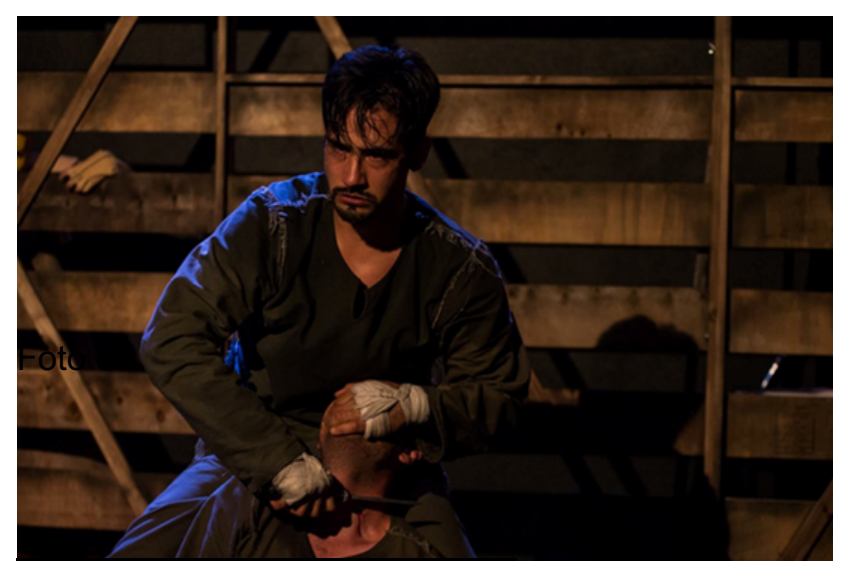

Foto 30 .

${ }^{26}$ Fotos 26 a 30. La cabra o la fábula del niño y su doberman, 2018 Festín Efímero. AP 
En la obra La escuela del dolor humano de Sechuán ${ }^{27} 2020$, los actores y actrices tuvieron un entrenamiento en la técnica vocal Roy Hart ${ }^{28}$ para poder realizar la pieza sonora hecha en el montaje, sacando al máximo el potencial de nuestras voces sin lastimarnos, haciendo funciones cinco días a la semana.

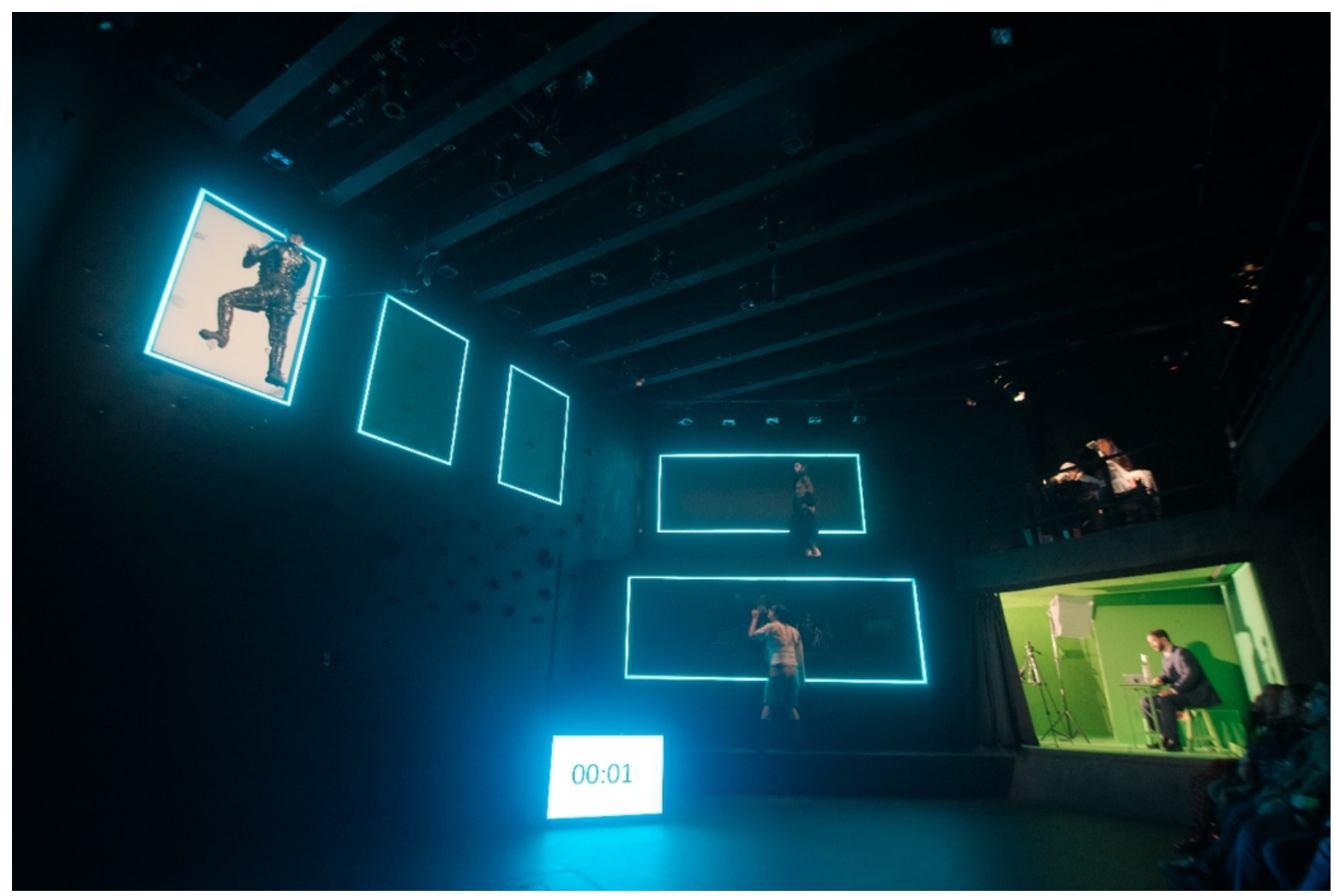

Foto 31. La escuela del dolor humano de Sechuán, Festín Efímero, 2020.

AP

${ }^{27}$ https://www.youtube.com/watch?v=mdmYo001Piw\&t=2676s minuto 40:20

${ }^{28}$ Técnica vocal que consiste en explorar la voz obscura, a partir del grito, el lamento, el retrato de la voz del alma y muchos ejercicios más de liberación vocal de una fuerza muy agresiva y poderosa. 


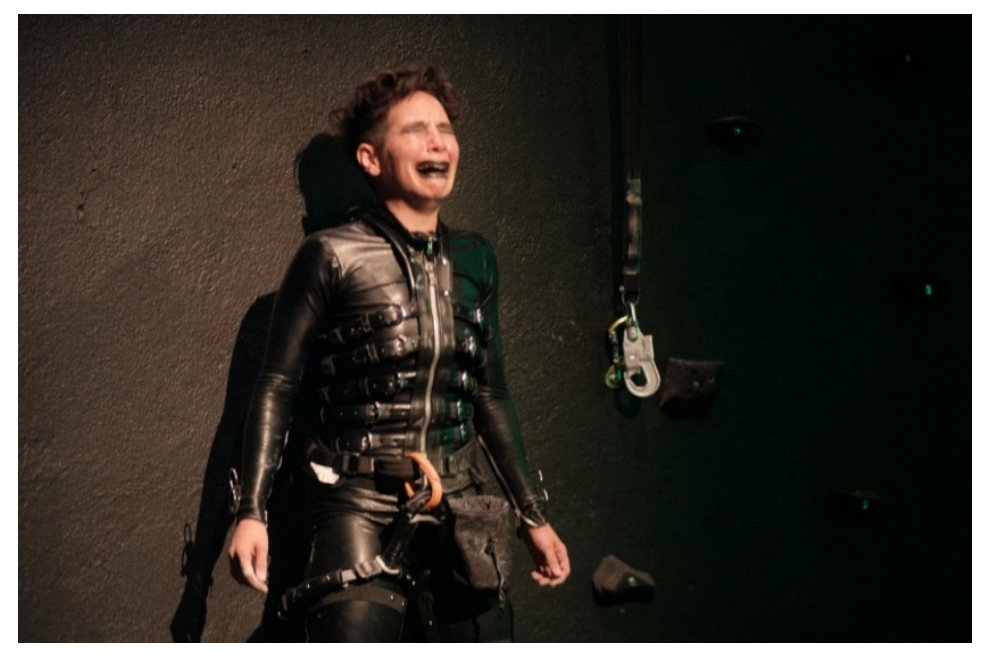

Foto $32 .{ }^{29}$

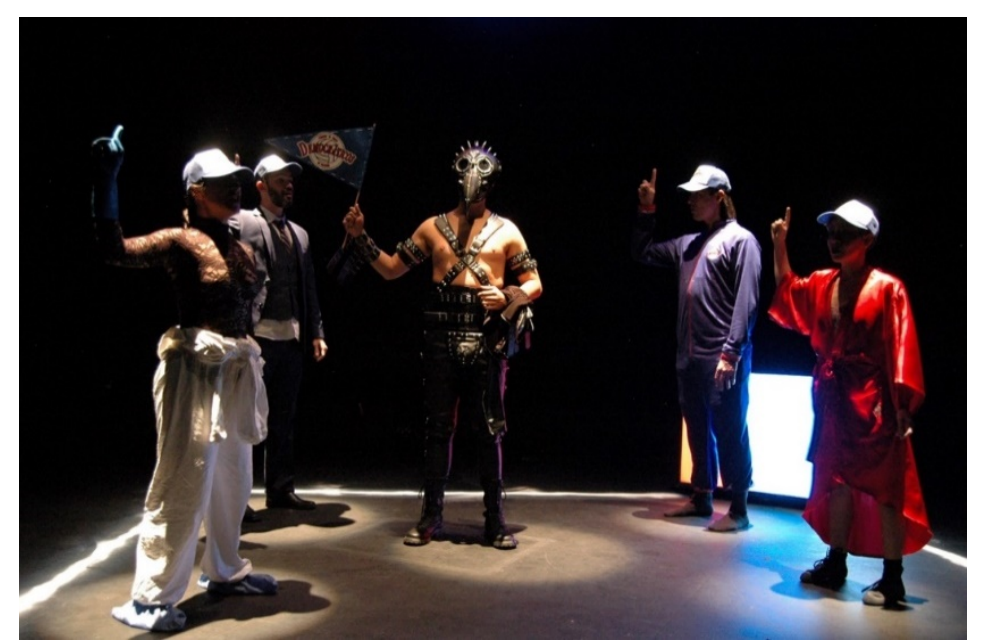

Foto 33.

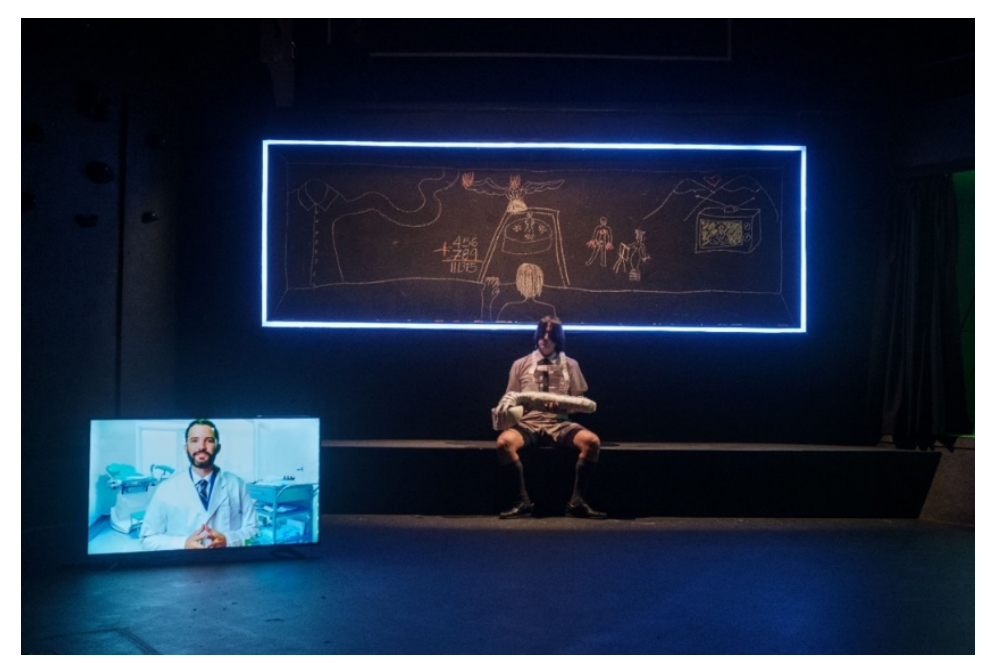

Foto 34 .

${ }^{29}$ Fotos 32 a 34. Obra La escuela del dolor humano de Sechuán, Festín Efímero, 2020 
El cuerpo, la voz, el análisis y la mente tienen que estar en un nivel donde se puedan explotar al máximo, siempre cuidando la seguridad, privilegiando la integridad y previniendo lesiones, para poder detonar la expresividad sin poner en peligro el cuerpo, la voz, la salud física y mental propia o de alguno de los compañeros de escena.

Como maestro e investigador, trato de que el entrenamiento que se lleva a cabo en el aula sea más allá de la actividad que realizamos; es decir, que sea un compendio de herramientas a elegir y desarrollar en sus actuales y futuros quehaceres artísticos de los estudiantes.

Los que cursan estas clases tienen historias corporales muy variadas, que van desde actividades deportivas y culturales en la niñez, hasta un total sedentarismo en su infancia y adolescencia; desde fuerza y elasticidad genéticamente heredada, hasta atrofia muscular, lesiones y condiciones musculo esqueléticas congénitas. De inicio se le provee a cada individuo de un seguimiento durante tres años para fortalecer su cuerpo y descubrir las posibilidades anatómicas del mismo.

Por otra parte, quizá la más importante, se hacen consientes similitudes que comparte esta materia con la clase de actuación y que estarán todo el tiempo presente en su trabajo profesional.

Muchas veces necesitaremos de entrenamientos específicos para cierto tipo de montajes, pero haber pasado por un entrenamiento de este tipo, mantendrá nuestra mente y cuerpo, que son nuestros principales instrumentos de trabajo, en condiciones que requiere esta profesión para llevarse a cabo. 


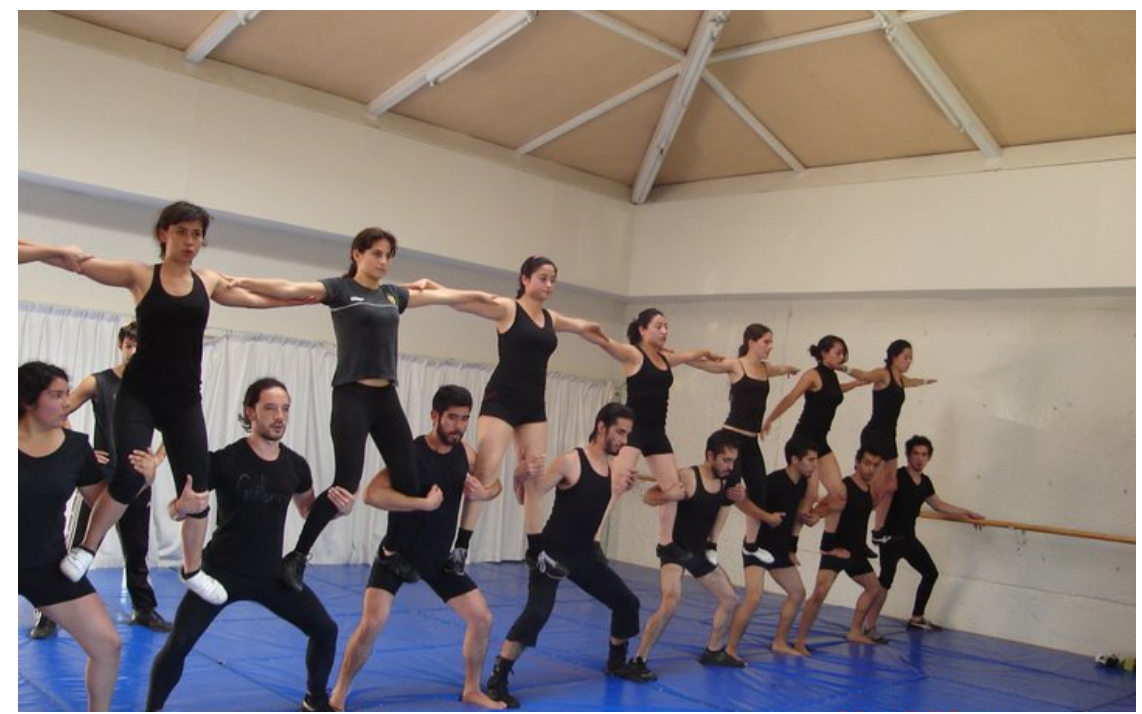

Foto 35 . Ejercicio de pirámide grupal

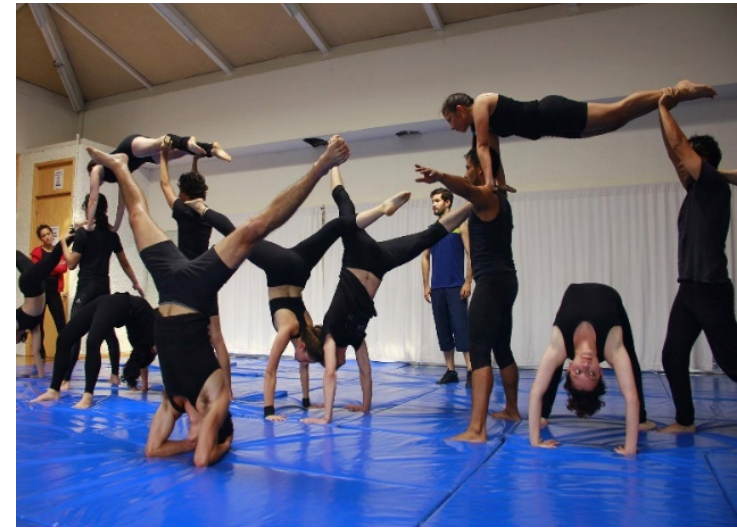

Foto 36. Ejercicio piramidal en grupo

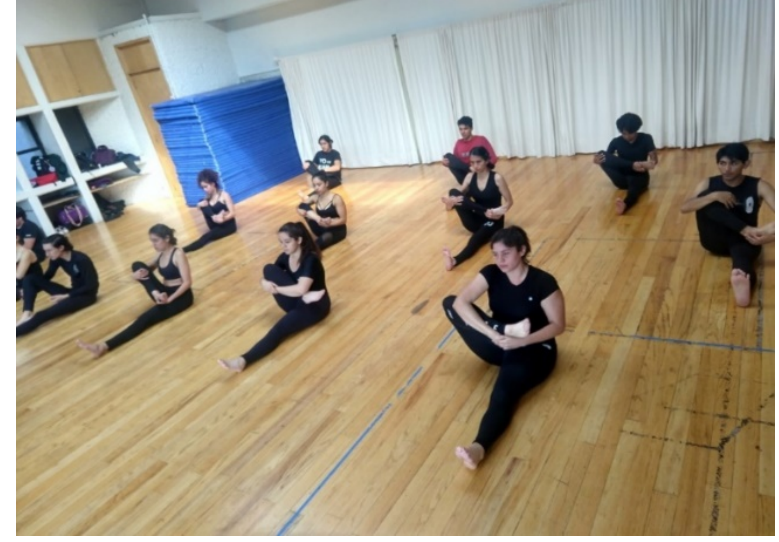

Foto 37. Calentamiento articular

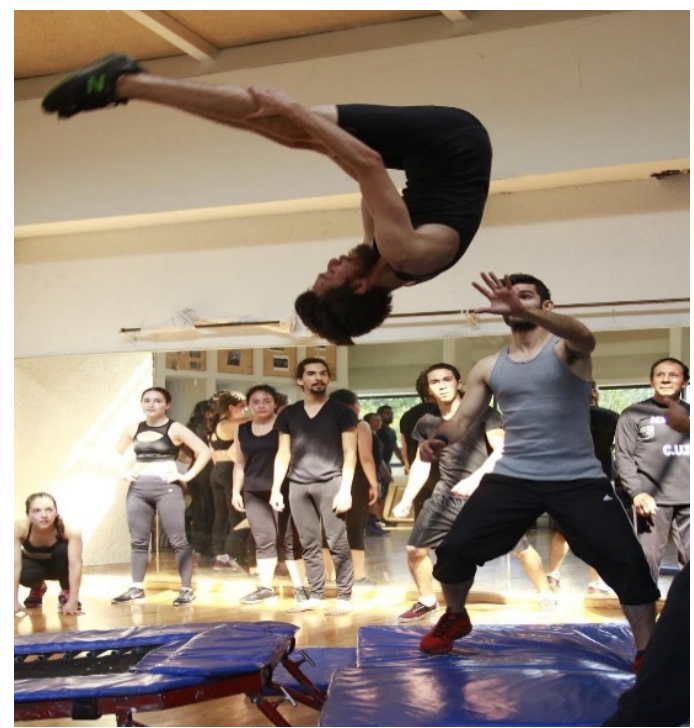

Foto 38. Salto mortal en escuadra sobre minitramp 


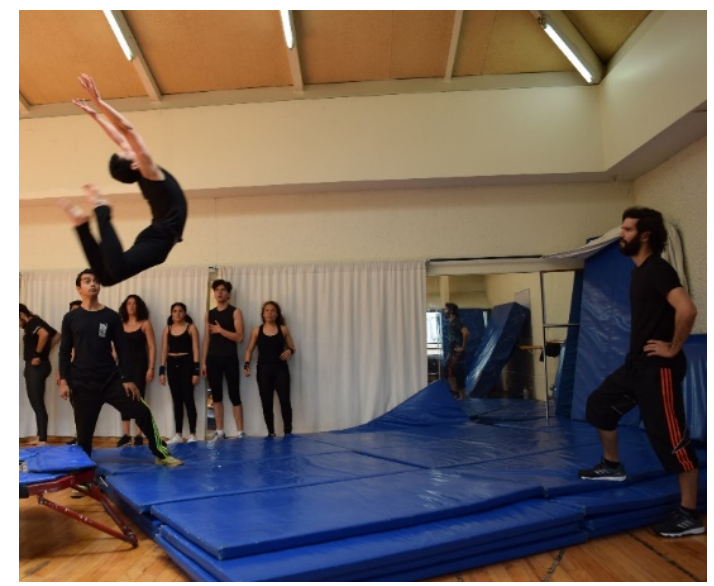

Foto 39. Salto longitudinal en arco

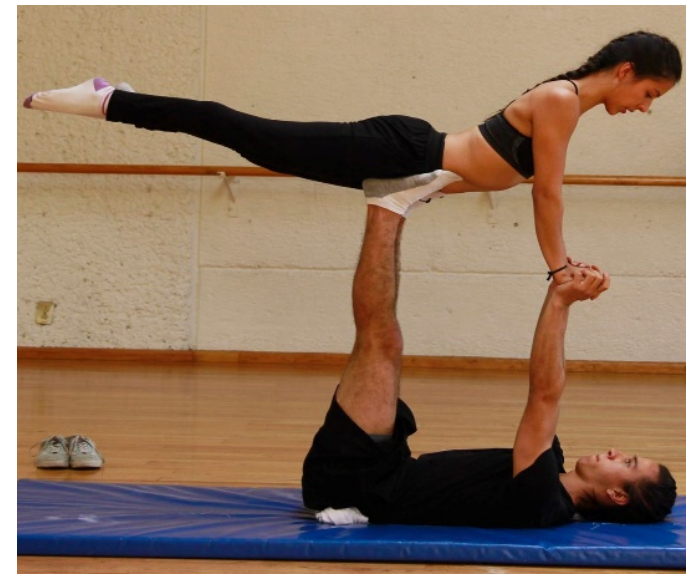

Foto 40. Ejercicio de equilibrio en pareja

Sería demasiado desastroso para un acróbata, tener miedo un instante antes de ejecutar su salto mortal u otro acto que arriesgue a la vida. En tales momentos no hay lugar para la indecisión, sin detenerse a reflexionar debe entregarse en manos del peligro y de su habilidad, eso es lo que debe hacer exactamente un actor cuando llega al punto culminante de su papel, el actor no puede detenerse a pensar, a dudar, a prepararse y probarse a sí mismo, debe actuar, debe salvar el salto a galope tendido"(STANISLAVSKI,1977) ${ }^{30}$

Lo que menciona Stanislavski en el párrafo anterior, no se refiere a la habilidad de poder realizar un salto con la ausencia del miedo y los nervios al momento de ejecutarlo.

Creo que se relaciona más con la habilidad de generar un mapa en el cerebro que se pueda utilizar para, consciente o inconscientemente algunas veces, seguir una ruta o un camino, los cuales pueda ayudar a desempeñar correctamente el oficio. Como ya dije antes no se trata de dominar el miedo, se trata de ir de la mano con él.

Además se ha mencionado en otras ocasiones el beneficio intrínseco que nos otorgan estos ejercicios, los cuales se ve reflejado en las condicionantes físicas (fuerza, elasticidad, resistencia y velocidad).

\footnotetext{
${ }^{30}$ STANISLAVSKI, Konstantín Manual del actor. Editorial Diana, México DF. 1977
} 
Como menciona el propio Stanislavski:

Los músculos flácidos la postura viciada los pechos caídos. Los vemos todo el tiempo en torno a nosotros demostrando un inadecuado instrumento físico, tal vez esto no importa en la vida ordinaria pero cuando pisamos un escenario muchas veces se necesita un aparato físico más móvil flexible expresivo y sensitivo.(STANISLAVKI 1977) $)^{31}$

Lo cual, en mi opinión, no nos garantiza como resultado una interpretación magnífica, de hecho, he llegado a ver muchos actores y actrices con cuerpos virtuosos, pero que no expresan absolutamente nada, vacíos.

Aun así, tengo la idea de que alguien con un entrenamiento físico dedicado a mantener todas las características que menciona Stanislavski, será alguien con un cuerpo más expresivo, dúctil y lleno de energía en escena.

Este mapeo del que hablo, es una parte esencial para entender la importancia de la acrobacia como parte del entrenamiento físico, y de cualquier entrenamiento enfocado a la actuación, ya sea danza, esgrima, artes marciales, etc.

La característica distintiva de un cerebro como el nuestro es su impresionante habilidad para crear mapas, el mapeo es esencial para una gestión compleja. Mapear y generar vida van de la mano cuando el cerebro produce mapas se informa asimismo las informaciones contenidas en los mapas pueden usarse de modo no consciente para guiar con eficacia el comportamiento motriz"(BASTOS, 2017)

Muchos de los objetivos del entrenamiento físico con enfoque actoral que se trabaja en el CUT va de la mano con esta idea, ya que lo que pretendemos, como se ha dicho antes, no es ser ejecutantes de acciones que nos lleven al virtuosismo corporal o que nos haga caer en los principios deportivos y competitivos esenciales, más rápido, más alto, más fuerte; sino tratar de generar un mapeo cerebral que nos

\footnotetext{
${ }^{31}$ STANISLAVSKI, Konstantín. Manual del actor. Editorial Diana, 1977

${ }^{32}$ BASTOS, Helena, Cuerpo sin voluntad. Cooperativa Paulista de Dança, Sao Paulo. 2017
} 
ayude a traducir estas experiencias antinaturales o artificiales en prácticas actorales orgánicas, tal como las viviremos en escena.

¿Cómo podemos navegar con el estrés, la resistencia y el temor de ejecutar un salto? Riesgo, estrés y miedo son similares en eventos escénicos como: estar en el escenario, hacer una secuencia física de gran dificultad o atravesar un momento de gran intensidad emocional.

Aunque son cosas relativamente muy distintas, mi experiencia y en la de otros, habla de un sentimiento muy similar en ambas circunstancias.

\subsection{Inspección de la tradición, el comienzo del conocimiento corporal.}

El nuevo enfoque y proceso de la clase de entrenamiento físico, intenta que el porcentaje de ejecución acrobática, así como ejercicios relacionados con esa disciplina que se realizaba con anterioridad, sean menores. También lograr que se haga más énfasis en un análisis de los ejercicios que se ejecutan, para así extraer las analogías y metáforas que se necesitan como herramienta y a las que se enfrentan en la escena.

Por ejemplo: cuando alguien está por realizar un ejercicio acrobático de alta dificultad, analizamos la acción y hacemos una analogía con un hecho escénico, en este caso, comparamos un salto mortal con salir por primera vez a escena durante una obra.

No se trata de controlar lo que se siente, si no navegar con ello y hacerlo parte de manera positiva para que nos empuje a realizar nuestro objetivo, así como de estar listos con la energía necesaria.

Para esto los alumnos y las alumnas necesitan concentración, enfoque, haber ensayado lo que va a hacer, fuerza, recordar la técnica, etc.

Pero al mismo tiempo también cargarla de esencia para poder realizar el ejercicio no solo como un ejercicio acrobático, lo cual no tendría tanto valor. 
En este caso no importa si se realiza bien o mal, si no el enfrentamiento ante el obstáculo, el temor, el vacío.

Realizar algo que cuesta trabajo, así el inconsciente de las personas sabe que puede enfrentar y salir avante ante esos impedimentos, al igual que conocer que herramientas puede utilizar para poder viajar por esos momentos de duda.

Otro ejemplo, son las herramientas que intentamos fomentar, como la autocorrección de los ejercicios, con la cual el estudiante se da cuenta de las fallas técnicas que está cometiendo en los ejercicios, gracias a su análisis y autocritica.

Muchas veces esto es comparado, por el mismo alumnado, con las clases de actuación, cuando se les dan varias veces las mismas notas a corregir y no son capaces de darse cuenta que es lo que no funciona de lo que están probando.

Este tipo de entrenamiento pretende hacer más perspicaz a los estudiantes, para darse cuenta por si solo que puede cambiar en su ejecución, la cual no importa si es buena o mala, pero técnicamente lo importante es que sepa que puede mejorar cambiando pequeños movimientos mejorando la ejecución, esto hace que inconscientemente el cerebro tenga la capacidad de cambio cuando se le refiere que algo no está saliendo como es esperado.

Cómo podemos ver, se trata de un entrenamiento más de la mente que del cuerpo. Aunque el cuerpo quedará entrenado indirectamente, elástico, con fuerza, resistencia y velocidad, al igual que cardiovascularmente, elementos muy útiles y usados para la escena, como se ha visto en los montajes de titulación en los últimos años del CUT:

- Palinuro en la escalera, 2018

- Straight, 2019

- Ya no sé qué hacer conmigo, 2020

Los cuales son exámenes finales de cada generación, en las cuales se empezó a aplicar el cambio de paradigma en la clase de acondicionamiento físico y acrobacia. 
Y donde se muestra, además de un despliegue corporal amplio, el tipo de entrenamiento indirecto que generan en sus instrumentos de trabajo, además de un avance palpable en su presencia, condición física y desarrollo de su cuerpo sobre la escena. Todo esto gracias a las herramientas adquiridas, seleccionadas y aplicadas por cada uno de los estudiantes durante los tres años de entrenamiento.

Con lo que podemos aseverar que el nuevo planteamiento de la clase en los últimos años ha funcionado, ya que reafirma la importancia de que no se perciba la clase como en décadas anteriores, con el objetivo de fortalecer un cuerpo y hacerlo capaz de realizar ejercicio, resistencia o suertes acrobáticas en escena.

Ahora el planteamiento principal es hacer metáforas y analogías de los ejercicios a realizar en clase con los que se hacen en la clase de actuación o con los que se realizarán al momento de sus montajes de titulación.

Uno de los errores que se cometía continuamente en años anteriores al cambio, es la homologación del entrenamiento y de los cuerpos, lo cual creo que es un desacierto, ya que al no formar deportistas si no artistas, la historia corporal, social, nutricional, afectiva, física etc. De cada uno de los individuos, hace esto un trabajo no solo imposible si no contraproducente y arriesgado.

Un ejemplo en el que podemos ver palpablemente la importancia del entrenamiento que ha llevado el alumnado en sus tres años de entrenamiento físico, es la llegada de estudiantes de otras escuelas ya sea nacionales o extranjeras en el segundo y tercer año en el CUT.

Con lo cual vemos los diferentes tipos de entrenamiento en otras instituciones y su funcionamiento en una dirección u otra, ya sea, cómo enfrentan las personas de intercambio las materias del CUT o como es la presencia escénica de los estudiantes regulares del CUT. ¿Es distinto del cuerpo de alguien que no ha llevado el mismo tipo entrenamiento?

En entrevista con un alumno de intercambio de Santiago de Chile, menciona como la actividad acrobática, del modo en que se vive y se le da el enfoque en el CUT cambia su percepción del entrenamiento corporal, ya que siempre lo vio como un camino para llegar a la ejecución y no para ser orientado a la parte actoral de su preparación. 
Viendo esta misma situación del lado contrario podemos ver a los miembros de otras escuelas nacionales, donde entrenamiento físico se tiene abandonado por completo, provoca que el trabajo corporal en su estadía en el CUT no sea prioridad, evitando la clase del área cuerpo y movimiento a como dé lugar.

Como resultado vemos una clara diferencia corporal y energética en sus exámenes de otras materias, comparando con las herramientas que adquirieron los estudiantes que si cursan ese tipo de clases.

Con esto no quiero decir que los actores y actrices en formación que cursan las clases del área de cuerpo y movimiento en el CUT presentan performances mejores que los que no la cursan, o que un estudiante de otra escuela será artísticamente inferior que los del CUT, por tener distintas clases y enfoques académicos. La reflexión va más encaminada a verificar que el entrenamiento físico es una herramienta de mucha utilidad, que ayuda a que los cuerpos adquieran ciertas características que los auxilian al momento de estar en escena.

Y resaltar por otro lado la falta de investigación sobre el tema, ya que muchas escuelas de actuación, así como muchos maestros y maestras de materias de cuerpo y movimiento que no muestran interés en realizar investigaciones sobre sus prácticas.

En muchas ocasiones se usa un método de entrenamiento sin preguntarse si es de acuerdo al perfil de egreso de las personas que se quiere formar, si es factible ese entrenamiento o siquiera preguntarse porque se eligió esa preparación en años o décadas anteriores.

Siempre se debería analizar si se usan solo porque los rusos, polacos y daneses decían a principios de siglo y en los años sesenta que así debía de ser esto, o porque en verdad es un instrumento útil, del cual se ha investigado e invertido tiempo en comprobar si funciona como herramienta y se tienen bases sólidas para demostrarlo. 


\subsubsection{Artistas con entrenamiento físico en las venas}

En los últimos años se ha optado por la individualización del entrenamiento, lo cual nos hace enfocarnos en las oportunidades que cada sujeto puede aprovechar en su proceso, sin importar su edad, condición social, peso, historia corporal, historia de enfermedades y demás factores que pudiera afectar su cuerpo en esta clase de entrenamiento.

Al ser un actor en activo y pedagogo, puedo comprobar con mis compañeros actores y actrices de diferentes proyectos, al igual que con el alumnado, si lo que hemos hecho en los últimos años ha funcionado.

Dominando un lenguaje común, corporalmente hablando, es sabido de lo que son capaces las personas que invitamos a participar en nuestros montajes, y cómo podemos esperar de ellos ciertas herramientas, al haber pasado por el mismo proceso. Sabemos de qué manera emplearlo y sobre todo lo que funciona.

Me ha resultado muy grato en los últimos tres montajes de la compañía Festín efímero, el hecho de que hemos contado con ex alumnos y ex alumnas de generaciones recientes al igual que de generaciones más antiguas. Esto representa una ventaja ante las formas y tiempos de producción con que los montajes teatrales funcionan en este país.

\subsubsection{Festín Efímero}

Compañía formada en el año de 2014 por Guillermo Revilla, Héctor Iván González y yo, Edgar Valadez, a partir del aspiración de realizar un montaje y explorar la puesta en escena de una dramaturgia propia, basados en el deseo de hablar sobre temáticas personales, estéticas alternativas y técnicas corporales que pudieran abonar a una forma lúdica y profunda de ver el teatro. 
Su primer proyecto Pozole o la venganza de los anacronidas es la historia de tres hermanos cocineros del platillo típico mexicano, el pozole, relacionado también con la desaparición de victimas del narcotráfico, dado que el término "pozolear" es una técnica que se usa para desaparecer cuerpos con soda cáustica.

Estos hermanos se reúnen para una cena muy especial, ahora que el padre está ausente. Basados en el mito griego de Cronos, se usan saltos en el tiempo para ver la relación de los hermano en su niñez, adolescencia y vida adulta. Los juegos de baile, acrobacia y combate nos llevan a un desenlace fatal, donde solo quedaba vivo el hermano que el público decidía.

En este primer montaje escrito, dirigido y actuado por los tres integrantes de la compañía, pudimos explorar todas las herramientas aprendidas en el CUT, ya que los tres somos egresados del centro. La corporalidad formaba una base esencial del montaje, ya que exploramos tanto la acrobacia como el combate escénico y el baile para poder hacer transiciones, poder reforzar el discurso y la relación de los hermanos.

Con cincuenta y seis funciones y giras nacionales e internacionales al festival de artes escénicas de Rabat Marruecos, este primer montaje representó una llegada a la escena teatral nacional como grupo con énfasis corporal característico.

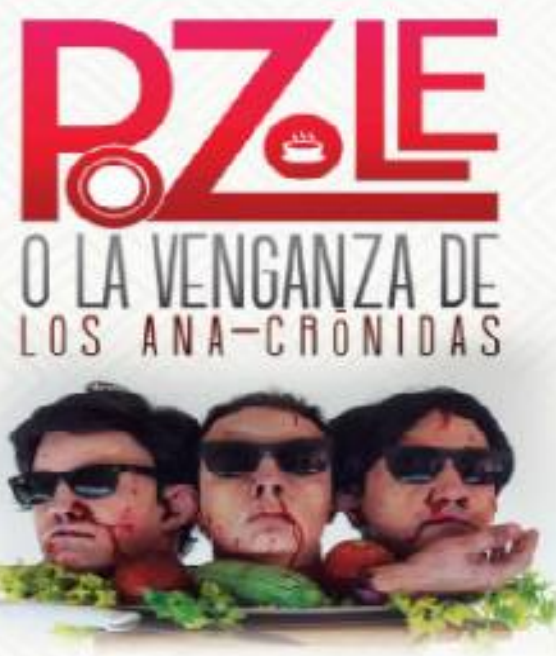

Foto 41.33

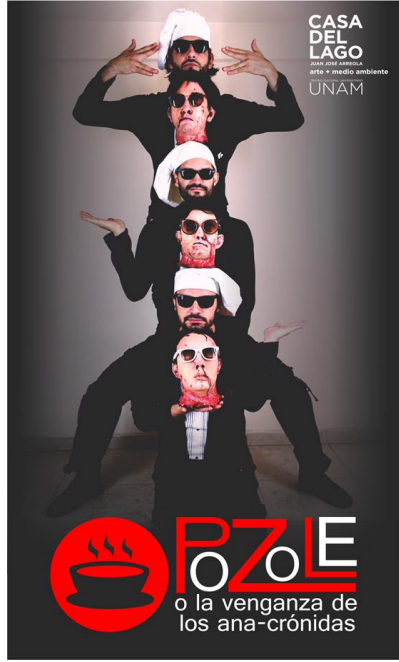

Foto 42.

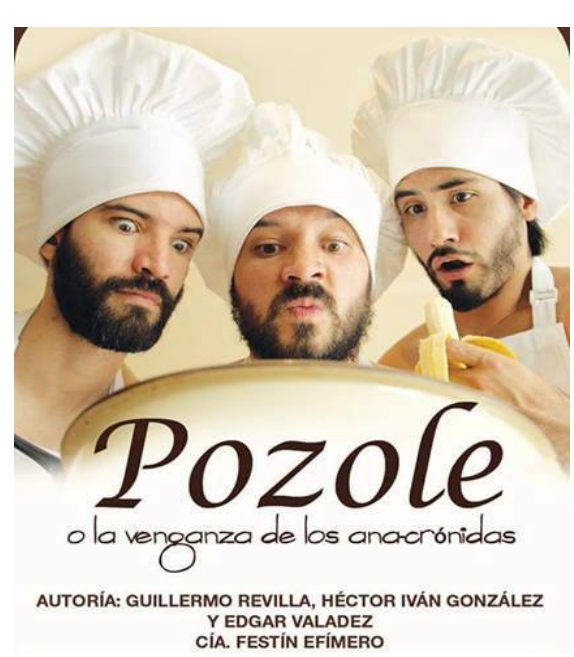

Foto 43

\footnotetext{
${ }^{33}$ Fotos 41 a 43. Programas de mano de las distintas temporadas de la obra Pozole.
} 


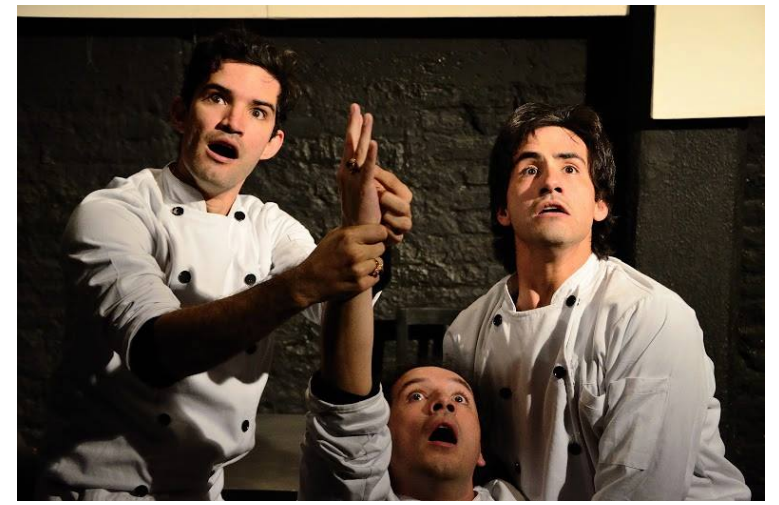

Foto $44 .{ }^{34}$

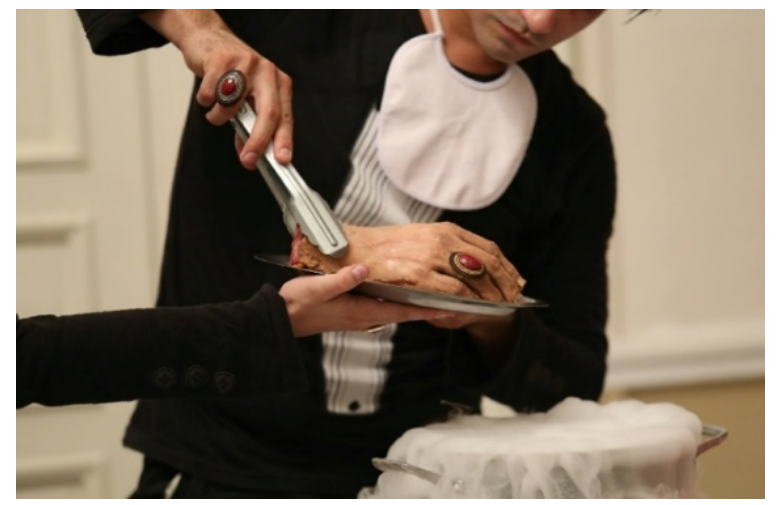

Foto 45.

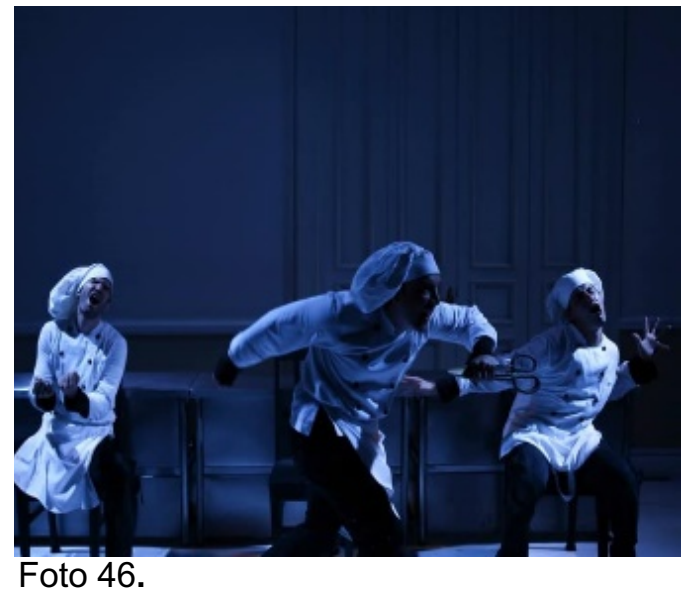

La cabra o la fábula del niño y su doberman

Esta historia habla sobre la desaparición de personas en México y los métodos de entrenamiento que utiliza el narcotráfico para reclutar y amaestrar a sus sicarios, basándonos en el entrenamiento "Caibil" de elites del ejército guatemalteco, donde a dos candidatos se les entrega una cabra y todos tienen que sobrevivir o todos morirán.

En el año 2015 se integran al grupo, Tania María Muñoz y José Juan Sánchez, también ex estudiantes del centro, se empieza a trabajar en el montaje La cabra o la fábula del niño y su doberman. Escrita por Guillermo Revilla, actor,

\footnotetext{
${ }^{34}$ Fotos 44 a 46. Fotos de escenas de la obra Pozole. Archivo personal
} 
director y fundador de la compañía Festín Efímero, quien también dirigió este montaje, actuaron en el montaje, los otros miembros de la compañía - Héctor González, Edgar Valadez - y un actor invitado Rodrigo Castañón, egresado del CUT generación 2014-2018.

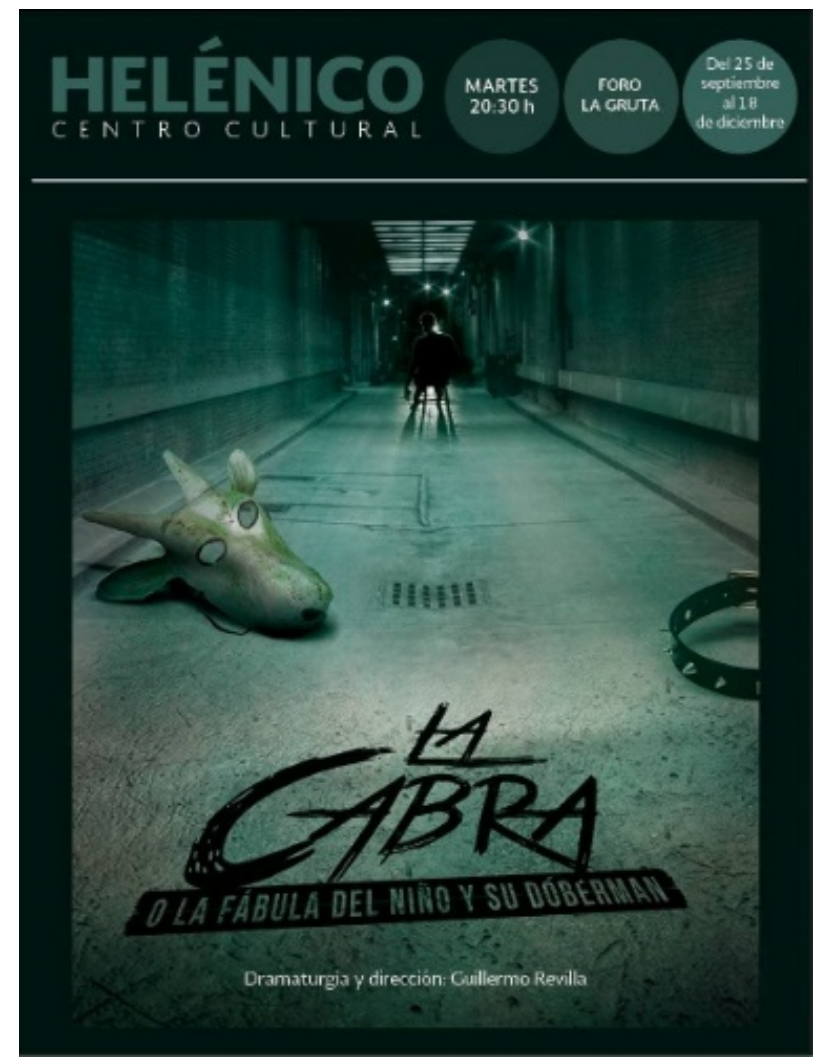

Foto 47. Programa de La cabra.

Para este montaje el equipo tuvo que se someter a un entrenamiento arduo de combate escénico de contacto, con un especialista en la materia, ya que pretendíamos hacer las peleas y los golpes lo más verosímiles posibles, para reforzar el sentimiento de crueldad al que son sometidos los raptados por los grupos delictivos mexicanos.

Gracias al entrenamiento y siendo fieles a una estética gore, la corporalidad como lenguaje, al juego y al absurdo, se pudo fortalecer la idea estética y el lenguaje escénico que el grupo planteo desde el primer montaje, con lo que se empezó a distinguir al grupo en la escena mexicana. 


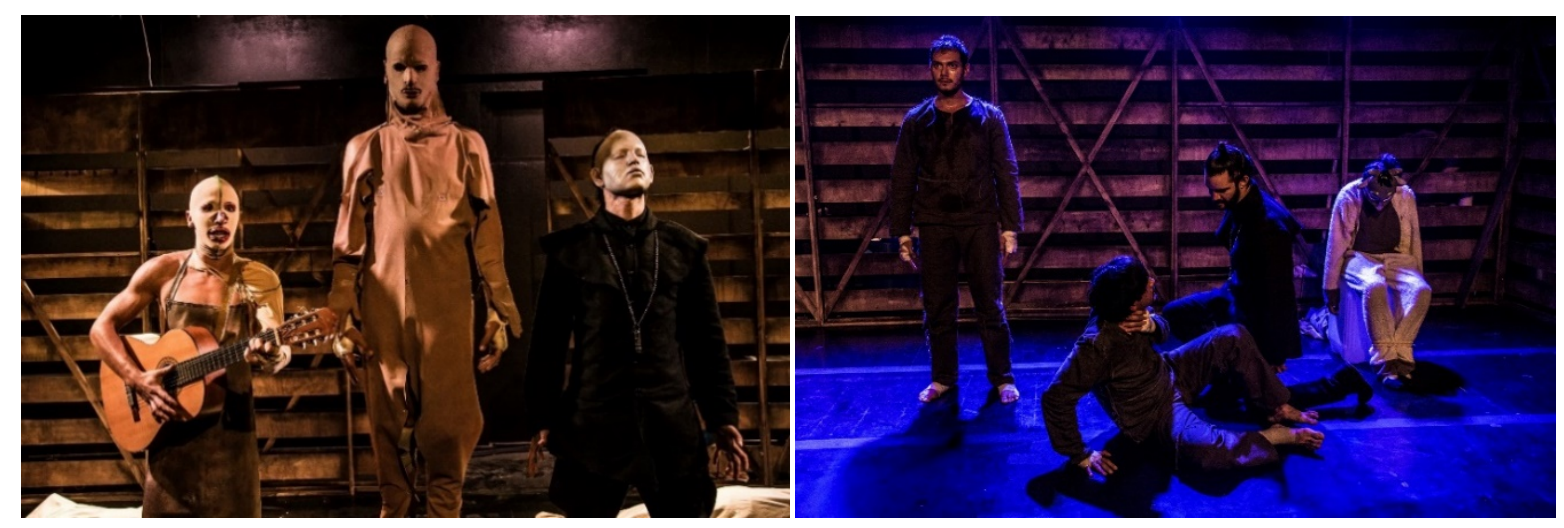

Foto $48 .{ }^{35}$

Foto 49.

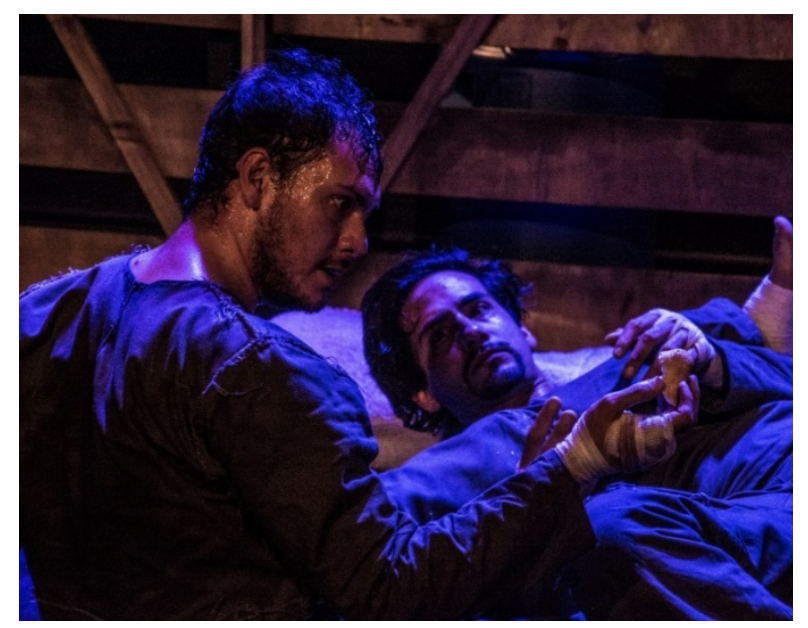

Foto 50.

Noches de combate

Cada año desde hace doce años se lleva acabo La noche de combate escénico en la ciudad de México, la cual consiste en pequeñas escenas teatrales que involucren el combate escénico como base detonadora del conflicto.

El grupo Festín Efímero ha participado en cuatro ocasiones con distintas escenas de combate, que al igual que sus montajes se basan en el absurdo, el juego y la potencia de la corporalidad para llevarse a cabo.

Gracias a eso hemos sido considerados año con año para participar, debido al buen manejo de la técnica, dramaturgia de las escenas y propuesta corporal que hemos puesto a cada una de las escenas de los últimos años.

\footnotetext{
${ }^{35}$ Fotos 48 a 50, fotos de la obra La cabra ola fábula del niño y su doberman. AP.
} 


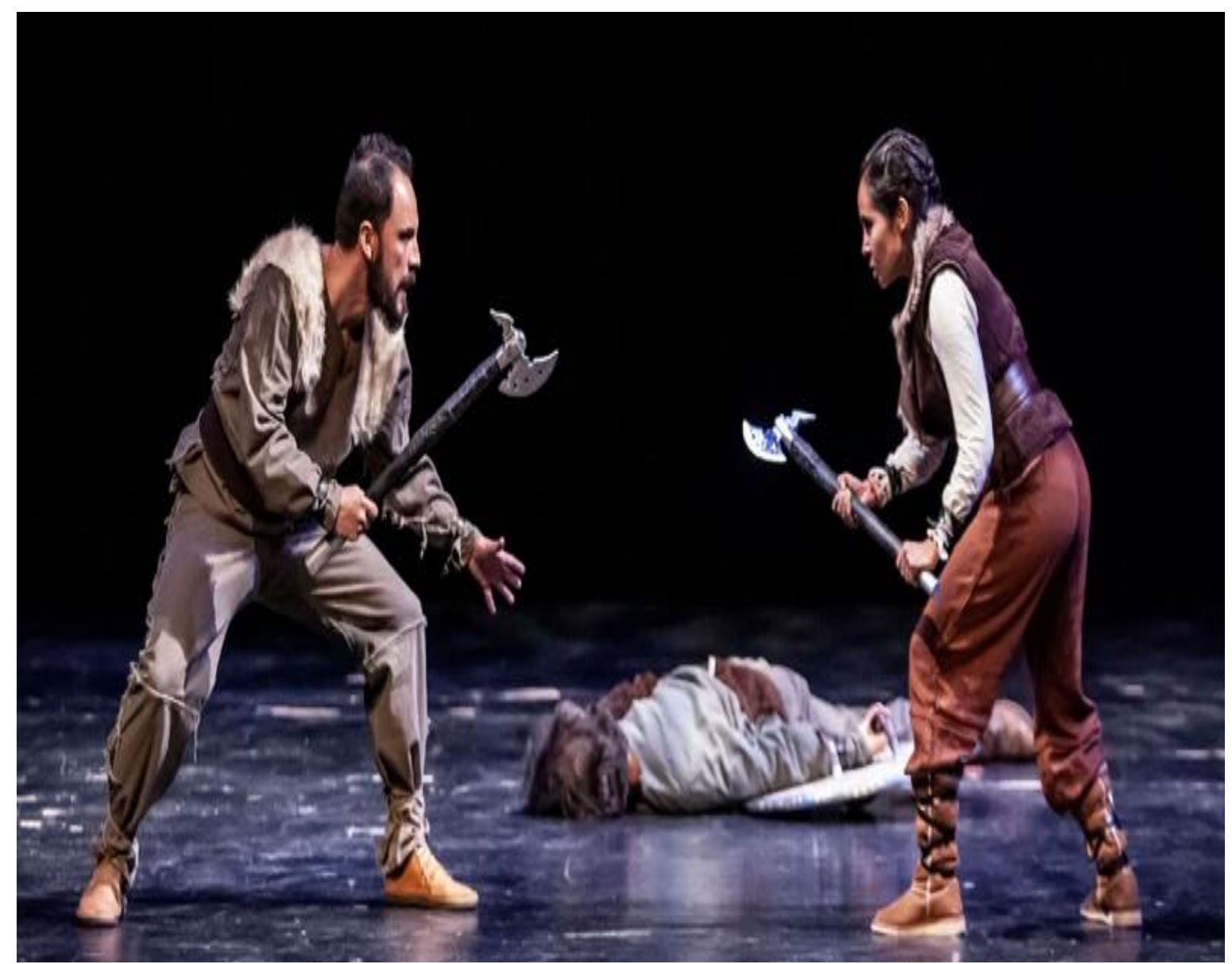

Foto 51. Escena de La XI noche de combate, Festín Efímero, 2019.

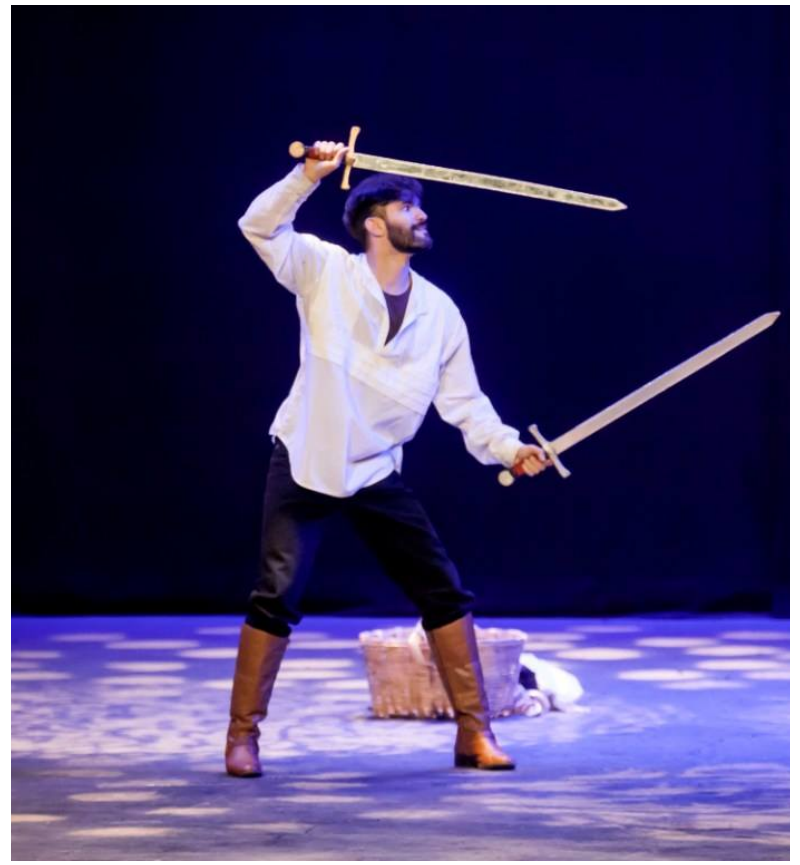

Foto $52 .{ }^{36}$

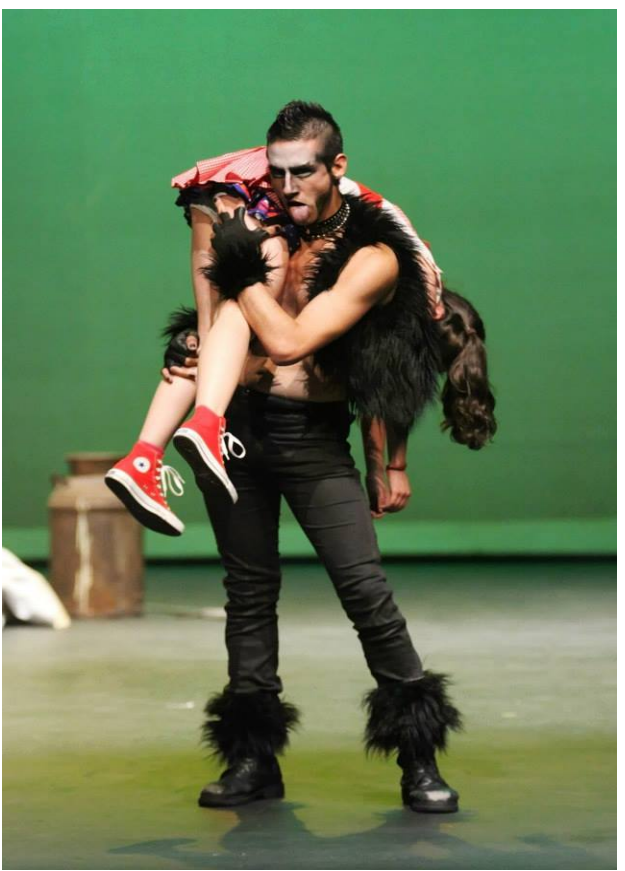

Foto 53.

${ }^{36}$ Fotos 52 y 53. Fotos de las distintas Noches de combate, Compañía Festín Efímero. AP 


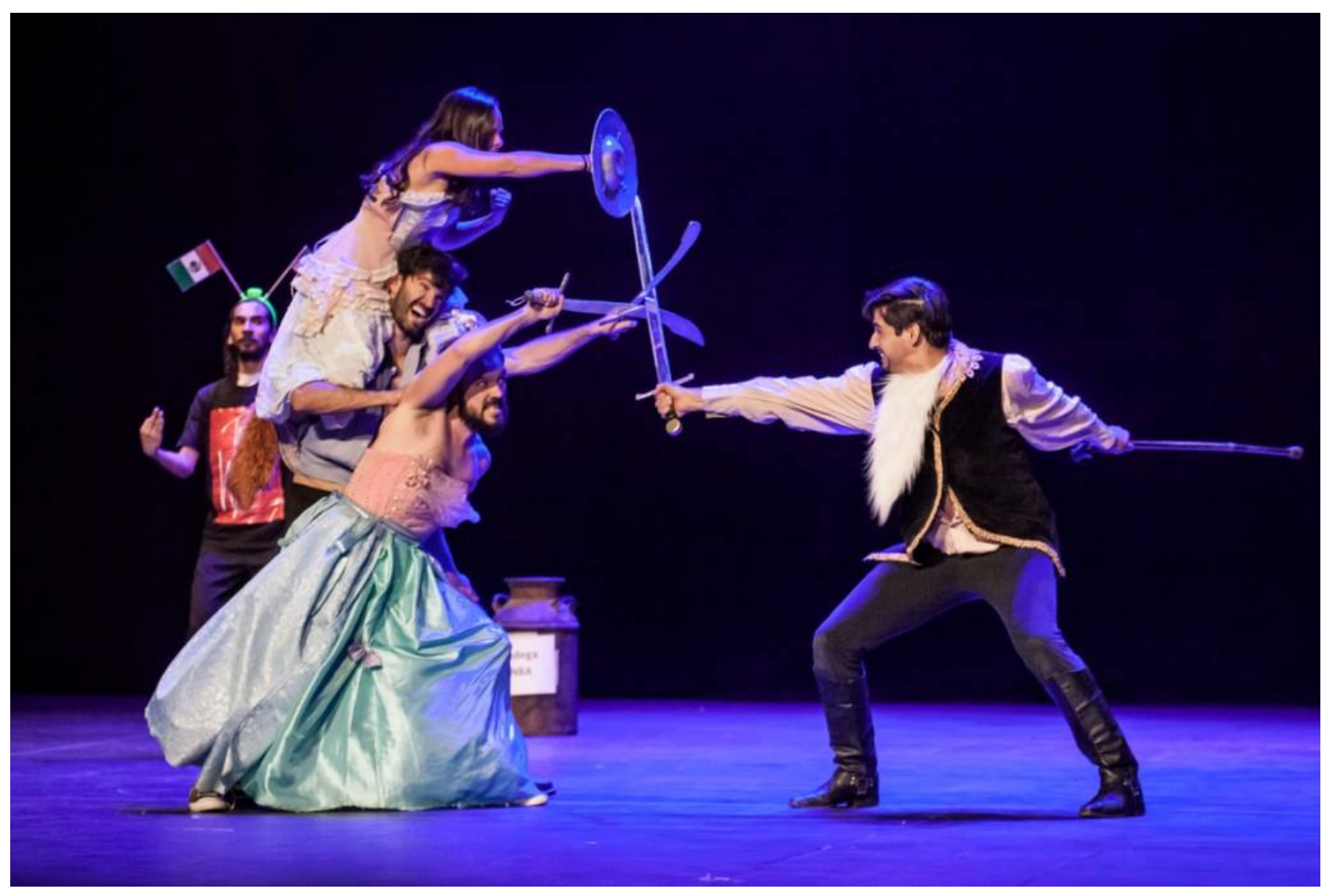

Foto 54. Escena de la IX noche de combate. Festín Efímero 2017.

AP

\section{La escuela del dolor humano de Sechuán}

Relata las historias de seres anómalos con cuerpos extraordinarios (mutilados, deformes, enfermos) que habitan un lejano país donde el dolor de los ciudadanos se ha transformado en una tragedia en común.

En la escuela del dolor humano de Sechuán, se optó, al igual que en otros montajes, por conservar una estética enrarecida. Entrenar bajo el régimen de una técnica y conservar el desenvolvimiento corporal como lenguaje escénico principal, con el apoyo de multimedia y de la tecnología. Al igual que en montajes pasados invitamos a alguien externo al grupo a participar en el montaje.

Este montaje ha resultado hasta ahora el más complicado y de mayor reto para la compañía. El elemento tecnológico, la investigación documental acerca del dolor corporal, el dolor del alma y el dolor social, las personas con capacidades diferentes y la apropiación de la técnica Royhart, así como la adición de un sistema 
de tatuaje en vivo, hizo de este proyecto un largo y demandante proceso, pero con buenos resultados de todos en el equipo.

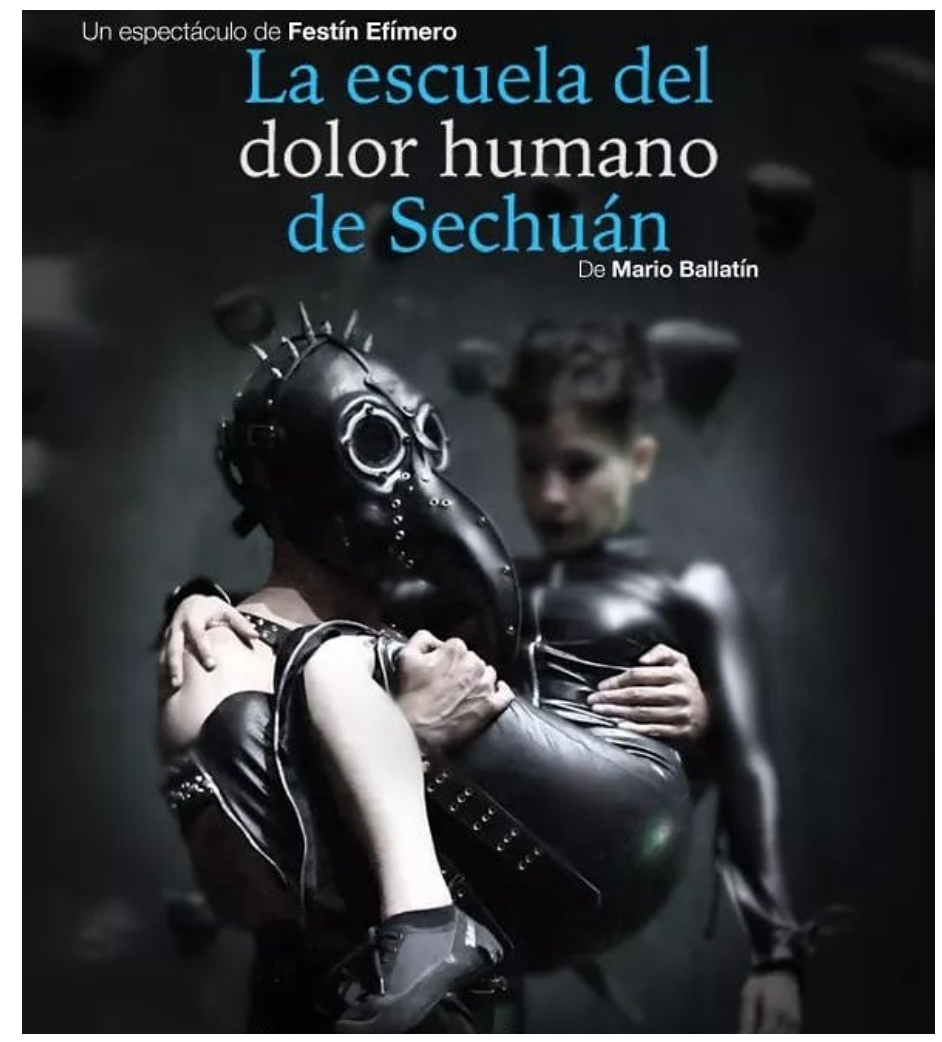

Foto 55. Publicidad de La escuela del dolor Humano.

Una vez más hicimos uso del entrenamiento que hemos venido haciendo como compañía, así como las herramientas adquiridas en las aulas y el lenguaje corporal en común de todos los participantes del grupo puede llegar a resultados estéticos y discursivos que impactan al público y forjan en el grupo una forma muy particular de abordar la escena actual.

Foto 56. Promoción en redes de La escuela del dolor humano.

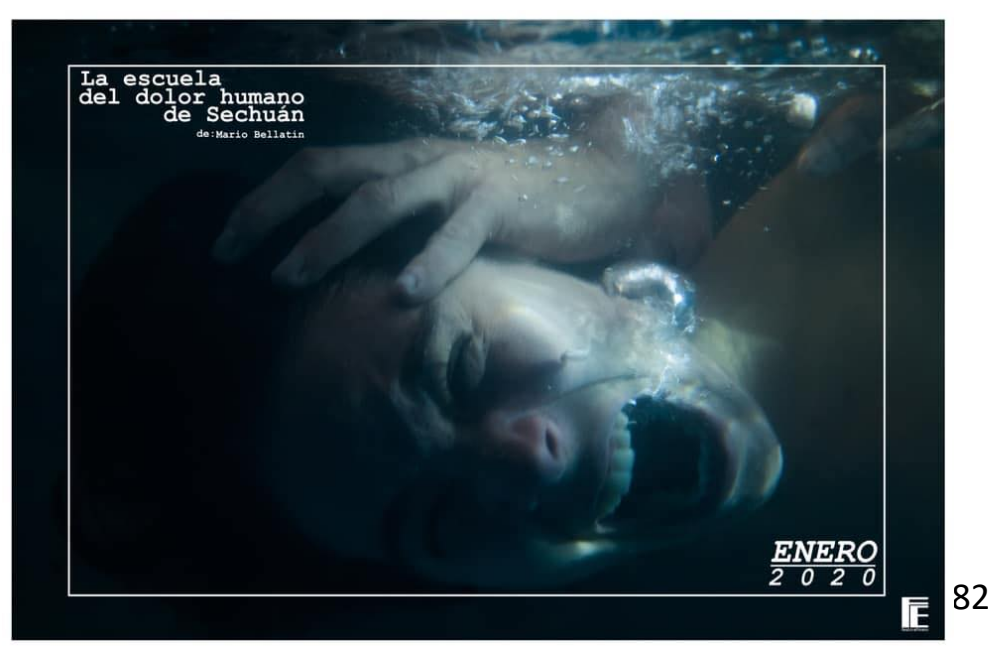




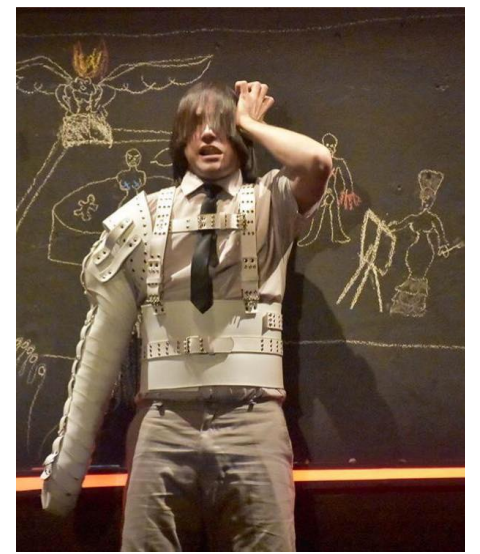

Foto $57 .{ }^{37}$

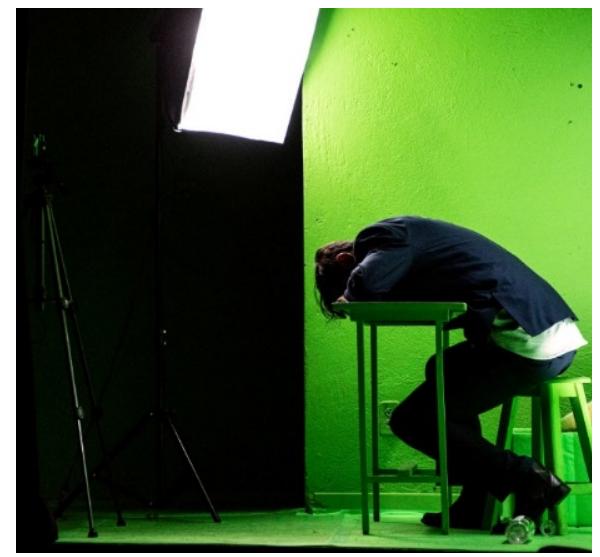

Foto 58.

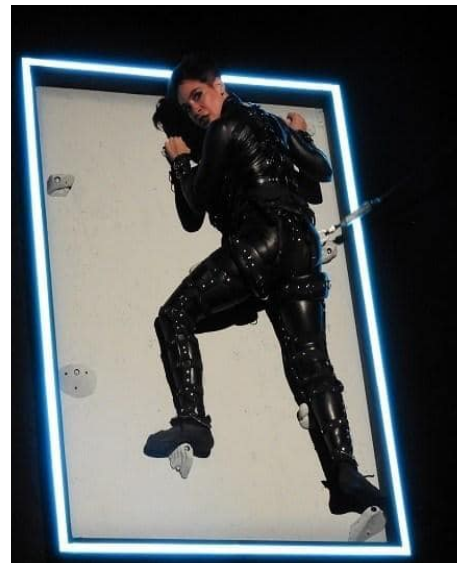

Foto 59.

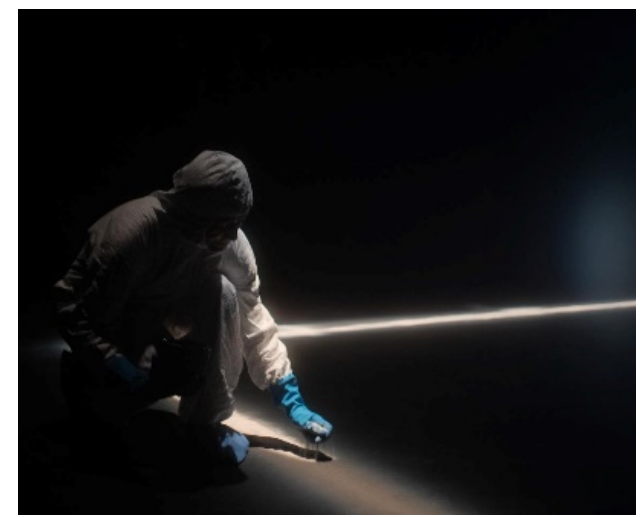

Foto 60 .

\subsection{El pedagogo / investigador que surca los aires}

La llegada de nuevos profesores y los cambios en la metodología de enseñanza del entrenamiento acrobático han impactado los resultados. En entrevistas y cuestionarios con egresados de CUT que experimentaron la transición en la asignatura, se observó una especie de alivio. Informan que hubo una mayor comprensión del motivo de la formación y se generó una empatía por la clase, que ha repercutido en su trabajo en el ámbito profesional.

\footnotetext{
${ }^{37}$ Fotos 57 a 60. Escenas de La escuela del dolor humano.
} 
En un fragmento da entrevista, a ex alumna Paulina Álvarez, actriz, 25 años cita:

Al estar en el montaje de la obra, me di cuenta que al abordar una de las escenas sentía la misma sensación que tenía cuando iba a realizar un salto de gran dificultad, lo cual me dispersaba. Me ponía nerviosa y constantemente fallaba al ensayar esa escena y no poder hacer lo que el director necesitaba. Cuando me di cuenta de eso, recordé que es lo que me hizo lograr el salto todas las ocasiones que lo pude conseguir: concentrarme, tener la técnica bien aprendida, enfocar mi energía y lanzarme a la ejecución. Eso mismo lo aplique para realizar la escena que me daba dificultades y pude lograr lo que el director necesitaba que hiciera.

El ex alumno Hugo Arrevillaga, actor y director, 45 años, cita:

Cuando sé que los actores que dirijo son del CUT, uso mucho las metáforas de la clase de acrobacia, ya que ejemplifican perfectamente lo que necesito que los actores sientan y expresen en sus cuerpos a la hora de estar en escena. Por lo general no uso los ejercicios acrobáticos en escena, pero la alerta, disposición y energía que debe de tener el cuerpo es comparable a la que debe tener alguien cuando va a realizar una ejecución acrobática de alto grado de dificultad. Cuando trabajo con actores que no vienen de ese tipo de formación es más difícil para ellos entender esas metáforas que tienen que ver con el riesgo, el arrojo, la concentración de un cuerpo que está en pleno vuelo, lo cual, en algunas ocasiones, además de ser cuerpos menos expresivos y energéticos, son cuerpos que no han pasado por esa experiencia y no pueden llevarla a escena.

El ex alumno Diego Jáuregui, actor 62 años, cita:

Nunca he utilizado la acrobacia como tal en escena en algún montaje me pidieron hacer ruedas de carro y las pude hacer, pero de ahí en fuera solo eso respecto a ejecución, pero todo lo demás que me dejo la clase como: disciplina, arrojo, concentración, conciencia corporal, mantenimiento de mi cuerpo entre otras, me ha ayudado en toda mi carrera profesional.

En múltiples pláticas y entrevistas puedo corroborar que la cantidad de montajes en los que se utiliza la ejecución de la acrobacia son pocos hoy en día; 
así que la utilidad que se le podía dar a esa herramienta no es la misma que se le dio en los años setenta y ochenta donde gran número de espectáculos requerían la ejecución acrobática como parte de sus herramientas a utilizar.

Ahora la herramienta acrobática he podido comprobar que va más encaminada a metáfora en escena, que creo que es lo que los maestros a principio de siglo y en los subsecuentes años buscaban, como lo había mencionado Grotowski y Barba en citas anteriores.

Hoy en día esta herramienta es más utilizada por personas que integran la comunidad teatral para poder entender desde la sensación del cuerpo la actuación y la disposición de este en escena. Más que dar saltos y piruetas, creo que lo que queda tatuado en el cuerpo y en su inconsciente son sensaciones que a través de la conciencia de haber pasado por la ejecución, puede transformar en herramientas útiles para la escena en un montaje.

Las nuevas teatralidades nos exigen, como intérpretes, tener un abanico mucho más grande de posibilidades. En México nos topamos cada vez más con proyectos que requieren tener a grandes conocedores se sus instrumentos físico, vocal, analítico e intelectual, para satisfacer las necesidades de los montajes, tanto experimentales como comerciales.

Se puede pensar que las personas que toman esta disciplina, terminan actuando de manera similar, lo cual no es posible. Aunque en alguna época de la clase se buscaba erróneamente la homogenización de las habilidades físicas, pocas veces se llegaba a lograr, dado que los estudiantes contaban con historias corporales y de vida demasiado distintas, y aunque algunos cuerpos llegaban a concretar un número importante de herramientas, a la hora de estar en el escenario no se podría decir que actoralmente eran similares.

La clase te dota de herramientas, y cada uno de los que integran la clase interpretara y aplicara esos materiales según lo que le ayude a ser mejor en su quehacer artístico. 
El cambio en la metodología de entrenamiento trajo otras perspectivas en la evaluación del aprendizaje. Los 'estándares de rendimiento' anteriores no aportaron nada pedagógico a la clase, porque se basaban solo en lo bueno / malo hecho. Si realizabas los ejercicios de manera correcta según la técnica eras bueno y sacabas una buena calificación, a pesar de que tal vez nunca analizaban nada más allá de la ejecución. Además de que la historia corporal del alumnado que podían realizar los ejercicios generalmente ya contaba con entrenamiento previo en otras disciplinas. Por otro lado si realizaban mal los ejercicios o si el tiempo de aprender a realizarlos era excesivo, se les consideraban de bajo aprovechamiento y sacaban mala calificación, nunca se tomaba en cuenta la historia corporal o los logros que se llegaban a concretar después de mucho tiempo de entrenamiento.

Dadas estas circunstancias se decidió desde hace varios años no tomar en cuenta estos estándares.

Al llevar un entrenamiento individualizado, así como la historia corporal de cada persona y toda la información que ahora es requerida para conocerlos mejor, nos concretamos a los logros personales y al aprendizaje de la técnica de manera individual.

Exigiendo a quien sabemos que puede seguir avanzando y acompañando a quien pueda por diferentes circunstancias llevar el aprendizaje a otro ritmo. Nunca dejando a nadie en el camino y tampoco permitiendo que entren en una zona de confort donde se estanque su trabajo.

Para esto se tiene que tener una empatía con los integrantes de la clase y conocerlos, para generar esa confianza y puedan siempre exigirse más, cuidando su cuerpo y cuidando a sus compañeros. 
Se trata de mi cuerpo al que bendigo, contra el que lucho, el que ha de darme todo en un silencio robusto y el que se muere y mata a menudo.

Jaime Sabines 


\section{CAPITULO 4}

Los nuevos enfoques, objetivos y metodologías del entrenamiento físico en el CUT.

Después de reflexionar sobre todo lo que implica las clases de acondicionamiento físico y acrobacia en el CUT, su historia, su evolución a través de los años, el cambio de maestros y sobre todo el cambio generacional, podemos darnos cuenta que es momento de hacer una mudanza en la forma de impartir estas materias.

Por eso hago las siguientes observaciones y sugerencias generar los cambios que se necesiten en la impartición de estas materias, los cuales algunos se han empezado a aplicar desde hace dos años, y otros espero se puedan ir sumando al cambio radical que debe sufrir estas clases.

- Pasar de una tradición de 44 años, a un enfoque más pedagógico, en pro de la actuación y no en pro de la ejecución de suertes circenses.

- Saltar de un intento por homogenizar cuerpos, a una realidad generacional que nos obliga a individualizar el entrenamiento.

- Transformar el objetivo de lograr metas, a transitar por los procesos para analizar la experiencia vivida y como esta ayudaran en el futuro artístico del estudiante.

- Dejar de obligar, para pasar a invitar y motivar.

- Poner como premisa la seguridad, generar empatía, confianza y libertad para poder explorar el arrojo, el riesgo, el vértigo, la energía, la concentración, el fracaso, el logro, el miedo, la adrenalina, el trabajo en equipo, la confianza, y todo lo que funcione como herramientas útiles para la actuación. 
- Deshacerse de viejas prácticas no pedagógicas que ponderaban el entrenamiento deportivo sobre el actoral, así como sustituir ejercicios de alto riesgo y alto impacto por ejercicios que generen el mismo efecto en el cuerpo del alumnado, pero sin poner en riesgo la integridad física y mental.

- Revisar material teórico sobre el funcionamiento del cuerpo humano, psicología del entrenamiento, teoría y metodología del entrenamiento, así como de distintos autores que hablan sobre la relación del cuerpo y la actuación. Análisis que pocas veces ocurría en este tipo de clases.

- Remover el nombre de acondicionamiento físico, acrobacia I II III y IV para solo llamarlo entrenamiento físico o entrenamiento corporal.

- Invitar a especialistas (nutriólogos, psicólogos, médicos del deporte, etc.) a hacer revisiones periódicas de la salud corporal y mental de los estudiantes, así como responder dudas que se tengan respecto al cuerpo.

- Entablar un diálogo con todos los que formamos parte de la clase antes de iniciarla, para preguntar a los estudiantes sobre: horas de sueño, padecimientos físicos, enfermedades y alimentos injeridos previos a la clase, con el fin de descansar a las personas que no se encuentren en condiciones alimenticias o de sueño para la realización de ejercicios.

- Revisión periódica del material de enseñanza, con el fin de actualizar constantemente las metodologías y ejercicios a ejecutar, con el fin de no estancarse en un solo método o forma de compartir el aprendizaje.

- Actualización constante de los docentes que imparten las clases corporales, tanto en lo laboral, la investigación y la generación de análisis sobre el entrenamiento. 


\subsection{Propuesta de nuevos planes de estudio}

Se plantea este primer esbozo de los planes de estudio y sus objetivos:

Entrenamiento físico I (Antes acondicionamiento físico)

El acondicionamiento físico permitirá revelar a los alumnos y alumnas con que instrumento cuenta a su llegada al CUT para su trabajo escénico.

Descubrirá a profundidad composición, funciones, cuidados, etc. De sus órganos, sistema óseo y sistema muscular (músculos, tendones, ligamentos, etc.) Con lo cual entenderá la importancia de conocerse a sí mismo, sus límites y áreas de oportunidad a trabajar.

Conocerá los distintos sistemas energéticos y su funcionamiento, los cuales son de suma importancia para saber cómo generar, almacenar y detonar la energía requerida en escena.

Sabrá los distintos tipos de lesiones y cómo prevenirlas, para que su rendimiento nunca tenga que ser frenado por un accidente, y en caso de sufrir algún percance conocer la gravedad del mismo, tiempo de descanso y rehabilitación para no volver el incidente una lesión crónica que afecte su rendimiento sobre la escena a futuro.

Seleccionara los ejercicios con los cuales elaborara el calentamiento que ayude a que su cuerpo cuente con una disposición al trabajo escénico.

En este primer año se desarrollaran las condicionales físicas: ejercicios físicos de fuerza, resistencia a la fuerza, flexo elasticidad, velocidad, equilibrio, atención y coordinación para que el alumno o alumna logre una estructura corporal más dúctil y expresiva.

Se abordara el entrenamiento según las características físicas individuales de cada individuo, dividiendo el entrenamiento según las posibilidades y avance de cada uno, nunca presionando a la realización de ejercicios en los que las personas no se sientan listo física y mentalmente. 
Durante el primer ciclo se priorizara el conocimiento del cuerpo, su trasformación individualizada y el óptimo estado físico, psíquico y emocional para su desarrollo corporal en las distintas materias durante la licenciatura.

El alumnado debe ser capaz de:

a) Reconocer la composición de su cuerpo, habilidades físicas (fuerza, resistencia, velocidad, flexo, elasticidad) y fomentar la superación de las mismas al ritmo que los que integran la clase sienta cómodo pero fuera de su zona de conforto.

b) Identificar áreas de oportunidad en su cuerpo a trabajar, para lograr su desarrollo y poder coordinar la ejecución de ejercicios por aprender.

c) Generar procedimientos personales para su entrenamiento, tomando en cuenta la relación del cuerpo con el espacio, tiempo, ritmo y acompañamiento, elementos principales en su quehacer escénico.

d) Aprender sobre las consecuencias de la falta de disciplina, desconcentración, falta de sueño, mala alimentación y comparación con otros integrantes de la clase, con el fin de no caer en prácticas que desfavorezcan su desarrollo corporal.

e) Ser capaz de identificar los mecanismos que generan la energía a nivel fisiológico, como se controlan, se retiene y se diluyen para su uso en las distintas materias de la licenciatura.

: Es el inicio del aprendizaje corporal, generador de autoconocimiento para el actor y la actriz en formación.

Entrenamiento físico II (Antes acrobacia I y II)

El conocimiento y la suma de nuevos ejercicios de entrenamiento físico basados en las condicionantes físicas, el equilibrio y la acrobacia, constituyen la continuidad del entrenamiento físico I y desarrolla ejercicios que nos retan a llevar más allá los límites físicos y mentales que se tienen hasta el momento. 
No se trata de crear acróbatas que puedan hacer ejecuciones circenses en escena, se abordan algunos ejercicios acrobáticos de impulso y equilibrio, que son seguros pero que desafían y ponen en juego todos los elementos trabajados previamente, así como la suma de nuevas sensaciones que se entrecruzan con la actuación, como la concentración, la sincronización, el arrojo, el miedo, el riesgo, entre otras.

El proceso y análisis de la ejecución tiene más peso que la ejecución en sí, no importa si la ejecución es buena o mala, ya que no somos deportistas, el camino por el que pasa el cuerpo y la mente para llegar a la ejecución es lo más importante, al igual que las metáforas y analogías que podamos hacer entre miembros de la clase con relación al trabajo actoral.

Las habilidades que se adquieren son más psíquicas que físicas, dado que privilegiamos más la observación de la ejecución, lo que provoca y desafía a nuestra fuerza mental, para poder lograr completar un ejercicio. Damos menos atención a la realización en sí, pero siempre acompañamos al alumnado a su ritmo y fomentando un enfoque lúdico.

El riesgo implica concentración y atención del ejecutante y de todo su grupo, aunque no se esté realizando el ejercicio, se genera apoyo y empatía con el alumno y alumna en turno por parte de su grupo, elemento que también encontramos al estar en escena.

El nuevo enfoque que se le da a la clase de acrobacia beneficia directamente al desarrollo de la presencia escénica del estudiante, dado que habita en él una conciencia corporal extra cotidiana, así como elementos físicos y mentales que solo pueden ser conocidos al experimentar cierta clase de ejercicios de manera segura y con un cuerpo que ha desarrollado conocimiento sobre sí mismo.

El alumnado será capaz de:

a) Darle continuidad al siguiente nivel de trabajo en el entrenamiento físico para generar nuevos impulsos y control para ejecutar los distintos ejercicios corporales. 
b) Ser capaz de analizar los ejercicios para relacionar los dispositivos energéticos, metáforas y analogías que se entrecruzan con otras clases, en especial la actuación.

c) Navegar por el descontrol de su cuerpo y todas las sensaciones que esto genera, seguro de que no sufrirá daños a su integridad física o su salud, en pro de encontrar los mecanismos que lo acerquen al control físico y mental del ejercicio.

d) Sentirse preparado para integrar elementos externos con seguridad, como otros cuerpos, obstáculos y aparatos gimnásticos que maximizan las ejecuciones para descubrir nuevas sensaciones y retos personales.

e) Aprender a convivir con el riesgo, el vértigo, el arrojo, la adrenalina, el miedo, la resistencia, el obstáculo, la euforia, el fracaso, la frustración, el impulso, la energía, el control, etc. Elementos que encontramos en tanto en los ejercicios acrobáticos como en la escena.

: El cuerpo desafiando la gravedad, estudiantes descubriendo sus alas.

Entrenamiento físico III (Antes Acrobacia III y IV)

Esto consta del desarrollo del Entrenamiento físico II, el cual estará basado en ejercicios que otorgan al alumno las herramientas que lo ayudan a avanzar a otro nivel, de forma individual, para un manejo y control de cuerpo y mente, en beneficio de su proceso físico actoral.

Todas las sensaciones exploradas en los ejercicios previos, se verán exacerbadas con el descubrimiento de ejercicios de mayor grado de dificultad, que generen nuevos análisis y analogías con la actuación, siempre privilegiando la seguridad y la individualización del entrenamiento.

Se fomenta un trabajo totalmente individual y acorde con las necesidades de cada alumno por explorar y desafiarse a sí mismo en los ejercicios, siempre acompañado del maestro o maestra para realizar el análisis que cada elemento implica. 
Se aplicaran y fortalecerán todos los conocimientos adquiridos en Entrenamiento físico I y II, para evolucionar a sensaciones más extremas que detonen en el alumno escenarios posibles donde el cuerpo y la mente tienen que estar preparados para reaccionar, tal y como lo exige la escena.

Se aumenta el nivel de análisis corporal y decrece el porcentaje de ejecución con vistas a potenciar el trabajo mental, psíquico y analítico respecto al cuerpo, se deja atrás el solo saber ejecutar suertes acrobáticas para su uso en escena.

Se crea, de manera consiente en el alumno, un conocimiento sobre su cuerpo y las sensaciones que los impulsos generan en él, la exploración, tránsito y aterrizaje de los ejercicios, así como su análisis y estudio serán herramientas de las cuales podrá echar mano en su quehacer artístico.

El alumnado debe ser capaz de:

a) Conocer a detalle su instrumento de trabajo, sus alcances y límites para poder explorar los distintos ejercicios que lo lleven a descubrir las metáforas y analogías con la actuación.

b) Saber navegar por el descontrol, la emoción, la tensión, las resistencias y el miedo para llegar a un estado óptimo de inicio, desarrollo y fin de las ejecuciones de los ejercicios, para salvaguardar su integridad física y hacer el análisis que lo lleve a crear herramientas útiles del vuelo realizado.

c) Encontrar los mecanismos generadores, acumuladores y detonadores de energía para su uso en los ejercidos, así como en otras disciplinas y en su vida artística futura.

d) Perfeccionar un calentamiento musculo esquelético con todo el conocimiento adquirido, que le permita estar listo y dispuesto fisca y mentalmente, no solo para la clase, si no para cualquier ejercicio actoral o puesta en escena.

e) Ser capaces de velar por la seguridad propia y de sus compañeros gracias al conocimiento y análisis de los ejercicios, así como la generación de empatía grupal y apoyo entre el alumnado.

f) Transitar por los ejercicios que cada uno decida explorar, sin temor a poner en riesgo su integridad física o salud. 
: El vuelo libre del actor y la actriz en formación, conocerse a sí mismo para vencer el aire.

\subsection{La diversidad de los cuerpos.}

Unos de los temas que considero importantes resaltar de los nuevos enfoques que se pretenden implementar en las dinámicas de la clase de entrenamiento físico es la diversidad de los cuerpos.

En décadas anteriores, como se explica en otros capítulos, en esta clase siempre se buscaba tener cuerpos preparados o relativamente preparados para enfrentar cualquier desafío físico que exigía el nivel de entrenamiento en el CUT.

Con el paso de los años hemos sido testigos de cómo ha cambiado esta perspectiva, la cual ha hecho cambiar desde los métodos de selección de aspirantes hasta la forma de impartir el entrenamiento físico en las distintas materias.

Muchas de estas nuevas formas han surgido gracias al concepto de “Individualización del entrenamiento", también mencionado en capítulos anteriores, tener la capacidad como maestros y maestras de adaptar la enseñanza a cada cuerpo según su historia, sus características, sus limitantes y sus posibilidades es una tarea a la que se le debe poner especial atención.

Ya que anteriormente se buscaba un trabajo más deportivo y de ejecución, sin sumergirse demasiado en las profundidades del análisis físico-actoral-expresivo, el trabajo con los cuerpos con condicionantes físicas como: fuerza, resistencia, elasticidad, velocidad, etc. Resultaba más sencillo con cuerpos entrenados que con los cuerpos carentes de estas características.

Dando como resultado un abandono a la atención de los cuerpos diversos, y por lo tanto un desanimo, enojo y deserción por parte de los personas que cursaban la clase y que no podían llenar las expectativas de ejecución de los maestros anteriores. 
Desde mi llegada al CUT hasta el inicio de mi carrera como pedagogo, identifique la falta de atención a este tipo de alumnos y alumnas, decidí abordar esa problemática, ya que en muchas ocasiones no era falta de habilidad o que el cuerpo fuera un desastre, simplemente se ponía más atención a cuerpos que ejecutaran mejor los ejercicios y que no necesitaran tanto trabajo, repetición o esfuerzo para llegar al objetivos de aquellos años.

Curiosamente, cuerpo altamente entrenado y con una capacidad de ejecución de muy alto nivel carecían de otras herramientas al momento de realizar ejercicios de actuación, expresivos o estar en escena.

Y los cuerpos que no tenían tanta habilidad aparente, que padecían de alguna condición o carecían de las condicionantes físicas resultaban ser cuerpos expresivos, con presencia y listos para resolver cualquier reto escénico.

Lo cual hacia preguntarme ¿Cómo puedo lograr que los cuerpos con una historia corporal diferente, y a veces carentes de condicionantes físicas, puedan no solo realizar los ejercicios por realizarlos, sino lograr un análisis de las posibilidades expresivas personales? pensando en elementos básicos para la actuación como: generación y detonación de energía, concentración, enfoque, explosividad, impulso, entre otros

Fue ahí cuando la implementación de nuevas metodologías, objetivos y enfoques jugo un papel importante en las últimas generaciones, dado que al no buscar el resultado, sino privilegiar siempre el proceso y el análisis de cada cuerpo, se logra quitar presión al alumnado para concentrarnos en que cosas se convertirán en herramientas útiles para su formación.

Creo que en los últimos años no ha sido un factor de preocupación o algo que limite abordar el trabajo en clase con la generación de nuevo ingreso, todo lo que tiene que ver con su historia corporal: las lesiones, las enfermedades, los padecimientos, las complexiones, los cuerpos en transición (alumnos y alumnas transexuales), el sobrepeso, el consumo de medicamentos psiquiátricos, las dietas, lugar de crecimiento, actividades físicas de la infancia, entre muchas otras. 
Sin embargo se tienen en cuenta todas estas características de cada individuo, para no abordar ejercicios o entrenamientos que vayan a poner en riesgo la integridad o a bajar el rendimiento corporal del alumnado.

Esto se trata de no abordar desde la prohibición, sino desde la conciencia y el conocimiento de cada estudiante sobre su cuerpo, como se menciona en otro capítulo de la investigación, haciendo que se den cuenta de sus capacidades, sus limitantes y las áreas de oportunidad a trabajar.

Se podría presumir que cualquier cuerpo podría llevar acabo el entrenamiento físico que realizamos en clases, siempre ponderando la seguridad y haciendo un análisis profundo sobre la responsabilidad que tenemos sobre esos cuerpos, nunca arriesgando la salud física y mental de los estudiantes. 
Vengo de un largo trayecto de abandonos no soy la única lo sé no lo presumo pero son mis pies los míos los que recorren y recorrieron el camino mis pies y no otros mi cansancio y fatiga intemperie de abrazos sin consuelo ensimismada.

Esther Seligson 


\title{
CAPITULO 5
}

\section{El investigador en vuelo}

\subsection{Despegue y cielo abierto}

\begin{abstract}
Principio de incertidumbre
Si conocemos de forma muy precisa la posición de la partícula no podremos conocer de forma tan precisa su velocidad y viceversa independientemente de lo bueno que sea nuestro aparato de medida o de lo que nos esforcemos en ello. La incertidumbre en el sistema es intrínseca y no puede desaparecer nunca"38
\end{abstract}

El principio de incertidumbre es un concepto que aprendí mientras estudiaba ingeniería industrial, y que después de las reflexiones sobre esta investigación ha vuelto a mí.

Se han analizado muchos aspectos de la historia de la clase, los cambios a través de los años y los nuevos enfoques a los que apunta este entrenamiento, sin embargo no se puede saber de forma precisa si estas nuevas formas y metodologías vayan a funcionar en todo el espectro que abarcan.

Dado que las generaciones cambian año a año, al igual que sus necesidades y muchos aspectos de la pedagogía, creo que no podemos asegurar que los cambios sugeridos sean un cierre a la necesidad de seguir investigando, documentando o haciendo preguntas sobre la forma de entrenar los cuerpos de los futuros actores y actrices.

Creo que esta investigación es la apertura de una puerta para dar continuidad a la revisión, en cada nuevo periodo, de nuestros objetivos como pedagogos, a la implementación de nuevos conceptos, información y sobre todo análisis de nuestra forma de impartir la acrobacia dentro del entrenamiento físico, así como sus cruces con la clase de actuación en el CUT.

Hay dos conceptos, los cuales descubrí rumbo al final de la investigación, los cuales me abren un panorama amplio de continuidad de esta primera exploración; la artificialidad y la organicidad.

\footnotetext{
38 https://culturacientifica.com/2020/01/21/el-principio-de-incertidumbre/
} 
En un artículo de Leela Alaniz ${ }^{39}$ en la revista Cena ${ }^{40}$, capto mi atención el análisis que hace sobre la relación del trabajo de Decroux con la definición de Grotowski del linaje artificial. La definición de la artificialidad como la forma de la emoción, además de entrecruzarse con muchas artes escénicas orientales relacionadas con este término.

Muchas de las características de las artes orientales, como el Kathakali de India, el No de Japón o la ópera de Pekín, prestan atención a la importancia de la observación, por parte de los alumnos, de las acciones que realizan los profesores. A través de la imitación y el duro entrenamiento, los jóvenes actores aprenden su oficio durante varios años y continuarán por el resto de sus vidas.

Lo cual invariablemente me lleva a pensar en el tipo de entrenamiento que realizamos en el CUT en las clases de acrobacia, ya que los cuerpos que se entrenan con estas herramientas buscan, a través de los ejercicios, investigar sobre la expresividad, para que después sea abordada en su quehacer actoral.

Esa artificialidad, como se menciona en el artículo, es la forma que encerrara la emoción, y relaciono mucho como el movimiento del cuerpo va ligado con el movimiento de la mente.

Siempre la búsqueda del vértigo, el equilibrio precario, el desafío a la gravedad, el peligro y todos los movimientos antinaturales que se realizan en la acrobacia formaran sensaciones, imágenes, estados de ánimo y un mapeo mental que después podremos usar como estudiantes en formación o como artistas profesionales.

El alumno no debe simplemente imitar la forma exterior, sino que debe penetrar la esencia de una figura o un movimiento para descubrir los impulsos de los que fluyen los 'movimientos' enfriando la emoción que se traduce por la técnica, con el fin de crear una expresión impersonal de una emoción o idea universal. ${ }^{41}$

\footnotetext{
${ }^{39}$ Actriz franco-brasileña y directora artística de la compañía de teatro Pas de Dieux, con sede en París, investigadora en Antropología Teatral y Mimo Corporal.

${ }^{40}$ https://seer.ufrgs.br/cena/article/view/72761

${ }^{41}$ Ibidem.
} 
Al hacer las relaciones con las artes escénicas orientales, también observo una diferencia con nuestro enfoque de entrenamiento en el CUT. En las artes orientales se hace este trabajo con un fin escénico, en donde todo el aprendizaje y entrenamiento de años es vertido en el espectáculo.

En cambio, en el entrenamiento que hacemos en el aula el fin es pedagógico, lo cual no quiere decir que vayamos a usar estos ejercicios para la escena, sino que nos invita a desentrañarlos para analizar lo que provocan en los estudiantes y como ya se dijo antes, formular las metáforas y analogías con nuestra profesión.

Lo que hace que el cuerpo del alumnado logre un instrumento libre, expresivo y que pueda contener toda la presencia, energía, emotividad y organicidad que requiere para desarrollarse actoralmente en lo profesional.

Me pregunto ¿Podría estar ligada la acrobacia al linaje de lo artificial que define Grotowski?

No tengo la respuesta, necesitaría sumergirme en otra investigación para saber cómo la acrobacia se relaciona con el linaje de lo artificial, pero me abre un cielo bástate amplio para explorar y me surgen más preguntas como:

¿Qué camino podemos seguir para poder llegar a la organicidad desde lo artificial? ¿Cómo se relaciona la acrobacia con las artes orientales? ¿Existe un método o alguna hipótesis para relacionar los caminos de lo orgánico y lo artificial? ¿Permite nuestra practica acrobática relacionar esos caminos de forma consiente? ¿Se relaciona la artificialidad con los métodos que se usaban antes para la enseñanza de la clase en el CUT?

Creo que son preguntas importantes que valdría la pena investigar y aclara para tener más luz en este camino, esto me arroja que hay un sin número de posibilidades para abordar otro trabajo de investigación que puede seguir nutriendo la forma de dar clases de estas materias en el CUT.

Regresando al concepto del principio teórico antes mencionado, principio de incertidumbre, puedo comprobar que esta investigación es apenas el principio de un mundo de opciones para entender el entrenamiento físico. 
Ya que en cuanto se tiene un panorama de ciertos conocimientos, surgen muchos otros conceptos, estudios, teorías, artículos, hipótesis, etc. Que nos generan nuevas preguntas y suman al conocimiento de la práctica que realizamos.

Al igual que en principio de incertidumbre, si conocemos la posición exacta de una partícula nunca podremos saber a ciencia cierta su velocidad y viceversa. 
El entrenamiento no es para tres años, es para toda la vida42 Jurij Alschitz

${ }^{42}$ ALSCHITZ Jurij, Entrenamiento para siempre, Universidad Nacional Autónoma de México, México DF. 2013. 


\section{CONCLUSIONES}

\section{Primeras conclusiones de la investigación como:}

\section{Exalumno - Artista - Pedagogo - Investigador}

Lo que me detona la frase de la página anterior, es algo que he logrado comprender a través de esta investigación. El cuerpo siempre estará en entrenamiento constante de una manera u otra, no solo tres años de clases, aunque nuestro cuerpo cada vez sea menos capaz de ejecutar ciertas técnicas o ciertos movimientos debido a su desgaste natural.

Pero lo qué hacen que el tipo de entrenamiento que realizamos durante tres años se quede para toda la vida es precisamente el que no sea un entrenamiento sobre la ejecución, o puramente físico; sino también psíquico, analítico e intelectual y el cómo operar esa información para poder después manejarla en otros escenarios posibles, como el de la puesta en escena.

Si nuestra intención como docentes o artistas fuera entrenar con un objetivo similar al deportista nuestra vida útil sería muy corta.

Algo como lo que pasa con los gimnastas cuya vida deportiva útil es de apenas un par de años.

Nosotros los actores y las actrices podemos presumir de vidas laborales longevas, aunque nuestros cuerpos pudieran no ser los mismos instrumentos entrenados de cuando estuvimos en la universidad, el entrenamiento se quedará para siempre con nosotros, ya que son herramientas conscientes que siempre nos ayudarán a la hora de pisar un escenario.

Tal vez el objetivo de la clase de acrobacia, en sus primeros años de existencia, fue el de crear artistas capaces de ejecutar piruetas en los escenarios, y para la institución resultaba novedoso e importante dotar a sus egresados de esta herramienta para poder realizar esa clase de ejercicios circenses en puestas en escena. 
Ahora con el paso de los años, los cambio de paradigmas y enfoques en la clase de entrenamiento físico, se puede asegurar que se cuenta con personas más conscientes de sus cuerpos y sus emociones, qué saben qué este tipo de entrenamiento es una herramienta más a la hora de abordar un personaje, una escena, un montaje o actuar en los distintos lenguajes actorales.

Seres que conocen muchos elementos de su instrumento de trabajo, desde cómo está compuesto, funcionamiento de los sistemas energéticos, concientización de factores intangibles como el arrojo, la concentración, el miedo, etc. Hasta metodologías de preparación del cuerpo para la escena.

Con lo cual espero contestar la pregunta que me planteaba en el principio de esta investigación ¿Este tipo de entrenamiento físico sigue siendo útil para los estudiantes del CUT?

Opino que puede ser útil, si se dejan de seguir las prácticas empíricas adoptadas hace muchos años, se necesita hacer un replanteamiento a profundidad de muchos aspectos y hacer un cambio radical en la forma de impartir el entrenamiento físico en la actualidad, desde sus objetivos, pasando por los enfoques de sus ejercicios y hasta las metodologías de trabajo.

También considero que el replanteamiento del tipo de entrenamiento físico que se lleva a cabo en el CUT, debe obedecer a las necesidades de sus estudiantes, adaptarse a las diferencias generacionales y características que cada grupo trae consigo.

Creo que el entrenamiento físico nunca caducara en la formación de actores y actrices, es necesario, dado que el cuerpo es uno de los elementos más importantes para artista, es su instrumento de trabajo, conocerlo a fondo puede ser una herramienta muy útil para quien inicia sus estudios de actuación, dadas las exigencias vocales, emotivas, corporales y estéticas de los montajes actuales en la escena mexicana.

Con esta primera investigación pretendo contribuir al cambio radical en la forma de impartir la clase, además de la revisión y cambio de los planes de estudios del CUT, de la mano se sus directivos y especialistas en la materia, tomando en cuenta las necesidades de los alumnos y alumnas, conservando los pilares aún 
vigentes de estas clases como disciplina, tenacidad y juego, elementos importantes para cualquier artista en formación.

Espero que se pueda revisar en unos años los cuestionamientos hechos en esta investigación y hacer los cambios necesarios para que las clases de entrenamiento físico sigan evolucionando para bien del alumnado.

Ya que es sumamente necesario que se esté indagando y nos estemos examinando continuamente, para descubrir qué cambios podemos hacer en beneficio de las nuevas generaciones, nuevas prácticas, nuevas necesidades del teatro y la actuación en México.

De ese modo, no volver a caer en los errores que posiblemente se cometieron en el pasado, como: nunca cuestionarse, no investigar, asumir que el tipo de entrenamiento y la metodología de enseñanza funcionaban para todos, no escuchar a los estudiantes, no analizar las cargas de trabajo, no revisar los planes de estudios, entre otros.

De igual manera espero despertar en otros la curiosidad por investigar sobre la aplicación pedagógicas en las distintas técnicas enfocadas al cuerpo, ya que, como lo he mencionado antes, es un terreno inhóspito en este país, creo que podría ser muy benéfico, tanto para los actores y actrices en formación como para los profesionales, contar con personas interesadas en cuestionar y sumergirse en el mundo de la investigación.

Por último, espero poder seguir haciéndome preguntas, sobre los objetivos, enfoques, metodologías, etc. Con cada nueva generación del CUT, con cada nuevo proyecto de mi compañía y con cada incursión a los distintos lenguajes actorales.

Ya que una vez que inicias la carrera como investigador, no puedes parar, necesitas ir más allá, responder más preguntas, volar sobre mundos que no han sido explorados, surcar cielos por los que no hemos planeado, trazar mapas que no existen aún y formar una perspectiva diferente de la apreciación del mundo.

Gracias a esta experiencia espero seguir mi vuelo como investigador. 
¿Con qué he de irme? ¿Nada dejaré en pos de mí sobre la tierra? ¿Cómo ha de actuar mi corazón? ¿Acaso en vano venimos a vivir, a brotar sobre la tierra? Dejemos al menos flores Dejemos al menos cantos

Nezahualcoyotl 
Bibliografía

ALSCHITZ Jurij. Entrenamiento para siempre. Universidad Nacional Autónoma de México, México, DF, 2013.

BARBA Eugenio. El arte secreto del actor. Escenologia A.C. México DF. 1990.

BASTOS, Helena. Cuerpo sin voluntad. Cooperativa Paulista de Dança, São Paulo, 2017.

CEBALLOS, Edgar. Ética y disciplina / método de las acciones físicas. Escenología A.C. México DF. 1994.

. El actor sobre la escena / Meyerhold. Escenologia A.C. México

DF. 1998.

HERRIGEL, Eugen. El zen del arte del tiro con arco. Editorial Kier, México DF. 1999.

MULLER, Carol. El training del actor, Universidad Nacional Autónoma de México, México DF. 2007.

REVISTA MASCARA. Los juegos, Grotowsky. Escenología A.C México DF. 1992.

RUIZ, Borja. El arte del actor en el siglo XX. Artezblai SL, México DF. 2008.

SERBULO Mayra. Manual de entrenamiento físico sensible. Edigrafica, CDMX. 2017.

STANISLAVSKI, Konstantín. Manual del actor. Editorial Diana, México DF. 1977. 
tomo, México DF. 2013.

Otras referencias:

www.cutunam.com.mx

www.efdeportes.es

https://psicologia.laguia2000.com

https://culturacientifica.com

https://seer.ufrgs.br

Entrevistas:

Paulina Álvarez, actriz, 25 años.

Hugo Arrevillaga, director y actor, 45 años.

Diego Jauregui, actor, 62 años.

Raul Kaluriz, acróbata, 78 años.

Mayra Serbulo, actriz y profesora, 50 años.

Mario Espinosa, director, 62 años. 